\title{
REGULAÇÃO DAS MICROFINANÇAS NO BRASIL: \\ ARCABOUÇO INSTITUCIONAL E ARTICULAÇÃO \\ A POLÍTICAS PÚBLICAS DE SUPERAÇÃO DA POBREZA
}

\begin{abstract}
Dissertação apresentada à Faculdade de Direito da Universidade de São Paulo, sob a orientação do Prof. Dr. Diogo Rosenthal Coutinho, como requisito parcial para a obtenção do título de mestre em Direito Econômico e Financeiro.
\end{abstract}

Candidata: Juliana Nogueira Marques

\author{
Universidade de São Paulo \\ Faculdade de Direito \\ Departamento de Direito Econômico e Financeiro
}

São Paulo, fevereiro de 2009. 
Banca Examinadora 


\section{SUMÁRIO}

Agradecimentos $\quad 4$

Considerações Preliminares 6

1. As microfinanças: seus conceitos, panorama institucional e arcabouço 12 normativo

$\begin{array}{ll}1.1 \text { Introdução } & 12\end{array}$

$\begin{array}{ll}\text { 1.2 Microfinanças para quem? O público-alvo. } & 17\end{array}$

1.3 Microfinanças por quem? O panorama institucional. 20

a) Antecedentes do marco regulatório das microfinanças 23

b) Arcabouço regulatório das microfinanças no Brasil 29

c) Sumário da evolução normativa e institucional 39

$\begin{array}{ll}1.4 \text { Dilemas e debates } & 43\end{array}$

2. A prestação de serviços microfinanceiros no Brasil 46

2.1 Introdução 46

2.2 Disciplina jurídica da prestação de serviços microfinanceiros 46

a) Instituições sob regulação e fiscalização no âmbito do Sistema 46

Financeiro Nacional

a.1) Instituições financeiras privadas $\quad 47$

a.2) Sociedades de Crédito ao Microempreendedor (SCM) $\quad 50$

a.3) Instituições financeiras públicas 53

a.4) Cooperativas de crédito $\quad 60$

b) Instituições não reguladas ou não supervisionadas no âmbito do 60

Sistema Financeiro Nacional

b.1) Organizações Não-Governamentais e Organizações

da Sociedade Civil de Interesse Público

b.2) Bancos do Povo 65

$\begin{array}{ll}2.3 \text { Quadro geral da demanda por serviços microfinanceiros } & 67\end{array}$

$\begin{array}{ll}2.4 \text { Oferta de serviços microfinanceiros } & 68\end{array}$

a) Bancos privados e sociedades de crédito ao microempreendedor $\quad 71$

b) Organizações Não-Governamentais e Organizações da Sociedade 72

Civil de Interesse Público

c) Bancos públicos e Programa CrediAmigo

d) Cooperativas de crédito $\quad 76$

$\begin{array}{ll}2.5 \text { Debates e dilemas } & 78\end{array}$ 
3. Microfinanças \& Políticas Públicas

$\begin{array}{ll}3.1 \text { Introdução } & 81\end{array}$

3.2 Atuação concertada dos atores que formulam e executam políticas $\quad 81$

3.3 Arcabouço institucional do PNMPO

a) Estrutura e metodologia $\quad 84$

b) Desempenho 86

c) Papel do BNDES no PNMPO 87

d) Projetos e parcerias $\quad 89$

3.4 Articulação das microfinanças a políticas públicas de superação da pobreza 90

Considerações Finais $\quad 93$

$\begin{array}{ll}\text { Abstract } & 96\end{array}$

$\begin{array}{ll}\text { Bibliografia } & 97\end{array}$ 


\section{AGRADECIMENTOS}

Sou grata à Fundação de Amparo à Pesquisa - FAPESP, pelo apoio financeiro, e ao seu parecerista $a d$ hoc, pelas oportunas críticas e sugestões realizadas durante a vigência da bolsa.

Na Faculdade de Direito do Largo São Francisco contei com o apoio inestimável de meu orientador, Prof. Dr. Diogo Rosenthal Coutinho. Sob sua supervisão, tive ainda a oportunidade de realizar estágio junto ao Programa de Aperfeiçoamento do Ensino - PAE, na disciplina Direito Econômico Internacional.

A realização deste trabalho se valeu ainda de frutíferos diálogos travados no Grupo Direito \& Políticas Públicas, coordenados pelo Prof. Dr. Diogo Rosenthal Coutinho e pela Prof. Dra. Ana Maria Nusdeo, a quem agradeço a orientação e auxílio na fase final de meu período como bolsista da FAPESP. Ao Prof. Titular Virgílio Afonso da Silva, a acolhida em seu Seminário de Pesquisa e a possibilidade de submeter as primeiras idéias deste trabalho ao crivo e sugestões de seus integrantes.

À minha família querida, dedico estas páginas, em retribuição ao carinho e ao amor de sempre. 


\section{CONSIDERACÕES PRELIMINARES}

A pesquisa sobre a regulação das microfinanças no Brasil revelou que a literatura jurídica nacional praticamente não se ocupa do tema, e com exceção de alguns estudos produzidos no âmbito da autoridade reguladora, o Banco Central do Brasil, não foram identificados trabalhos jurídicos atuais e significativos sobre o mesmo. A elaboração desta dissertação partiu, portanto, de uma primeira dificuldade, a impossibilidade de identificar e realizar a resenha de trabalhos jurídicos especializados que analisem o atual estado da legislação e regulamentação concernente à prestação de serviços microfinanceiros por meio de variada gama de agentes: sociedades de crédito ao microempreendedor, organizações não governamentais, organizações civis de interesse público, cooperativas de crédito, fundos públicos, programas governamentais e bancos privados.

Relatórios e estudos periodicamente elaborados pelo Banco Central do Brasil são a principal fonte de pesquisa na literatura jurídica nacional. Observe-se que, de certo modo, há um inconveniente que pode vir a ser significativo para o resultado da presente pesquisa: o acesso a estudos reveladores tão somente do ponto de vista da autoridade reguladora. Essa foi uma insuficiência detectada, e que de certa maneira tentou-se suprir por meio do relato de vozes dissonantes, identificadas em projetos de lei e em seminários sobre o tema.

Quanto à literatura internacional, os principais trabalhos com viés jurídico têm como foco a enunciação de princípios básicos a serem seguidos na regulação de instituições microfinanceiras, ou o quadro normativo necessário para a regulação e supervisão dessas instituições ${ }^{1}$.

Merecem destaque outras publicações de interesse para a presente pesquisa, como as do Comitê de Supervisão Bancária da Basiléia, que emite diretrizes uniformizadas internacionalmente tanto no que diz respeito à organização de instituições financeiras quanto à elaboração de contratos, investigação do perfil de renda de seus correntistas e avaliação de riscos, exigência e execução de garantias etc. Veja-se, por exemplo, o

\footnotetext{
${ }^{1}$ J. Ledgerwood \& V. White (org.), Transforming Microfinance Institutions - providing full financial
} services to the poor, Washington, The World Bank, 2006. 
documento "Os Princípios Essenciais da Basiléia - Princípios Essenciais para uma Supervisão Bancária Eficaz", elaborado pelo mesmo Comitê e divulgado pelo Banco Central do Brasil em seu sítio².

Apesar das restrições quanto à literatura existente, foram adotadas algumas fontes alternativas de pesquisa, como sítios de organizações internacionais, de instituições financeiras, do governo federal, e ainda a participação em seminários. Foi levada em conta, ainda, a opinião de agentes envolvidos na prestação de serviços microfinanceiros, da autoridade reguladora e de órgãos governamentais que direta ou indiretamente participam da formulação de políticas para o setor.

Como tentativa de tornar compreensível a vasta (e por vezes confusa) legislação em vigor e seus reflexos no cotidiano das instituições microfinanceiras, a presente dissertação foi dividida em 3 capítulos, seguidos das considerações finais que a encerram. Ao final de cada capítulo, procurou-se sintetizar alguns dos debates e dilemas captados em palestras, seminários e conversas com representantes de entidades e órgão regulador. No primeiro capítulo, são expostos alguns conceitos referentes ao arcabouço conceitual à disposição dos juristas para a compreensão das microfinanças como um setor específico inserto no Sistema Financeiro Nacional. Na seqüência, o Capítulo 2 analisa quais as formas jurídicas preferencialmente adotadas pelas instituições microfinanceiras e, eventualmente, quais as dificuldades que cada uma dessas formas apresenta na operacionalização e prestação de serviços microfinanceiros. Procura-se, ainda, correlacionar vantagens e desvantagens entre as formas sob exame, comparativamente. Os principais diplomas legais analisados são: Lei n. 9.790/99 (Organizações da Sociedade Civil de Interesse público), Lei n. 10.194/01 (Sociedades de Crédito ao Microempreendedor), Lei n. 4.595/64, 5.764/71 e 10.865/04 (que disciplinam o funcionamento das Cooperativas de Crédito), Lei 11.110/05 (Programa Nacional de Microcrédito Produtivo Orientado).

\footnotetext{
${ }^{2}$ Segundo o Banco Central do Brasil, "Este documento apresenta um conjunto abrangente de 25 Princípios Essenciais, que foram desenvolvidos pelo Comitê de Supervisão Bancária da Basiléia como referência básica para uma supervisão bancária eficaz. Os Princípios foram definidos para serem aplicados por todos os países, na supervisão dos bancos de suas jurisdições. Trata-se de uma tradução não oficial para o português, elaborada pelo Banco Central do Brasil, do documento originalmente intitulado 'Core Principles for Effective Banking Supervision', publicado pelo BIS - Banco de Compensações Internacionais, em setembro de 1997”. http://www.bcb.gov.br/ftp/defis/basileia.pdf (acesso em janeiro de 2008).
} 
Segue-se, no mesmo capítulo, a exposição de alguns dados sobre a prestação de serviços microfinanceiros no país. Atualmente, o principal programa de microcrédito em curso quanto a micro empréstimos concedidos que apresenta resultados satisfatórios no país é o Crediamigo, do Banco do Nordeste $-\mathrm{BNB}^{3}$. Segundo dados de abril de 2008, isoladamente, o Crediamigo seria responsável por $51,6 \%$ do financiamento ao microcrédito no país, seguido pelo Banco Nacional de Desenvolvimento Econômico e Social - BNDES $(14,7 \%)$, Banco Real $(13,8 \%)$, e outros agentes de menor vulto que somados representariam $19,9 \%{ }^{4}$.

Quanto aos números ora apresentados, não se pode negar que o crescimento do setor nos últimos anos tornou obsoletas muitas das pesquisas publicadas sobre o acesso a serviços financeiros no país. Pontos de partida sobre os quais o projeto inicial se baseou aparentam não serem mais reveladores da sua conjuntura, e a presente dissertação procura levar em conta tal transformação, ainda que as fontes de pesquisa atualizadas sejam escassas e exista pouca literatura jurídica sobre o tema. Tornou-se necessária a reformulação da premissa inicial, segundo a qual os entraves jurídicos existentes seriam tamanhos que impediriam o desenvolvimento do setor de microfinanças no Brasil.

Inicialmente, tomou-se como base trabalhos como os realizados pelo Banco Mundial, segundo as quais que as camadas mais pobres da população brasileira estariam impossibilitadas de acessar serviços financeiros em razão de uma regulamentação excessivamente restritiva e do desinteresse dos bancos comerciais em oferecê-los a esses potenciais consumidores ${ }^{5}$. Tais idéias foram temperadas em face do impacto bem-sucedido de programas como o Crediamigo, do BNB, do interesse de bancos comerciais no setor microfinanceiro (como Unibanco, Real, Itaú, Santander Banespa e Bradesco), e das iniciativas locais de organização de instituições microfinanceiras para o atendimento de algumas comunidades.

Além de seu oferecimento pela variada gama de agentes já destacados no início desta Introdução, haveria ainda uma segunda possibilidade de acesso a serviços de crédito

\footnotetext{
${ }^{3}$ O Crediamigo foi estudado a fundo no trabalho elaborado sob a coordenação do pesquisador Marcelo Côrtes Néri, "Microcrédito, o Mistério Nordestino e o Grammen Brasileiro", Rio de Janeiro: FGV/IBRE, CPS, 2008.

${ }^{4}$ Os números foram apresentados por Stélio Gama Lyra Jr. no VII Seminário BACEN Microfinanças.

${ }^{5}$ A. Kumar . Access to financial services in Brazil-Directions in Development, cit.
} 
e financiamento que não fora aventada no início da pesquisa: os bancos comerciais prestariam serviços de forma indireta à população, na medida em que se relacionam com casas de crediário e grandes varejistas que financiam produtos diretamente ao consumidor de baixa renda, ainda que praticando taxas de juros significativamente altas. $\mathrm{O}$ acesso às franjas do sistema financeiro formal ocorreria pela via do financiamento de bens de consumo por varejistas.

Dentre os agentes prestadores de serviços microfinanceiros, a presente dissertação dispensará especial atenção à atuação de uma instituição financeira pública, o BNB, que além de banco múltiplo acumula a função de agente da Superintendência de Desenvolvimento do Nordeste - SUDENE, órgão vinculado ao Ministério da Integração Social. Seu papel no atual panorama das microfinanças no país foi percebido no decorrer da pesquisa como indicativo da importância da participação do poder público não só na formulação de diretrizes para a prestação de serviços microfinanceiros e dos correlatos objetivos a serem perseguidos, mas também na sua concretização. Como destacado no Capítulo 2, o Crediamigo criou modelos seguidos não só por outros programas públicos, mas também pelo setor privado.

Deve ser considerada ainda a atuação do Banco Nacional de Desenvolvimento Social (BNDES), por meio de pesquisas e, especialmente, pela disponibilização de recursos desde o início dos anos 2000. Atualmente, contribui para o aprimoramento do setor por meio de programas para o financiamento e capacitação de instituições microfinanceiras articuladas a políticas públicas de cunho social (v. Capítulo 3).

No campo das políticas governamentais, observa-se ainda a crescente utilização do microcrédito em políticas públicas capitaneadas pelo Ministério do Trabalho e Emprego, no âmbito do Programa Nacional de Microcrédito Produtivo Orientado (PNMPO), e pelo Ministério do Desenvolvimento Social, sob a forma de apoio a microempreendedores beneficiários do Bolsa Família (v. Capítulo 3). Com a mesma finalidade de utilizar as microfinanças como forma de superação da pobreza, a Secretaria de Economia Solidária planeja criar, em 2009, nove Bancos Comunitários inspirados na experiência do Banco Palmas, criado em Recife por iniciativa de uma associação de bairro ${ }^{6}$ (v. Capítulo 2 ).

\footnotetext{
${ }^{6}$ Banco comunitário pode ser definido, a princípio, como um "conjunto de serviços financeiros de caráter solidário, em rede, de natureza associativa e comunitária, voltado para o desenvolvimento e reorganização da
} 
No decorrer da pesquisa e da elaboração desta dissertação, tornou-se mais nítida a nuance de política pública que paulatinamente as microfinanças adquirem no país. Não parece proceder o argumento de sua circunscrição à estrita esfera das relações privadas, baseado no crescente interesse dos bancos comerciais na prestação de serviços microfinanceiros e na sua capacidade de, em tese, prover tais serviços de modo satisfatório e a custos significativamente mais baixos em decorrência da sua massificação (benefícios de escala). Apesar da crescente comercialização de serviços e produtos microfinanceiros pelos bancos privados, não se pode negar a existência paralela e significativa de iniciativas que reafirmam o tratamento do tema no âmbito de uma política social de natureza inclusiva. De fato, percebia-se nos trabalhos do início dos anos 2000 uma cisão entre duas opiniões: uma primeira, segundo a qual a prestação de serviços estaria bem a cargo dos bancos comerciais, e uma outra, partidária da sua regulamentação em um microssistema apartado, mas que guardaria alguns pontos de contato com o sistema financeiro organizado pela Lei 4.595/64 e submetido à regulação do Banco Central. Hoje essa cisão parece perder sentido, pois serviços microfinanceiros são prestados no país sob diversas formas jurídicas, com ou sem intuito lucrativo, pela iniciativa privada ou pelo poder público em programas sociais de natureza inclusiva, levados a cabo por diferentes entes integrantes da Administração Pública direta e indireta. Com segurança, pode-se apenas afirmar que situar a prestação de serviços microfinanceiros como tarefa exclusiva da iniciativa privada ou do poder público não encontra amparo no panorama atual das microfinanças no Brasil.

Quanto às características do modelo institucional que permitiriam ao poder público regular e fiscalizar a prestação desses serviços, a observação do diálogo entre autoridade monetária e formuladores de políticas sociais revelou que, apesar da atuação regulatória e incisiva de um específico órgão sobre o setor, o Banco Central do Brasil, tornou-se essencial à dinâmica da formulação e condução de políticas públicas para as microfinanças no país a ação concertada de diferentes entes da Administração Pública. Estes entes, apesar de não imbuídos da específica competência que lhes permitiria regrar pormenorizadamente a postura dos agentes envolvidos na prestação de serviços microfinanceiros, parecem participar ativamente, em diferentes graus e de acordo com sua função e com os

economia local, tendo por base os princípios da economia solidária" (conceito dado por Antônio Haroldo Pinheiro Mendonça, da Secretaria de Economia Solidária do Ministério do Trabalho e Emprego e Emprego, em palestra proferida no VII Seminário BACEN Microfinanças). 
respectivos fins buscados, na elaboração de diretrizes e programas que tornam efetivas e úteis à população de baixa renda facilidades como o microcrédito, microsseguro, conta e poupança simplificadas etc. Essencialmente, este trabalho conclui que a utilização das microfinanças como uma das possíveis formas de aliviar a pobreza e oferecer perspectivas promissoras de geração de renda seria inócua se estivesse apenas nas mãos de uma autoridade monetária e reguladora "cega" às especificidades que marcam o modo de vida de nossa população de baixa renda. Do mesmo modo, seria provável o fracasso da tão somente bem-intencionada formulação de políticas sociais indiferentes ao plexo de normas que estruturam o Sistema Financeiro Nacional. As considerações finais desta dissertação buscam respaldo em estudos que privilegiam os processos críticos que, a muitas mãos, estabelecem o traçado de políticas públicas, em detrimento daqueles que, unilateralmente, tão somente focam sua substância e orientação. Na tecelagem da complexa trama das microfinanças no Brasil, em que se entrecruzam mercado e políticas sociais, poder público, iniciativa privada e sociedade civil, revelou-se evidente a importância do diálogo institucional para discussões, negociações, aprovação e execução de políticas. Seria essa a premissa para uma regulação consciente e para políticas sociais virtuosas. E não poderia deixar de ser, enfim, a nota que sugestiona o presente olhar sobre o tema. 


\title{
CAPÍTULO 1 \\ AS MICROFINANÇAS: SEUS CONCEITOS, PANORAMA \\ INSTITUCIONAL E ARCABOUÇO NORMATIVO
}

\begin{abstract}
O PRESENTE CAPÍTULO, FUNDAMENTALMENTE, EXPÕE CONCEITOS PERTINENTES AO CAMPO DO SISTEMA FINANCEIRO QUE TRATA DAS FERRAMENTAS REGULATÓRIAS PARA A PRESTAÇÃO DE SERVIÇOS ÀQUELES QUE DISPÕE DE POUCO VOLUME DE RECURSOS PARA MOVIMENTAR EM CONTA CORRENTE, APLICAR EM CONTA POUPANÇA, CONTRATAR SEGUROS E EMPRÉSTIMOS ETC. A CONJUGAÇÃO DO PREFIXO GREGO MICRO À PALAVRA FINANÇAS DEU ORIGEM AO TERMO QUE HOJE DENOMINA ESSE ESPECÍFICO SETOR.
\end{abstract}

\subsection{Introdução}

Como poderia parecer à primeira vista, o prefixo micro não diz respeito apenas ao pequeno montante de recursos para sustentar necessidades pessoais ou impulsionar uma atividade microempreendedora. Há uma peculiar tecnologia e um arcabouço normativo próprio que envolvem a prestação de serviços financeiros para a população de baixa renda, sem condições econômicas para acessar os produtos convencionalmente ofertados pelas instituições bancárias comerciais ou pendurada a estas por "franjas", permissivas de alguma relação de consumo, frequentemente contratada mediante o pagamento de juros extorsivos e ocultos sob o endividamento a longo prazo.

Para os limites da presente dissertação, baixa renda tangencia o significado de pobreza, como impossibilidade de acessar, de forma segura e contínua, os bens e serviços necessários à sobrevivência digna. Inerente, portanto, a tal noção, a instabilidade da atividade produtiva e da sua renda, geradora de incertezas quanto à manutenção da própria saúde, ao desenvolvimento e à educação dos filhos, à segurança na velhice.

Conceitos colhidos em estudos produzidos no âmbito do Banco Central do Brasil ${ }^{7}$ apresentam as microfinanças como a "prestação de serviços financeiros adequados e

\footnotetext{
${ }^{7}$ Faz-se referência à publicação mais recente em que tais conceitos são expostos: Microfinanças: O papel do Banco Central do Brasil e a importância do cooperativismo de crédito, $2^{\mathrm{a}}$ edição, revista e ampliada,
} 
sustentáveis para a população de baixa renda, tradicionalmente excluída do sistema financeiro tradicional, com utilização de produtos, processos e gestão diferenciados" ${ }^{\prime 8}$.

Seus princípios-chave e metodologia foram definidos em 2004 pelo Grupo Consultivo para a Assistência aos Pobres (GCAP, do qual participam o Banco Mundial, a Organização das Nações Unidas e mais 26 agências de desenvolvimento públicas e privadas $)^{9}$, e seguem enumerados:

1. Os pobres não necessitam apenas de empréstimos, mas sim de uma variedade de serviços financeiros;

2. As microfinanças são um instrumento poderoso na luta contra a pobreza;

3. As microfinanças significam a construção de sistemas financeiros que sirvam aos pobres;

4. As microfinanças podem e devem ser auto-suficientes, para atingir um grande número de pessoas pobres;

5. As microfinanças tratam da construção de instituições financeiras de atuação local em caráter permanente;

6. O microcrédito não é resposta para tudo nem o melhor instrumento para todos, em todas as circunstâncias;

7. O estabelecimento de tetos às taxas de juros afeta negativamente os pobres e torna o acesso ao crédito mais difícil;

8. O governo deve atuar de modo a viabilizar a realização de serviços financeiros, e não os fornecer diretamente;

9. Os fundos dos doadores devem complementar o capital privado, e não competir com ele;

10. O maior gargalo na indústria das microfinanças é a ausência de instituições e executivos fortes; e

11. As microfinanças funcionam melhor quando têm o seu desempenho medido e publicado.

Brasília, BCB, 2008, da autoria de Marden Marques Soares e Abelardo Duarte de Melo Sobrinho, pp. 23 e 24.

${ }^{8} \mathrm{O}$ conceito é o mesmo utilizado pelo Serviço Brasileiro de Apoio às Micro e Pequenas Empresas (Sebrae) em seu sítio, www.sebrae.com.br.

9 www.cgap.org 
Apesar de não poder ser considerado panacéia, o instrumento mais em voga no campo das microfinanças hoje é o microcrédito, incorporado a políticas públicas promovidas pelo governo federal, bem como objeto de propostas legislativas inovadoras transformadas em lei e de minuciosa regulamentação pelos órgãos reguladores do Sistema Financeiro Nacional. O microcrédito abarca a gama dos serviços microfinanceiros direcionados especificamente à atividade produtiva. De acordo com estudos do Banco Central do Brasil, são oferecidos "exclusivamente a pessoas físicas e jurídicas empreendedoras de pequeno porte, diferenciando-se dos demais tipos de atividade microfinanceira também pela metodologia utilizada, bastante diferente daquela adotada para as operações de crédito tradicionais ${ }^{10}$. É entendida como principal atividade do setor de microfinanças pela importância para as políticas públicas de superação da pobreza e também pela geração de trabalho e renda". No plano legal, destaca-se mais recentemente a a Lei n. 11.110/05, que denominou Microcrédito Produtivo Orientado (MPO) a concessão de crédito "baseada no relacionamento direto com os empreendedores no local onde é executada a atividade econômica"11.

O estímulo ao microempreendedorismo é uma resposta possível ao grande contingente de trabalhadores alijados do mercado de trabalho formal, detentores de plena capacidade e aptidão para o desempenho de atividades produtivas. Dada a condição de incerteza e insegurança econômica experimentada por essa população, por vezes o acesso às facilidades que o sistema financeiro pode oferecer, como o financiamento bancário, acaba por se demonstrar inviável em razão de fatores como a exigência de determinadas garantias e contrapartidas para a sua concessão.

As primeiras experiências em microcrédito surgiram há algumas décadas, no contexto da atuação de organizações não-governamentais de diversos países, e mais recentemente vêm sendo adotada como estratégia de governamental para a redução da pobreza e para a geração de renda. Seu objetivo primordial, portanto, é suprir a carência de crédito produtivo para os micro e pequenos empreendedores, bem como facilitar seu acesso a outros serviços microfinanceiros.

\footnotetext{
${ }^{10}$ Essa tecnologia pode ser resumida à utilização de (i) agente de crédito; (ii) garantia solidária; e (iii) prazos curtos e valores crescentes.

${ }^{11}$ Por ser pertinente ao tema da utilização das microfinanças em programas governamentais e políticas públicas, a metodologia empregada pela Lei n. 11.110/05 será objeto de análise no Capítulo 3 .
} 
Em face dos conceitos supra, estão excluídas no que ora se denomina microcrédito variações de crédito popular oferecidas por financiadoras, bancos ou casas de varejo. Ainda que similares quanto à faixa de renda de seu público e aos reduzidos montantes, possuem metodologia e finalidades diversas, que podem ser resumidas no quadro a seguir:

\begin{tabular}{|c|c|}
\hline Crédito Popular & Microcrédito \\
\hline $\begin{array}{l}\text { Repercussões sociais e efeito multiplicador } \\
\text { de renda são irrelevantes; }\end{array}$ & $\begin{array}{l}\text { Crédito utilizado como ferramenta de } \\
\text { políticas sociais; }\end{array}$ \\
\hline $\begin{array}{l}\text { tem como requisitos para concessão } \\
\text { documentação formal extensa, garantias } \\
\text { reais, informações contábeis, cadastros } \\
\text { restritivos (SPC, SERASA); }\end{array}$ & $\begin{array}{l}\text { tem como requisitos para concessão } \\
\text { documentação formal reduzida, garantias } \\
\text { como aval solidário, características do } \\
\text { empreendedor e de sua atividade; }\end{array}$ \\
\hline $\begin{array}{l}\text { operações individuais e que não guardam } \\
\text { relação com concessões futuras, } \\
\text { atendimento impessoal e burocrático, prazos } \\
\text { de vencimento longos, maximização do } \\
\text { lucro por parte do banco; }\end{array}$ & $\begin{array}{l}\text { empréstimos a grupos de empreendedores } \\
\text { solidários, relação de continuidade, elo } \\
\text { entre a instituição - agentes de crédito e } \\
\text { tomadores, prazos de vencimento curtos, } \\
\text { sem fim lucrativo; }\end{array}$ \\
\hline $\begin{array}{l}\text { não há finalidade pré-determinada, } \\
\text { freqüentemente utilizado para consumo e } \\
\text { pagamento de dívidas. }\end{array}$ & $\begin{array}{l}\text { há metodologia específica para direcionar a } \\
\text { utilização dos recursos a fins produtivos, de } \\
\text { modo sustentável. }\end{array}$ \\
\hline
\end{tabular}

Cumpre salientar que literatura internacional identifica duas principais correntes quanto aos objetivos do microcrédito: uma primeira que defende seu viés desenvolvimentista, segundo a qual o microcrédito seria uma forma de combater os problemas estruturais que levam à pobreza e, as instituições microfinanceiras, agentes de desenvolvimento social. Nesse sentido, a concessão do crédito deve estar acompanhada, por exemplo, da educação financeira e da capacitação técnica do trabalhador, do acompanhamento da evolução de seu empreendimento, de modo a privilegiar o seu caráter de política pública de cunho social. Já uma segunda corrente, minimalista, entende que o microcrédito deve ser concedido de forma impessoal e segundo as regras de mercado, considerando que o esforço das instituições deve se concentrar na recuperação de seus investimentos e na geração dos recursos garantidores da sua auto-sustentabilidade, tendo como objetivos apenas oferecer serviços com alto nível de eficiência e qualidade sem 
vinculá-los à capacitação prévia dos tomadores. ${ }^{12}$ Há, ainda, terceira corrente que busca conciliar os objetivos de cunho social aos econômicos, i. e, a manutenção dos lucros garantidores da auto-sustentabilidade da instituição e a prestação de serviços microfinanceiros às camadas mais carentes da população ${ }^{13}$.

Atualmente, no quadro normativo brasileiro dos agentes prestadores de serviços microfinanceiros, podem ser identificadas formas jurídicas inspiradas tanto na corrente desenvolvimentista, como é o caso das Organizações Civis de Interesse Público, quanto na corrente minimalista, como é o caso das Sociedades de Crédito ao Microempreendedor. Essas formas e seus objetivos são detalhadas a seguir, no Capítulo 2.

Para os fins a que se propõe a presente dissertação, as duas principais correntes possuem seu valor, e encontrar o melhor meio de conjugá-las parece ser a resposta ideal. Inegavelmente, considera-se o papel desenvolvimentista dessas instituições sua principal função e razão de ser. Do contrário, não faria sentido sua existência em paralelo ou mesmo de forma articulada a entidades reguladas no âmbito do Sistema Financeiro Nacional. Por outro lado, a auto-sustentabilidade pode e deve ser perseguida, pois não se cogita que as microfinanças constituam novo capítulo da Assistência Social de um país. Se um dos seus principais objetivos é a emancipação da população pobre e com poucas perspectivas de alcançar uma vida laboral estável, mas com potencial de prover o próprio sustento a partir de condições que as alcancem nas suas especificidades, a devolução às instituições dos recursos que lhes são emprestados constitui a prova de que é possível sim alçá-las de tal situação de descrença.

Imersa nessas preocupações, a presente dissertação tem por objetivo tratar das técnicas microfinanceiras que interessam às finalidades de redução da pobreza e geração de trabalho e de renda, sejam elas utilizadas por instituições financeiras ou não (bancos públicos ou privados, Sociedades de Crédito ao Microempreendedor, Organizações Civis de Interesse Público, programas governamentais). Impõem-se algumas tarefas à realização da análise proposta, sendo a primeira distinguir o público-alvo das microfinanças e do microcrédito (item 1.2, infra). Na seqüência, (item 1.3) serão estudadas algumas

\footnotetext{
12 J. Ledgerwood, Microfinance Handbook: an institutional and financial perspective, Washington D.C., World Bank, 1998.

${ }^{13}$ M. Otero, R. Rock, S. Saltzman, Principles and practices of microfinance governance, Washington D.C., Acción International, 1998.
} 
características do modelo legal e institucional que permite a regulação e supervisão das microfinanças no Brasil. No próximo capítulo, será objeto de breve exposição quais as formas jurídicas à disposição dos entes públicos e privados que hoje, no Brasil, oferecem à população de baixa renda serviços microfinanceiros ${ }^{14}$.

1.2 Microfinanças para quem? O público-alvo.

Nos termos das definições supra, o público-alvo das instituições prestadoras de serviços microfinanceiros seria a população pobre ou de baixa renda. Dentro desta categoria, famílias, pequenos empreendedores, beneficiários da Seguridade Social (Previdência e Assistência Social). Sob outro enfoque, haveria alguma diferenciação a ser feita no que diz respeito às finalidades perseguidas pelas instituições microfinanceiras individualmente consideradas. A depender dos fins buscados pela instituição, por regra, há especialização no atendimento a pessoas em situações econômicas ou laborais similares. $\mathrm{O}$ tema será tratado com mais detalhes no Capítulo 2, infra, oportunidade serão analisadas as diferentes formas jurídicas que hoje viabilizam a prestação de serviços microfinanceiros no país.

O microcrédito, por regra, acaba por atender predominantemente microempreendedores do sistema dito 'informal' da economia. A informalidade, de acordo com uma certa visão, "reflete a incapacidade do Estado de abrigar o conjunto das atividades e relações econômicas e sociais da população" ${ }^{" 15}$. Delimitar qual fatia da população pertence a esse grupo mereceria por si só uma pesquisa vasta e aprofundada, em vista das dimensões territoriais e populacionais do nosso país, bem como das diversas subclassificações de níveis de renda possíveis ${ }^{16}$.

14 O Capítulo 2 tratará com maior vagar informações quanto à demanda por serviços microfinanceiros, participação de agentes prestadores e atual peso de programas públicos no país.

${ }^{15}$ S. Parente, Microfinanças - saiba o que é um banco do povo, Brasília, Agência de Educação para o Desenvolvimento, 2002, p. 131.

${ }^{16}$ Apesar do crescimento das políticas públicas para o atendimento das necessidades dessa população, a proporção de pobres na população total pode ser considerada alta: em 2004, representava 33,21\% (ou 57,7 milhões de pessoas), e seu subconjunto indigentes perfazia $8 \%$ da população do país (ou 13,9 milhões de pessoas). Os números não incluem a Região Norte rural (exceto Tocantins rural). O estudo foi realizado pela economista Sônia Rocha a partir dos resultados da Pesquisa Nacional por Amostras de Domicílio realizada em 2004 pelo IBGE. Apesar dos números apontarem queda da pobreza no país, em detalhe indicam o agravamento da pobreza em algumas áreas, como a região metropolitana de São Paulo, e a manutenção da desigualdade entre áreas, como é o caso da continuidade da participação relativa da pobreza na região Nordeste. ROCHA, S. “Alguns aspectos relativos à evolução 2003-2004 da pobreza e da indigência no Brasil", janeiro de 2006. 
Há uma questão, ainda não plenamente equacionada no plano jurídico, que merece reflexão por dizer respeito ao pano de fundo do presente estudo: como o direito e nosso sistema normativo têm desenvolvido ferramentas para lidar com esse novo universo de relações travadas no âmbito da economia informal. Acostumados à dicotomia do público vs. privado, aos juristas é apresentado o desafio de incorporar ao seu discurso e às suas técnicas novos conceitos que dêem conta de relações híbridas, apoiadas em políticas públicas de cunho social, mas que florescem no campo das chamadas relações privadas ou patrimoniais e que, por vezes, escapam às estruturas normativas acentuadamente tradicionais e legalistas. Ao buscar compreender a tarefa a ser desempenhada pelo poder público nesse novo campo de relações, o direito não pode confundi-la com a mera manutenção de um sistema de proteção social que garanta o mínimo existencial aos alijados do mercado de trabalho formal. Haveria um nível intermediário a desafiar a técnica jurídica: o 'informal' (tido, muitas vezes, por ilegal), apresenta dilemas que não podem ser ignorados pelo poder público ou pretensa e falsamente resolvidos na esfera punitiva $^{17}$.

Fato é que, formais ou informais, as microempresas podem ser pontuadas na legislação brasileira como "a menor unidade econômica independente" e conceituadas como "unidades muito pequenas geradoras de renda familiar, cujos proprietários trabalham diretamente no dia-a-dia dos empreendimentos, acumulando funções produtivas e gerenciais, com pequeno número de pessoas ocupadas, recorrendo principalmente aos membros da família, dispondo de pouco capital e tecnologia rudimentar"18. A pesquisa “Economia Informal Urbana de 2003” (Ecinf 2003), realizada no âmbito de parceria entre o Instituto Brasileiro de Geografia e Estatística (IBGE) e o Serviços Brasileiro de Apoio às Micro e Pequenas Empresas (SEBRAE) constatou que, no universo de 10.525.954 pequenas empresas não agrícolas compostas por até cinco pessoas, 10.335 .962 seriam responsáveis por empregar 13.860.868 trabalhadores diretos, e poderiam ser classificadas como informais.

\footnotetext{
${ }^{17}$ V. no item 2.2, b.1, infra, o relato da experiência de um 'banco' criado às margens do sistema financeiro (isto é, de modo a aparentemente desafiar suas normas) por uma associação de moradores da periferia do Recife, e que hoje representa modelo para a criação de novos bancos comunitários pela Secretaria Nacional de Economia Solidária.

${ }^{18}$ Conceito de Valdi de Araújo Dantas citado por Silvana Parente na obra Microfinanças - saiba o que é um banco do povo, Brasília, Agência de Educação para o Desenvolvimento, 2002, p. 23.
} 
Ainda que não exista um conceito jurídico perfeito e acabado do que seja a informalidade, pode se inferir que dela derive a inobservância de regras atinentes à constituição e manutenção regular de uma empresa. Veja-se, como forma de ilustrar tal situação, quadro concebido pelo Centro de Políticas Sociais da Fundação Getúlio Vargas, a partir de dados obtidos pela pesquisa Ecinf 2003, quanto a porcentagens de empresas brasileiras que cumprem a legislação e regulamentos pertinentes à sua regularização perante os poderes públicos:

\begin{tabular}{cccccccc}
\hline & $\begin{array}{c}\text { Constituição } \\
\text { jurídica }\end{array}$ & CNPJ & $\begin{array}{c}\text { Registro } \\
\text { de micro }\end{array}$ & $\begin{array}{c}\text { Declaração } \\
\text { de IR }\end{array}$ & SIMPLES & Licenças & $\begin{array}{c}\text { Filiação } \\
\text { ente } \\
\text { classe }\end{array}$ \\
\hline Brasil & 11,61 & 11,27 & 9,72 & 8,76 & 2,14 & 22.65 & 10,67 \\
\hline $\begin{array}{c}\text { Com } \\
\text { acesso a } \\
\text { crédito }\end{array}$ & 29,25 & 28,82 & 24,88 & 22,74 & 4,64 & 42,70 & 18,94 \\
\hline $\begin{array}{c}\text { Sem } \\
\text { acesso a } \\
\text { crédito }\end{array}$ & 10,47 & 10,13 & 8,74 & 7,85 & 1,98 & 21,35 & 10,13 \\
\hline Fonte: $\mathrm{CPS} / \mathrm{IBRE} / \mathrm{FGV}$ & & & & & & \\
\hline
\end{tabular}

Constatou-se ainda que $94 \%$ dessas empresas não tivera acesso a crédito nos três meses anteriores à pesquisa. Quanto aos demais serviços financeiros, foi verificado que apenas $40 \%$ desses empregadores possuíam conta corrente, sendo que 32\% tinham acesso a talões de cheque, $37 \%$ efetuavam pagamentos via correspondentes bancários ${ }^{19}$, e $34 \%$ utilizavam agências bancárias.

No que diz respeito à demanda por microcrédito, a Ecofin 2003 chegou ao número de dezesseis milhões de unidades produtivas, sendo que treze milhões seriam compostas por trabalhadores por conta própria, dos quais sete milhões seriam potenciais clientes, i. e, exerceriam demanda efetiva por microcrédito. Em valores totais, tal demanda poderia ser traduzida em doze bilhões de reais, o que representaria menos de 1\% do PIB brasileiro.

Quanto aos dados sobre a oferta de serviços microfinanceiros, as estatísticas do BCB dão claramente conta da sua evolução: em 2005, 2,3\% da demanda era atendida; em 2006, $10 \%$ e, finalmente em dezembro de 2007, existiam cerca de 228 instituições microfinanceiras que atendiam por volta de um milhão de clientes ativos, i. e, 16\% da

\footnotetext{
${ }^{19}$ Sobre a caracterização dos correspondentes bancários, v. Capítulo 2, item 2.2, a.1, infra.
} 
demanda $^{20}$. Números detalhados sobre a composição da oferta de microcrédito no país serão expostos no Capítulo 2.

Observa-se, de toda sorte, uma estreita ligação do microcrédito com o potencial de trabalho de seu público, desprovido dos requisitos para acessar o concorrido e cada vez mais estreito mercado de trabalho formal. Este ponto revela uma dificuldade a ser equacionada para que as ferramentas microfinanceiras sejam bem empregadas: conjugar, à boa técnica financeira, a consciência das peculiaridades de uma população que situa a quase totalidade de suas relações no plano da informalidade. Esta é a característica fundamental que faz do microcrédito uma ferramenta muito peculiar dentro do quadro das políticas públicas de cunho social: não se trata apenas de uma nova forma de transferir renda aos mais pobres, ou, no âmbito do Sistema Financeiro Nacional, uma técnica de simplificação de formalidades atinentes à celebração de contratos. O microcrédito, ainda, não tem por objetivo disponibilizar numerário para a aquisição dos bens de consumo ditos supérfluos. Esta se revela preocupação secundária, adstrita aos insumos necessários para a subsistência da atividade produtiva desempenhada. Dito ainda de outra maneira, as facilidades disponibilizadas ao público não possuem um fim concreta e imediatamente dimensionado nas pequenas somas que são transacionadas ou mesmo no quanto são capazes de adquirir de imediato, mas sim no processo de emancipação e bem-estar experimentado pelas famílias envolvidas no curso de seu uso reiterado e sustentável.

\subsection{Microfinanças por quem? O panorama institucional.}

É corrente na literatura internacional ${ }^{21}$ o entendimento de que a estrutura institucional do setor microfinanceiro deve contar com três níveis de atuação complementar:

i) o nível macro, ou seja o ambiente econômico e político facilitador e estável, propício à manutenção de políticas financeiras favoráveis à população de baixa

\footnotetext{
${ }^{20}$ M. M. Soares \& A. D. Melo Sobrinho, Microfinanças - O papel do Banco Central do Brasil e o cooperativismo de crédito, $2^{\mathrm{a}}$ edição, revista e ampliada, Brasília: Banco Central do Brasil, 2008, pp. 29-30.

${ }^{21}$ V. por todos, R. P. Christen, T. R. Lyman, R. Rosenberg, Microfinance consensus guidelines - guiding principles on regulation and supervision on microfinance, Washington, Consultative Group to Assist the Poor/The World Bank Group, 2003.
} 
renda, em que seriam fundamentais o papel da legislação, da regulação e da supervisão;

ii) o nível meso, representado pela infra-estrutura geral de apoio do sistema financeiro (sistemas de transferências e pagamentos, armazenamento de dados e tecnologia da informação etc); e

iii) o nível micro, representado por provedores de varejo de diferentes tipos (companhias organizadas por ações, organizações mútuas ou cooperativas, organizações não-governamentais ou organizações da sociedade civil, e até mesmo indivíduos), sendo que tal diversificação de prestadores é vista por alguns como nota característica de um sistema financeiro inclusivo ${ }^{22}{ }_{-} 23$.

No Brasil, pode-se sem maiores dificuldades identificar como principais atores no nível macro o Conselho Monetário Nacional e o Banco Central do Brasil, sendo o último responsável pela fiscalização das atividades das instituições financeiras do país. A mesma facilidade não existe quanto às instituições atuantes no nível micro, organizadas sob as mais diversas formas jurídicas. Há, na literatura nacional, a tendência a traçar a seguinte tipologia: i) instituições da sociedade civil (organizações não-governamentais e organizações da sociedade civil de interesse público); ii) programas de governos locais (estaduais e municipais); iii) cooperativas de crédito; iv) sociedades de crédito ao microempreendedor; e v) programas de bancos comerciais ${ }^{24}$.

Ao recorte feito pelo presente estudo importa essencialmente a complementaridade entre os níveis macro e micro da estrutura institucional do sistema microfinanceiro. O nível macro (em especial o órgão regulador), por sua vez, se relacionaria com a variada gama de agentes ( $i$ a $v$, supra), que preliminarmente podem ser contrapostas em dois grandes grupos: um primeiro que de alguma forma estabelece relações diretas com as políticas

\footnotetext{
${ }^{22}$ Questões de regulação e supervisão do microsseguro, p. 16, documento elaborado pelo Grupo de Trabalho Conjunto IAIS-CGAP sobre Microsseguro aprovado na Basiléia em maio de 2007 (as siglas identificam respectivamente a International Association of Insurance Supervisors e o Consultative Group to Assist the Poor, ligado ao Banco Mundial)

${ }^{23}$ Pela expressão 'sistema financeiro inclusivo' o Grupo Consultivo para a Assistência aos Pobres entende "a integração de microfinanças no sistema financeiro formal para assegurar permanente acesso a serviços financeiros para um número significativo de pessoas pobres".

24 C. E. F. Carvalho \& C. T. Ribeiro, Do microcrédito às microfinanças: desempenho financeiro, dependência de subsídios e fontes de financiamento, São Paulo, Fapesp, EDUC, 2006, p. 150.
} 
sociais formuladas pelo Estado ( $i$ a iii), e um segundo que atuaria no setor predominantemente com intuito lucrativo $(i v \text { e } v)^{25}$. No que concerne à complementaridade entre órgão regulador e agentes, o presente estudo observou que, para cada um dos dois grupos, há um específico modo pelo qual são criadas as condições para a sua atuação.

Do ponto de vista das instituições que atuam direta ou subsidiariamente às políticas sociais formuladas pelo Estado, a criação da estrutura normativa propícia à sua existência e funcionamento depende em grande parte da afinidade entre o agente regulador e os formuladores das políticas. Nesse sentido, percebe-se como fator determinante da qualidade de seus resultados a capacidade desses atores em cooperar ao longo do processo de maturação da regulamentação de fundo e da elaboração das políticas que põem em prática os instrumentos normativos. A conclusão deriva da observação dos trabalhos desenvolvidos pelo Conselho da Comunidade Solidária por ocasião da concepção do marco regulatório no final dos anos 90, do Grupo de Trabalho Interministerial de Microcrédito e Microfinanças, e mais recentemente diálogos travados entre o Banco Central, o Ministério do Trabalho e Emprego e a Secretaria Nacional de Economia Solidária para a concepção de instrumentos normativos adequados ao Sistema Financeiro Nacional, e seus reflexos decisivos em políticas públicas de redução de pobreza e geração de renda, tema analisado no Capítulo 3 desta dissertação.

Por outro lado, quanto aos agentes econômicos que atuam nesse segmento com objetivo de exploração de atividade lucrativa, o enfoque é diverso. Indaga-se, quanto a esses agentes, qual seria o tipo de regulação adequada ao estímulo à sua maior participação no setor: se do tipo "comando-e-controle" ou se baseada em estímulos, levando-se em conta principalmente os efeitos distributivos das duas estratégias ${ }^{26}$. Supõe-se que a imposição direta, pelo Estado, da obrigatoriedade de determinada conduta pelo agente econômico geraria limitados efeitos ao desenvolvimento do setor, pois sua atuação seria restrita ao cumprimento da obrigação imposta, enquanto que a regulação por estímulos cultivaria o crescimento da prestação de serviços microfinanceiros pelos bancos comerciais em medida superior ao mínimo imposto. Algumas medidas governamentais destinadas ao

\footnotetext{
${ }^{25}$ Ainda assim, não é de todo incomum que as duas últimas formas atuem no segmento sob finalidades que extrapolem a mera exploração de uma atividade lucrativa, como é o caso das sociedades de crédito ao microempreendedor controladas por organizações civis de interesse público e das carteiras de microcrédito de bancos públicos, conforme relatado infra (item 1.3).

${ }^{26}$ A. Ogus, "Corrective Taxes and Financial Impositions as Regulatory Instruments", in The Modern Law Review, v. 61, November, n. 6, 1998.
} 
setor são analisadas neste capítulo nos itens subseqüentes, enquanto o Capítulo 2 apresentará dados recentes sobre a prestação de serviços microfinanceiros no país.

A seguir, serão estudados separadamente o nível macro e micro da estrutura institucional do setor microfinanceiro. O próximo tópico realiza uma breve exposição do histórico das microfinanças no país, com objetivo de ilustrar o contexto de concepção da legislação, da regulação e dos instrumentos de supervisão que constituem o arcabouço necessário à manutenção da prestação de serviços financeiros à população de baixa renda no Brasil. Inicia o capítulo seguinte a análise das formas jurídicas hoje à disposição dos agentes, públicos e privados, atuantes no setor. Procura-se, ainda, considerar sob enfoques distintos as peculiaridades dos prestadores de serviços que predominantemente perseguem lucro e aquelas pertinentes às instituições que de algum modo se relacionam com as políticas públicas de redução de pobreza e geração de renda.

a) Antecedentes do marco regulatório das microfinanças

Historicamente, a utilização das microfinanças como forma de impulsionar as atividades de produtores agrícolas e salvaguardar trabalhadores industriais (cooperativas e ligas de crédito) remonta ao século XIX, e perpassa crises financeiras e industriais da segunda metade do século XX, e a literatura nacional e internacional repisa à exaustão tais experiências, que podem ser vistas, para fins deste estudo, como seu passado remoto. $\mathrm{O}$ modelo e metodologia mais difundidos atualmente, tal como apontado pelas agências de desenvolvimento em todo o mundo é, sem dúvida, o concebido em Bangladesh por Muhammad Yunus em 1976, o Grameen Bank, ou Banco da Aldeia ${ }^{27}$.

O Brasil, em relação à África, Ásia e mesmo América Latina, tardiamente passou a adotar de forma massificada as microfinanças, e especificamente o microcrédito, como instrumento de redução de pobreza. São comumente apontadas como razões para tanto "as altas taxas inflacionárias, a tradição do crédito governamental dirigido e subsidiado para programas de caráter assistencialista e a legislação estrita, que condenava como usura toda ação concorrencial com as instituições financeiras convencionais"28. Sua adoção como política de geração de renda teria se tornado possível apenas após o controle inflacionário e

${ }^{27}$ M. Yunnus \& A. Jolis, O banqueiro dos pobres: a revolução do microcrédito, São Paulo, Ática, 2002.

${ }^{28}$ S. Parente, Microfinanças - saiba o que é um banco do povo, cit., p. 97. 
estabilização macroeconômica, em 1994, com o Plano Real. Somam-se ainda a esses fatores a situação econômica frágil das instituições microfinanceiras e os impedimentos legais e regulatórios a serem superados pelas instituições candidatas a atuar no segmento ${ }^{29}$.

De início, a criação de instituições microfinanceiras no país ocorreu de modo esparso, por vezes em parceria com algumas municipalidades e sob o financiamento e cooperação técnica de organizações e agências internacionais (como GTZ ${ }^{30}$, IPC ${ }^{31}$, Acción Internacional $^{32}$, Consultative Group to Assist the Poor $-\mathrm{CGAP}^{33}$, Banco Interamericano de Desenvolvimento - BID, por meio da Corporação Interamericana de Investimentos - IIC ${ }^{34}$, e Banco Mundial, por meio do International Finance Corporation - IFC $^{35}$ ). Algumas dessas iniciativas seguem brevemente pontuadas.

No ano de 1973, com o suporte de entidades empresariais, bancos locais e assistência técnica da Acción Intenacional e apoio de associações comerciais e federação das indústrias, foi criada na Grande Recife a União Nordestina de Assistência a Pequenas Organizações (Programa UNO, organização não-governamental), com o objetivo de conceder microcrédito e capacitar microempreendedores informais de Pernambuco e Bahia, com operações lastreadas em espécie de 'aval moral'. O programa, pioneiro no emprego de técnicas microfinanceiras na região, obteve visibilidade na América Latina e inspirou outras experiências em países como Peru e Bolívia. Sua repercussão atraiu investimentos do Banco Mundial e maior atenção do governo federal brasileiro, resultando na sua inserção no Projeto Polonordeste, e em investimentos da ordem de 120 milhões de dólares para projetos de irrigação, serviços de extensão agrícola, infra-estrutura e crédito. Entretanto, após dezoito anos de atividades, o programa desapareceu em 1991, “por não

\footnotetext{
${ }^{29}$ L. Goldmark, S. Pockross, D. Vechina, “A situação das microfinanças no Brasil”, Rio de Janeiro, BNDES, 2000.

${ }^{30}$ Organização governamental alemã de cooperação internacional.

${ }^{31}$ Internazional Projekt Consult, organização alemã.

32 Organização não governamental sem fins lucrativos especializada em microfinanças. Surgiu em 1961, e iniciou suas atividades com programas voltados para a redução da miséria em favelas de Caracas, na Venezuela. Hoje está presente em 18 países, inclusive no Brasil.

33 Consórcio de 33 agências de cooperação bilaterais e multilaterais que atua na pesquisa, capacitação e treinamento de instituições financeiras e microfinanceiras, gestores públicos, reguladores e auditores.

${ }^{34}$ Braço privado do BID.

${ }^{35}$ Braço privado do Banco Mundial, atua nas esferas de assistência técnica e investimentos diretos. Apóia iniciativas de microfinanças nos paises em desenvolvimento, especialmente no que tange à capacitação dos órgãos supervisores dos sistemas financeiros nacionais, criação do quadro regulatório propício ao desenvolvimento de políticas para as microfinanças.
} 
considerar a auto-sustentabilidade parte fundamental de suas políticas" ${ }^{36}$, ou seja, buscar a sustentabilidade financeira no longo prazo por meio ações e atividades tendentes a capitalizar o projeto.

Em 1982, a Associação Brasileira para o Desenvolvimento da Mulher - Banco da Mulher, passou a atuar no setor por meio da concessão de pequenos empréstimos a grupos solidários. Em 1989, passou a atuar com apoio do Fundo das Nações Unidas para a Infância (Unicef) e do BID. Atualmente é filiado ao Women's World Bank (WWB), e possui filiais em Rio Grande do Sul, Santa Catarina, Paraná, Rio de Janeiro, Minas Gerais, Bahia, Amapá e Amazonas.

A partir da atuação bem-sucedida de organizações não-governamentais colombianas e da Acción Internacional, em 1989 o Centro de Apoio aos Pequenos Empreendimentos Ana Terra (CEAPE/RS, constituído sob a forma de organização não governamental) passou a conceder pequenos empréstimos fundados na metodologia dos grupos solidários para pequenos empreendedores do setor informal. A Inter-American Foundation (IAF) e o BID forneceram recursos para a composição inicial de funding para o início de suas atividades. Em 1990, foi criada a Federação Nacional (FUNAPE), hoje chamada CEAPE Nacional. No decorrer da década de 90, a Rede CEAPE instalou unidades em Sergipe, Pernambuco, Paraíba, Bahia, Distrito Federal, Goiás, São Paulo, Espírito Santo, Piaúi e Pará. Sua participação no setor microfinanceiro seria inferior apenas à do Banco do Nordeste, contando com uma carteira de 17 milhões de reais e cerca de 23 mil clientes.

Há, ainda, nesse período, o surgimento de instituições circunscritas a determinados Estados, como a Instituição Comunitária de Crédito Portosol (1995), associação civil de direito privado sem fins lucrativos que conjuga esforços da prefeitura de Porto Alegre, governo do Rio Grande do Sul e entidades da sociedade civil; e como a associação sem fins lucrativos VivaCred (1996), criada por iniciativa da ONG Viva Rio, que obteve apoio técnico da consultoria alemã IPC e inicialmente financiamento do BID, e em momento posterior do Banco Fininvest. O VivaCred mantém convênios de cooperação e parcerias

36 M. Tomelin, “O microcrédito no Brasil”, Brasília, 2003, disponível em www.saa.unito.it/pdf/alfa/tomelin.pdf 
com o VivaRio, BNDES, BID, Instituto Brasileiro de Administração Municipal (Ibam), Secretaria Municipal do Trabalho do Rio de Janeiro e SEBRAE.

O BNDES, em 1996, passou a atuar no setor por meio do Programa Produtivo de Crédito Popular (PCPP), com a finalidade de disponibilizar linhas de crédito de baixo custo e a longo prazo para instituições de microcrédito nacionais. Em 1998, uma parceria financeira entre o BID e o BNDES (Programa de Desenvolvimento Institucional - PDI) permitiu que o segundo passasse a dispor de fundos para o fortalecimento institucional das entidades microfinanceiras em operação em diferentes cidades brasileiras. O PDI abrangia capacitação técnica para sistemas de informações gerenciais, operacionais e contábeis, metodologias de auditoria e rating, formação de recursos humanos e agentes de crédito. Dada sua importância para o desenvolvimento institucional do setor, o papel do BNDES será pormenorizado no Capítulo 3.

No ano de 1997, o Banco do Nordeste obteve apoio do Banco Mundial para iniciar sua bem-sucedida carteira de microcrédito, o CrediAmigo, maior programa para o financiamento produtivo urbano em curso no país. O BNB estabeleceu parcerias inicialmente com a Acción Internacional e em momento posterior com diferentes OSCIPs, o que conferiu ao programa uma estrutura administrativa enxuta, com baixos custos, atendimento localizado e personalizado por meio de agentes de crédito. O Programa CrediAmigo será analisado em detalhes no Capítulo 2, infra.

Observa-se que, de início, as microfinanças tiveram no Brasil um período de experimentação em que foi fundamental o papel de agências internacionais e organizações não-governamentais especializadas, por vezes em parceria com associações da sociedade civil, por vezes em parceria com o poder público local. Entretanto, sua consolidação no país carecia de um marco regulatório federal condizente com as necessidades do setor, vez que o Sistema Financeiro Nacional, concebido no contexto histórico da Reforma Bancária $^{37}$ levada a cabo como meta do Plano de Ação Econômica do Governo (PAEG,

\footnotetext{
37 “Em termos estruturais, a principal e mais relevante inovação da Lei 4.595/64 foi a de dotar o País, pela primeira vez, de um sistema financeiro, assim entendido como conjunto de órgãos atuando de maneira coordenada para alcançar um objetivo comum, desde então já definido, no seu art. $2^{\circ}$, como o do atingimento do progresso econômico e social do país" (S. Turczyn, O Sistema Financeiro Nacional e a Regulação Bancária, São Paulo: Editora Revista dos Tribunais, 2005, p. 131).
} 
1964-1966), não dispunha do aparato normativo necessário para a atuação de entidades microfinanceiras. Tal adaptação se fez necessária não apenas no Brasil:

“A participação de organização não-governamental sem fins lucrativos em iniciativas de microfinanças é uma pratica corriqueira há décadas, conforme demonstram os históricos descritos anteriormente. No entanto, o ordenamento jurídico de muitos países não permite que elas promovam atividades com características financeiras. Para tanto, existe um grande movimento na atualidade para adequação do direito, de maneira geral, e adaptação de normas, de maneira específica, à realidade das microfinanças. (...) A maioria das instituições que tem prestado esse tipo de serviço, por sua natureza filantrópica, são as organizações não-governamentais. Além disso, nas últimas décadas, as metodologias inovadoras para operação de serviços microfinanceiros foram criadas primordialmente por elas. (...)

No entanto, como normalmente elas não têm autorização legal para operar no setor financeiro, e os custos para a implementação dessas atividades são muito elevados, tornou-se necessária a criação de parâmetros legais para diminuir - ou eliminar - as barreiras econômicas dessa atividade, assim como criar condições favoráveis a novos entrantes nesse mercado." 38

A literatura internacional aponta que criação de instrumentos de regulação e supervisão específicos para o setor se tornou um imperativo a partir do momento que organizações não-governamentais prestadoras de serviços microfinanceiros passaram a crescer em termos numéricos, complexidade das operações realizadas, número de clientes e, ainda, transformar sua forma societária para ter maior proximidade da regulamentação financeira dos países ${ }^{39}$. Do ponto de vista dessas mesmas ONGs, o novo ambiente lhes confere a vantagem do reconhecimento e legitimidade perante o mercado financeiro, facilitando a tomada de recursos, na medida em que sua padronização, sob regras claras e já timbradas pelo costume, conquista a confiança de novos doadores e investidores. Do

\footnotetext{
${ }^{38}$ M. Monzoni, O impacto em renda do microcrédito, São Paulo, Editora Petrópolis, Centro de Estudos em Sustentabilidade - FGV-ESASP, 2008, p. 72.

39 "Transformation from a nongovernmental organization (NGO) to a deposit-taking financial-intermediary does not simply represent a change of legal status. When a microcredit organization becomes licensed and begins to offer voluntary savings services, a wholesale cultural and operational transformation is required, compelling a full understanding an appreciation of the changes that will occur within the organization as it transforms." J. Ledgerwood \& V. White (org.), Transforming Microfinance Institutions - providing full financial services to the poor, p. 67.
} 
ponto de vista dos órgãos reguladores, o maior controle de suas atividades pode ser traduzido em ganhos de segurança aos depositantes, aos investidores e ao sistema de pagamentos.

Os modelos regulatórios capazes de assegurar tal ambiente às instituições microfinanceiras, segundo a literatura internacional ${ }^{40}$, seriam baseados na: i) regulamentação bancária, ou inserto no sistema financeiro; ii) regulamentação específica para o setor, à parte do sistema financeiro, e iii) auto-regulação indireta, via participação conjunta das instituições na elaboração das normas a que se submetem. Suas vantagens e desvantagens podem ser resumidas da seguinte forma:

\begin{tabular}{|c|c|c|}
\hline $\begin{array}{c}\text { regulamentação } \\
\text { bancária }\end{array}$ & $\begin{array}{c}\text { regulamentação específica } \\
\text { para o setor }\end{array}$ & $\begin{array}{c}\text { auto-regulação } \\
\text { indireta }\end{array}$ \\
\hline 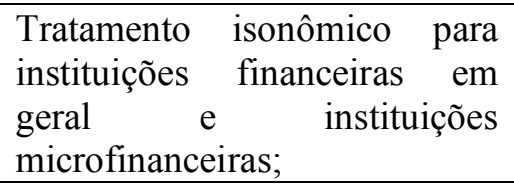 & $\begin{array}{l}\text { Subsistema normativo } \\
\text { específico e criado a partir de } \\
\text { suas particularidades, exclusão } \\
\text { do sistema financeiro nacional; }\end{array}$ & $\begin{array}{l}\text { Regras criadas pelas próprias } \\
\text { instituições, fiscalização de } \\
\text { suas atividades por espécie de } \\
\text { umbrella body; }\end{array}$ \\
\hline $\begin{array}{l}\text { desvantagens em relação à } \\
\text { desconsideração de suas } \\
\text { especificidades, como por ex., } \\
\text { requisitos de capital mínimo } \\
\text { para sua constituição; e }\end{array}$ & $\begin{array}{l}\text { desvantagens quanto às } \\
\text { restrições impostas para } \\
\text { captação de recursos junto ao } \\
\text { público, eventual dependência } \\
\text { de doadores e governo; e }\end{array}$ & $\begin{array}{l}\text { desvantagens quanto à } \\
\text { credibilidade, dada a ausência } \\
\text { de regulamentação } \\
\text { supervisão governamental; e }\end{array}$ \\
\hline $\begin{array}{l}\text { vantagens como o acesso a } \\
\text { facilidades restritas aos agentes } \\
\text { do sistema financeiro, como } \\
\text { por ex. operações de } \\
\text { redesconto. }\end{array}$ & $\begin{array}{l}\text { vantagens relativas à atuação } \\
\text { em subsistema próprio, sem } \\
\text { que seja necessária adaptação a } \\
\text { regras e exigências alienígenas. }\end{array}$ & $\begin{array}{l}\text { vantagens concernentes à } \\
\text { independência de sua atuação e } \\
\text { desvinculação da burocracia } \\
\text { estatal. }\end{array}$ \\
\hline
\end{tabular}

No Brasil, pode-se dizer que convivem os dois primeiros modelos de regulação. Há instituições que operam sob a regulamentação do Sistema Financeiro Nacional, como é o caso de sociedades de crédito ao microempreendedor e de cooperativas de crédito, e ainda carteiras especializadas das instituições bancárias. Outras, possuem regulamentação apartada, como é o caso de ONGs e OSCIPs registradas junto ao Ministério da Justiça. Ressalte-se, todavia, que tais formas jurídicas podem se entrecruzar e atuar conjuntamente, como é o caso de OSCIPs que detêm o controle societário de sociedades de crédito ao microempreendedor. Ou o caso de instituições bancárias que, no âmbito de suas carteiras crédito especializadas, se valem de parcerias com OSCIPs, que auxiliam a captação e

${ }^{40}$ R. P. Christen \& R. Rosenberg, "The rush to regulate: legal frameworks for microfinance", Washington D. C., CGAP, 1999; S. Staschen, "Regulation and supervision of microfinance institutions: the state of knowledge", Eschborn, GTZ, 1999. 
acompanhamento de seus tomadores de crédito. O modelo regulatório brasileiro, portanto, não pode ser resumido aos tipos estanques usualmente expostos na literatura internacional. Faz-se necessário para sua compreensão global, portanto, a revisão da produção normativa produzida tanto para instituições que atuam reguladas sob as características de um e outro modelo, e ainda as correlações pertinentes entre ambos.

O próximo tópico abordará, com mais detalhes, as características da legislação nacional e da regulamentação das microfinanças concebida pela atuação conjunta dos órgãos integrantes do Sistema Financeiro Nacional (especialmente CMN, BCB e BNDES), a partir do período de experimentação das microfinanças no país.

b) Arcabouço regulatório das microfinanças no Brasil

Para que as instituições microfinanceiras deixassem de ser apenas extensões de políticas sociais e tivessem acesso franqueado, principalmente, a fontes alternativas de financiamento que não apenas agências especializadas e poder público, o aprimoramento do marco regulatório e do nível técnico das próprias instituições para sua atuação junto ao mercado e ao público era fundamental. Impulsionar tal debate e articular medidas e políticas no plano federal foi papel inicialmente exercido pelo Conselho da Comunidade Solidária, a partir de 1995. Em 1997, o Conselho lançou a "Rodada de Interlocução Política de Geração de Emprego e Renda", da qual derivou o "Comitê Executivo do Marco Legal do Microcrédito", integrado por entidades do segmento, como SCMs, OSCIPs, cooperativas de crédito; e representantes do BCB, BNDES, Banco do Brasil, Caixa Econômica Federal e Banco do Nordeste. Posteriormente, foram organizados grupos de trabalho oficializados pelo Conselho Monetário Nacional (CMN) e coordenados pelo Ministério da Fazenda. As principais medidas que derivaram de seus esforços foram:

i) a Lei n. 9.790/99, ou Lei do Terceiro Setor, que inclui o microcrédito como uma das finalidades das Organizações Civis de Interesse Público (OSCIPs), permitindo que organizações não-governamentais atuassem com microcrédito sob essa específica forma jurídica e tivessem acesso a recursos públicos, mediante termos de parceria $^{41}$;

\footnotetext{
${ }^{41}$ As Medidas Provisórias n. 1.194 e n. 1.894 inicialmente estabeleceram as linhas gerais para sua atuação, posteriormente foram transformadas na MP n. 2.172-32/01 e Lei n. 10.194/01.
} 
ii) a Medida Provisória n. 2.172-32/01, que trata das estipulações usurárias em contratos, exclui as OSCIPs da incidência da Lei de Usura ${ }^{42}{ }_{-}^{43}$;

iii) a Lei n. 10.194/01, que criou as Sociedades de Crédito ao Microempreendedor (SCM), instituição privada com menor exigência de capital e trâmite burocrático mais célere, posteriormente regulamentada pelo Banco Central do Brasil (BCB); e

iv) autorização para que organizações não-governamentais constituídas sob a forma de OSCIP controlem instituições privadas com fins lucrativos constituídas sob a forma de SCM, de modo que as atividades da primeira possam ser contrabalanceadas pelos lucros da segunda.

O tópico 2.2, no Capítulo 2, a seguir, relativo aos agentes prestadores de serviços microfinanceiros, tratará de alguns detalhes desses diplomas normativos.

De fins da década de 90 até hoje, dois atores integrantes da administração pública federal são fundamentais ao fortalecimento institucional das microfinanças no país, o BNDES e o BCB. Enquanto o primeiro, por meio de parcerias com o BID, passou a investir em capacitação e financiamento de instituições microfinanceiras em operação, o segundo passou a promover estudos e debates sobre o arcabouço regulatório adequado para sua harmonização à legislação que estrutura nosso sistema financeiro.

No panorama institucional brasileiro das microfinanças, o BNDES poderia ser classificado como agente circunscrito ao que se denomina "instituição meso" ou de "segundo piso", que fornece capacitação técnica, e financiamento às instituições de "primeiro piso" (aquelas que prestam serviços microfinanceiros diretamente ao público). Assim, o BNDES acaba por atuar, em regra, junto às instituições microfinanceiras, prestando amparo quanto: i) ao custeio de sua fase inicial de operação ou ampliação do seu fundo rotativo de crédito; ii) à modernização tecnológica; iii) ao treinamento de agentes de crédito e pessoal administrativo, bem como de membros da comunidade e lideranças locais envolvidos diretamente com as atividades da instituição.

${ }^{42}$ Decreto 22.626/33, recepcionado pela ordem constitucional vigente como lei ordinária, proíbe, além da cobrança de juros a taxas superiores a $12 \%$ ao ano, a cobrança de juros compostos (juros sobre juros). Suas disposições, entretanto, não se aplicam às entidades reguladas no âmbito do Sistema Financeiro Nacional.

${ }^{43}$ Esta foi uma importante medida para a alavancagem do setor, na medida em que permite às instituições microfinanceiras operarem com taxas de juros livres e condizentes com as praticadas no mercado, e não com restrições quanto ao seu teto máximo, obtendo a remuneração adequada aos empréstimos que realiza. 
O SEBRAE, criado em 1972 com o objetivo de promover o desenvolvimento sustentável de empreendedores de pequeno porte, pode ser igualmente classificada uma instituição de segundo piso. Atua junto a microempreendedores por meio das chamadas "Unidades de Negócio e Gestão" espalhadas por todo o país. Desde outubro de 2001, com a criação de seu Programa de Apoio ao Segmento de Microcrédito, incentiva o desenvolvimento institucional do setor e fomenta parcerias que tendentes a complementar e multiplicar os recursos disponíveis para as instituições microfinanceiras brasileiras.

No que tange ao papel desempenhado pelo $\mathrm{CMN}$ e pelo $\mathrm{BCB}$ na estrutura normativa em vigor, a Lei n. 4.595/64, que dispõe sobre a política e as instituições monetárias, bancárias e creditícias, atribui ao $\mathrm{CMN}$ as funções de regulação e supervisão do Sistema Financeiro Nacional e, ao BCB, sua operacionalização. Dentre outras atividades a serem executadas pelo $\mathrm{BCB}$, destacam-se: exercer o controle do crédito sob todas as suas formas; exercer a fiscalização das instituições financeiras e aplicar as penalidades previstas; conceder autorização às mesmas, a fim de que possam funcionar no país (artigo 10 e incisos).

No que diz respeito especificamente à sua atuação regulatória no setor microfinanceiro, não tratado em capítulo específico pela lei, como mencionado supra, observa-se que o BCB, nos últimos anos, tem buscado aproximar o setor, de modo viável, aos padrões internacionais definidos pelas diretrizes do Commitee on Banking Regulations and Supervisory Practices, ou Comitê da Basiléia, composto pelos países membros do Grupo dos Dez (G-10) e representantes da Suíça e Luxemburgo.

Apesar de não possuir o status de autoridade bancária internacional e suas recomendações e diretrizes não possuírem força legal ou vinculante sequer para seus membros, a adesão aos seus princípios é verificável por todos os países que desejam integrar suas economias ao mercado financeiro internacional. $\mathrm{O}$ objetivo imediato de tais recomendações e diretrizes é o de reduzir o risco da insolvência bancária e para seus depositantes, com base em níveis mínimos de capital necessários à cobertura dos riscos assumidos. De forma mediata, impedir que uma crise sistêmica abale a confiança no sistema financeiro como um tudo e dê margem a quebras sucessivas. Segundo o Comitê, os pilares da solidez e segurança do sistema financeiro seriam três: i) requisitos mínimos de 
capital, ii) procedimentos tendentes à supervisão bancária, e iii) uso efetivo da disciplina de mercado.

Em 1992, o Brasil passou a adotar seus mecanismos de supervisão e fiscalização bancária (Resolução 1.942/92 do BCB) e, em 1997, os chamados "25 princípios para uma supervisão bancária eficaz" (Resolução 2.554/98 do BCB), que estabelecem, dentre outros objetivos, o desenvolvimento de: i) políticas e práticas operacionais destinadas à avaliação de qualidade de ativos; ii) sistemas gerenciais aptos a identificar eventual concentração de riscos; iii) regras rígidas de identificação de clientes, com a finalidade de impedir fraudes e ilegalidades.

A princípio, tais diretrizes da Basiléia poderiam ser tomadas como restritivas à prestação de serviços microfinanceiros, na medida em que certas exigências quanto às contrapartidas para a prestação de serviços financeiros pelas instituições bancárias inibiriam sua disponibilização ao público de menor poder aquisitivo ou com poucas garantias a oferecer.

Apesar do grande número de clientes potencialmente atingidos, a participação das instituições microfinanceiras no sistema bancário e creditício como um todo é pequena, em razão do baixo valor das transações realizadas. Esta peculiaridade torna a ocorrência de uma crise sistêmica uma possibilidade extremamente remota. Todavia, é inegável que a insolvência de uma instituição de microcrédito poderia gerar uma crise de confiança no setor, provocando a fuga em cadeia de clientes e investimentos, ocasionando o que se tornou corrente denominar "crise subsistêmica"44.

Os controles prudenciais utilizados na regulação de instituições microfinanceiras, portanto, devem ter por fim garantir que seus clientes e as demais instituições estão protegidos de crises geradas por eventuais quebras. Entretanto, na transposição das diretrizes da Basiléia às instituições microfinanceiras devem ser guardadas as devidas proporções. Restrições adequadas às instituições financeiras tradicionais, se imediatamente aplicadas às microfinanceiras, podem acabar por inviabilizar suas atividades.

\footnotetext{
${ }^{44}$ R. P. Christen \& R. Rosenberg, "The rush to regulate: legal frameworks for microfinance", Washington D. C., CGAP, 1999; T. Jansson 7 M. Werner, "Finance regulation and its significance for microfinance in Latin America and the Caribbean, Washington D. C., Inter-American Development Bank, 1997.
} 
Assim, as exigências de capital mínimo e a ponderação de riscos de ativos tal como definidas internacionalmente podem não ser pertinentes ao setor microfinanceiro, levandose em conta os altos custos unitários dos seus empréstimos (sobre os quais recaem os riscos da ausência de garantias reais e as despesas com capacitação e educação financeira de seus clientes, por exemplo). Cabe à autoridade reguladora, nesse sentido, dosar qual a medida do remédio tradicionalmente aplicado às bancas comerciais a ser ministrada às instituições microfinanceiras, para que não se torne veneno. A exemplo do que ocorreu com o tratamento das sociedades de crédito ao microempreendedor e das cooperativas de crédito (tratadas com certa minúcia no Capítulo 2, a seguir), o BCB demonstra buscar as respostas adequadas a tais instituições no plano regulamentar ${ }^{45}$.

No plano infra-legal, a regulamentação das microfinanças no decorrer dos últimos anos teve avanços significativos, como por exemplo no que diz respeito à criação das contas bancárias simplificadas, em meados de 2003, pelas Resoluções 3.104/03 ${ }^{46}$ e 3.113/03, ambas do Conselho Monetário Nacional, que tornaram menores as exigências para abertura de contas simplificadas e liberou-as da cobrança de tarifas. Anteriormente a essas medidas, o Banco Mundial realizara extensa pesquisa no país, divulgada no portal especializado em microfinanças The Microfinance Gateway ${ }^{47}$, mantido pelo Grupo Consultivo para a Assistência aos Pobres, com números conclusivos no que dizia respeito aos entraves para a abertura de contas em bancos pelos mais pobres e as dificuldades de seu acesso a serviços financeiros ${ }^{48}$. Realidade semelhante era apontada por pesquisas nacionais: segundo a Pesquisa Nacional por Amostra de Domicílio (PNAD) de 1999, realizada pelo IBGE, $70 \%$ da população brasileira estaria excluída do sistema financeiro formal. Segundo números recentes apresentados pelo governo federal, essa realidade começa a se transformar por conta das menores exigências burocráticas para a abertura de

\footnotetext{
${ }^{45}$ M. M. Soares e A. D. De Melo Sobrinho, Microfinanças - O papel do Banco Central do Brasil e a importância do cooperativismo de crédito, Brasília, Banco Central do Brasil, 2007, p. 85.

${ }^{46}$ A conta simplificada é de destinação exclusiva a pessoas físicas, não titulares de conta de depósitos à vista, apresentação tão somente de inscrição no Cadastro de Pessoas Físicas (CPF) para abertura da conta, há fornecimento apenas de cartão magnético para sua movimentação. O limite máximo de saldo que pode ser mantido na conta a qualquer tempo é de $\mathrm{R} \$ 1.000,00$, bem como para o somatório dos depósitos nela efetuados em cada mês.

${ }^{47}$ www.microfinancegateway.com

${ }^{48}$ A. Kumar . Access to financial services in Brazil-Directions in Development, The World Bank, 2005, pp. 191-192.
} 
contas bancárias: em 30 de julho de 2008, os maiores bancos públicos brasileiros ${ }^{49}$ somados possuíam o total de 8.658.337 contas correntes simplificadas abertas, dentre as quais 5.074.321 eram tidas como contas ativas ${ }^{50}$. O quadro a seguir resume a evolução da bancarização da população brasileira:

\begin{tabular}{lcccccccc}
\hline \multirow{2}{*}{\multicolumn{1}{c}{ Tipo }} & \multicolumn{9}{c}{ Período } & \multicolumn{2}{c}{ Variação } \\
\cline { 2 - 9 } & 2001 & 2002 & 2003 & 2004 & 2005 & 2006 & 2007 & $01-07$ \\
\hline conta corrente & 43,3 & 45,6 & 45,9 & 50,4 & 53,7 & 59,5 & 61,9 & $42,9 \%$ \\
poupança & 51,2 & 58,2 & 62,4 & 67,9 & 70,8 & 76,8 & 82,1 & $60,4 \%$ \\
conta simplificada & - & - & - & 4,0 & 6,3 & 6,8 & 7,6 & $89,6 \%$ \\
\hline bancarizados & 94,5 & 103,8 & 108,3 & 122,3 & 130,8 & 143,1 & 151,6 & $60,4 \%$ \\
\hline População & 172,4 & 174,6 & 176,9 & 179,1 & 181,3 & 183,6 & 185,7 & $7,7 \%$ \\
\hline
\end{tabular}

Valores em milhões. Não foi levada em conta a titularidade de mais de uma conta por indivíduo. Fonte: $\mathrm{BCB}$

Como visto até o momento, apesar do estudo das microfinanças no Brasil, indubitavelmente, requerer constantes consultas à legislação e regulamentação produzida no âmbito do Sistema Financeiro Nacional, há quem vincule suas atividades de forma imediata aos princípios fundamentais estabelecidos na Constituição Federal:

"Os direitos fundamentais estabelecidos pela Constituição Federal têm como motivo precípuo o combate a toda sorte de exclusão social e a garantia de insumos materiais e direitos (subjetivos) a todo indivíduo, constituindo-se em seu patrimônio mínimo que ao país e sua sociedade, como um todo, cabe assegurar. Contudo, a exclusão social se manifesta das mais variadas formas. Concomitantemente aos direitos tão básicos como saúde e educação, consagrados nos países de tradição européia ocidental por séculos de história, somam-se outros, que modernamente se demonstram essenciais à compreensão do fenômeno da exclusão social e seu combate.

$\mathrm{O}$ acesso ao crédito, da mesma forma que o acesso ao meios de telecomunicação, se não configuram-se imediatamente como um dos direitos pétreos, são parcelas essenciais da existência daqueles. É uma das fronteiras que se não forem transpostas, impedirão ao indivíduo e à

${ }^{49}$ Caixa Econômica Federal, Banco do Brasil, Banco Popular do Brasil, Banco do Nordeste e Banco da Amazônia.

${ }^{50}$ Fonte: Ministério da Fazenda e Banco Central do Brasil. 
sociedade como um todo o gozo de seus direitos fundamentais, a garantia da constituição e manutenção de um 'patrimônio cidadão mínimo'. Enquadrase, portanto, intrínseca e precipuamente nos direitos pétreos da Constituição Federal e da República Federativa do Brasil."

Ressalte-se, entretanto, que tal vinculação não é considerada tão óbvia pela unanimidade dos intérpretes. No contexto de uma Constituição (extremamente) garantista como a brasileira, não são poucos os críticos da linha interpretativa supra. Argumenta-se, e com alguma razão, em virtude da amplitude do artigo $5^{\circ}$ da Constituição Federal de 1988, relativo ao rol dos direitos e garantias fundamentais, que a cobertura constitucional de direitos seria tão vasta a ponto de se tornar possível a identificação retórica e reivindicação de praticamente qualquer direito ou garantia como fundamentais à dignidade humana. Nos limites possíveis investigados pela presente dissertação, defende-se, quanto a este ponto, que para tornar possível a vinculação entre o acesso ao crédito e a manutenção de um 'patrimônio cidadão mínimo' como condição essencial para o gozo de direitos fundamentais, há que se demonstrar, de forma pontual e concreta, a direta vinculação de formas jurídicas específicas ao seu uso instrumental para alcançar tais finalidades, não restando suficiente, ainda que não totalmente desprovida de valor, a possível correlação operada no plano da hermenêutica constitucional. Veja-se, nesse sentido, sobre a submissão de formas jurídicas a princípios constitucionais, ou a utilização instrumental de agentes econômicos atuantes no mercado financeiro para atingir finalidades de políticas públicas de cunho social, o Capítulo 2, item 2.2.

${ }^{51}$ P. H. Martins, “A regulamentação da área de microfinanças”, Rio de Janeiro, Rits, Rede de Informações $\begin{array}{llllll}\text { para } & 0 & \text { Terceiro } & \text { Setor, } & 2002 . & \text { Disponível }\end{array}$ www.rits.org.br/legislacao teste/lg_testes/lg_tmes_abril2002.cfm. Os dispositivos constitucionais em referência, citados pelo autor, seriam os seguintes: Art. $1^{\circ}$ A República Federativa do Brasil (...) tem como fundamentos: (...) III - a dignidade da pessoa humana; IV - os valores sociais do trabalho e da livre iniciativa; Art. $3^{\circ}$ Constituem objetivos fundamentais da República Federativa do Brasil: I - construir uma sociedade livre, justa e solidária; II - garantir o desenvolvimento nacional; III - erradicar a pobreza e a marginalização e reduzir as desigualdades sociais e regionais; IV - promover o bem de todos, sem preconceitos de origem, raça, sexo, cor, idade e quaisquer outras formas de discriminação; Art. 170. A ordem econômica, fundada na valorização do trabalho humano e na livre iniciativa, tem por fim assegurar a todos existência digna, conforme os ditames da justiça social, observados os seguintes princípios: (...) III - função social da propriedade; (...) VII - redução das desigualdades regionais e sociais; VIII - busca do pleno emprego; IX tratamento favorecido para as empresas de pequeno porte constituídas sob as leis brasileiras e que tenham sua sede e administração no País; Art. 179. A União, os Estados, o Distrito Federal e os Municípios dispensarão às microempresas e às empresas de pequeno porte, assim definidas em lei, tratamento jurídico diferenciado, visando a incentivá-las pela simplificação de suas obrigações administrativas, tributárias, previdenciárias e creditícias, ou pela eliminação ou redução destas por meio de lei; Art. 192. O sistema financeiro nacional, estruturado de forma a promover o desenvolvimento equilibrado do País e a servir aos interesses da coletividade, será regulado em lei complementar, que disporá, inclusive, sobre; Art. 193. A ordem social tem como base o primado do trabalho, e como objetivo o bem-estar e a justiça sociais. 
Permanece a indagação, todavia, de qual o enquadramento normativo cabível às relações travadas no universo das microfinanças. À primeira vista, para o direito, poderiam ser tratados como excludentes a esfera das relações econômicas e de mercado, atinente aos bens e direitos patrimoniais disponíveis, e a esfera dos direitos e garantias fundamentais. E, ainda que em discurso, tais esferas sejam consideradas conciliáveis, há questões de ordem prática apresentadas pelo nosso sistema jurídico em vigor que requerem, no mínimo, alguma criatividade de nossos operadores. Por exemplo, a resposta à pergunta de qual seria o aparato regulatório e fiscalizador adequado às microfinanças no Brasil. A questão, imposta por um sistema jurídico estruturado sob bases que por vezes ainda permitem a oposição entre o público (ou direitos e garantias fundamentais) ao privado (ou direitos individuais disponíveis e garantias patrimoniais) oculta, na verdade, diferentes concepções do papel a ser desempenhado pelo sistema financeiro na nossa sociedade.

Tome-se, como exemplo, a longa e árdua discussão que recentemente envolveu instituições bancárias, Ministério Público e órgãos de defesa do consumidor quanto à submissão da prestação de serviços financeiros à legislação consumerista. O embate, ao fim solucionado pelo Supremo Tribunal Federal em favor das teses consumeristas dizia respeito, essencialmente, à recusa das instituições bancárias em reconhecer direitos definidos no Código de Defesa do Consumidor (CDC) aos seus clientes, em suma garantias condizentes ao maior rigor quanto à qualidade da prestação de serviços bancários, das informações postas à disposição de seus clientes, e ao reconhecimento de responsabilidade das instituições financeiras quanto à desobediência de regras protetivas consubstanciadas no $\mathrm{CDC}^{52}$. Dentre os principais argumentos levados ao STF pela Confederação Nacional do Sistema Financeiro, entidade que congrega instituições bancárias em operação no país, destaca-se, para o presente estudo, aquele pertinente à colisão ou antinomia gerada pela aplicação concomitante das normas reguladoras do Sistema Financeiro Nacional e legislação consumerista, vez que haveria uma distinção implícita na Constituição Federal entre consumidor e cliente de instituição financeira. $\mathrm{O}$ fundamento para esse argumento poderia ser resumido pelo fato de que o artigo 170 da

\footnotetext{
${ }^{52}$ Ação Direta de Inconstitucionalidade n. 2.591-1/Distrito Federal, proposta pela Confederação Nacional do Sistema Financeiro e julgada improcedente pelo Plenário do STF em 07 de junho de 2006, que decidiu: "As instituições financeiras estão, todas elas, alcançadas pela incidência das normas veiculadas pelo Código de Defesa do Consumidor. 'Consumidor', para os efeitos do Código de Defesa do Consumidor, é toda pessoa física ou jurídica que utiliza, como destinatário final, atividade bancária, financeira e de crédito". Inteiro teor disponível in www.stf.jus.br.
} 
Constituição Federal, que consagra o princípio da defesa do consumidor, encontra-se topograficamente localizado no capítulo da "Ordem Econômica", restando em capítulo diverso a disciplina do Sistema Financeiro Nacional (artigo 192, regulado por lei complementar própria). Some-se a isto que as regras estabelecidas pelo legislador ordinário no CDC teriam onerado, em demasia, as instituições bancárias com o conjunto de obrigações previstas na Lei n. 8.078/90, incompatíveis com as peculiaridades do setor financeiro. Ademais, segundo Confederação Nacional do Sistema Financeiro, o aspecto material das operações celebradas no sistema financeiro (como a concessão de crédito, por ex.) seria inconciliável com a proteção consumerista. $\mathrm{O}$ argumento obedece à lógica segundo a qual os bens e serviços disponibilizados pelas instituições bancárias estariam adstritos tão somente à esfera das relações patrimoniais disponíveis (e, consequentemente, para as quais seria bem-vinda apenas a incidência da legislação civil e penal), fora do alcance da legislação que remete à proteção de direitos fundamentais do cidadão.

O julgamento da ação constitucional considerou, de toda sorte, que a aplicação do princípio constitucional de proteção do consumidor $\left(\mathrm{CF} / 88\right.$, art. $5^{\circ}, \mathrm{XXXII}$, e $\mathrm{CF} / 88$, art. $170, \mathrm{~V}$ ) e sua legislação correlata (no caso em tela, especificamente o $\mathrm{CDC}$, artigo $3^{\circ}, \S$ $2^{053}$ ) não interferem na estrutura institucional do Sistema Financeiro Nacional e nas operações típicas das instituições financeiras no curso da intermediação monetária, reguladas pela lei complementar prevista no artigo 192, da Constituição Federal. Possível, portanto, que o CDC disponha sobre aspectos do relacionamento entre clientes e instituições bancárias que digam respeito a abusos e fraudes contra o consumidor (normas de conduta) sem interferir na esfera de incidência da Lei 4.595/64 (normas de $\operatorname{organização)~}^{54}$. Não haveria, portanto, motivo para se cogitar da exclusão material entre os diplomas normativos. Ao revés, devem ser consideradas as influências recíprocas dos mesmos regramentos sobre uma mesma realidade, a relação estabelecida na contratação de

\footnotetext{
$53 \mathrm{CDC}$, Art. $3^{\circ}, \S 2^{\circ}$ : "Fornecedor é toda pessoa física ou jurídica, pública ou privada, nacional ou estrangeira, bem como os entes despersonalizados, que desenvolvem atividades de produção, montagem, criação, construção, transformação, importação, exportação, distribuição ou comercialização de produtos ou prestação de serviços (...) $\S 2^{\circ}$ Serviço é qualquer atividade fornecida no mercado de consumo, mediante remuneração, inclusive as de natureza bancária, financeira, de crédito e securitária, salvo as decorrentes das relações de caráter trabalhista".

${ }^{54}$ Neste ponto, conveniente frisar, como o fez o Ministro Joaquim Barbosa por ocasião de seu voto na ADI $n$. 2.591-1/DF, "caso se pretenda aplicar as normas do CDC no sentido de reger o sistema financeiro, tal equívoco deve ser combatido pelos instrumentos adequados".
} 
serviços bancários, financeiros e de crédito por pessoas físicas e jurídicas que utilizem esses serviços como destinatários finais ${ }^{55}$.

Em verdade, o que não transparece de modo claro no julgamento da ação é que os limites claros entre o que se pode chamar "influências recíprocas" e invasão de esfera de competência das legislações em comento é algo verificável apenas no exame dos casos concretos que surgirem a partir da sua aplicação concomitante a conflitos originados na prestação desses serviços. Neste ponto, adquire relevo outra conseqüência do reconhecimento da incidência do CDC a tais relações: tornam-se coadjuvantes na fiscalização da conduta das instituições bancárias, no que tange às relações com seus clientes, outros atores com diferentes pontos de vista, que não apenas os integrantes do Sistema Financeiro Nacional e o tradicional enfoque das transações financeiras sob a ótica dos direitos patrimoniais disponíveis. Assim, o Ministério Público e as associações legalmente constituídas para defender interesses e direitos decorrentes das relações de consumo passam a participar efetivamente das discussões acerca das medidas necessárias e pertinentes ao aprimoramento da prestação de serviços financeiros ao público consumidor.

O exemplo do que ocorreu no caso das discussões sobre a aplicação do CDC às relações entre instituições bancárias e seus clientes ilustra a necessidade dos intérpretes e operadores do direito passarem a considerar a proteção do consumidor e do cidadão em esferas antes tidas por salvaguardadas apenas pela legislação protetiva dos direitos patrimoniais disponíveis. Não se quer afirmar, com isto, que a proteção ao indivíduo possa ser estendida ao ponto de, como argumentou a Confederação Nacional do Sistema Financeiro na ação constitucional em tela, colocar em risco a segurança jurídica e o respeito aos contratos, “condições de um sistema saudável”. Reconhece-se, apenas, como expressou o texto supra citado, a importância da aplicação de normas aptas a buscar "a garantia da constituição e manutenção de um patrimônio cidadão mínimo" que, modernamente, passa pela disposição dos instrumentos hábeis a preservar os valores frutos do trabalho. Importa ainda frisar que o caso sob análise em momento algum tratou da disciplina normativa dada às microfinanças, circunscrevendo suas discussões às relações entre instituições financeiras e a clientela que por regra tem recursos suficientes para se valer dos serviços tradicionalmente oferecidos pelos bancos. Entretanto, para fins do

\footnotetext{
${ }^{55}$ V. voto do Ministro Joaquim Barbosa na ação.
} 
presente estudo, o resultado do julgamento da ação e os debates suscitados são reveladores das novas balizas que passam a condicionar o intérprete no exame jurídico da prestação de serviços financeiros e que influenciam, sem dúvida, o olhar sobre o arcabouço legal das microfinanças no Brasil. Na seqüência, o presente estudo debruça-se sobre a evolução pontual das normas específicas para o setor e finalmente sobre as formas jurídicas hoje à disposição dos agentes microfinanceiros, oportunidade em que tal arcabouço normativo pode ser melhor detalhado.

c) Sumário da evolução normativa e institucional

A legislação pertinente à prestação de serviços microfinanceiros pode ser dividida didaticamente em cinco períodos, bem como sua evolução institucional pode ser sumarizada do seguinte modo ${ }^{56}$ :

\section{De 1972 a 1988:}

- no meio urbano, predomínio de redes alternativas organizadas por ONG's;

- no meio rural, predomínio de fundos rotativos (informais);

- gestão administrativa com enfoque no objetivo do financiamento e não no retorno do crédito.

\section{De 1989 a 1997:}

- municipalidades como agentes do microcrédito, seja indiretamente, por meio de associações com associações civis e/ou agências especializadas; ou diretamente, por meio da constituição de programas e/ou organizações para prestação de serviços a microempreendedores (Bancos do Povo);

- expansão do cooperativismo de crédito urbano, disciplina dos bancos cooperativos pela Resolução CMN n. 2.193/95;

- constituição de sistemas alternativos de cooperativas de crédito no âmbito rural.

De 1998 a 2002:

- a Lei n. 9.790/99, e sua correlata regulamentação, o Decreto n. 3.100/99, dispõem sobre os requisitos a serem preenchidos pelas pessoas jurídicas de direito privado sem lucrativos

\footnotetext{
${ }^{56}$ Fonte: Ministério da Fazenda, www.fazenda.gov.br .
} 
para sua qualificação como OSCIPs, regras de autorização, funcionamento e supervisão ${ }^{57}$; - a Resolução CMN n. 2.627/99, posteriormente revogada pela Resolução CMN n. 2.874/01 e, finalmente a Lei n. 10.194/01, instituíram em nosso ordenamento as SCM, sua forma de constituição, funcionamento e supervisão ${ }^{58}$

- reedição, em 1999, da MP n. 1.914-4, que tratou da estipulação de juros e apresentou soluções adequadas aos diferentes formatos jurídicos de instituições microfinanceiras, excluindo OSCIPs e SCMs de seu alcance, permitindo que tais entes pratiquem taxas de juros livres ${ }^{59}$;

- bancos cooperativos passaram a contratar operações de crédito rural subvencionadas pela União, nos termos da Lei n. 9.848/99;

- alterações na regulamentação dos bancos cooperativos, aproximando-os dos demais bancos comerciais ${ }^{60}$;

- autorização, pela Resolução CMN n. 3.188/04, para que os bancos cooperativos captassem depósitos de poupança rural;

- permissão para o funcionamento de cooperativas crédito de microempreendedores ${ }^{61}$;

- Programa de Microcrédito do BNDES, com as finalidades de financiamento e pesquisas para o desenvolvimento institucional do segmento;

- Programa CrediAmigo do Banco do Nordeste;

- regulamentação para atuação dos correspondentes bancários ${ }^{62}$;

- no período, predominaram as instituições de microcrédito ainda focadas tão somente no crédito, sem o fornecimento de outros serviços microfinanceiros, havendo pouca ou nenhuma relação entre estas instituições e as instituições bancárias (exceto cooperativas).

De 2003 a 2005 :

- criação do Banco Popular do Brasil (Lei n. 10.738/03) e das contas bancárias simplificadas ${ }^{63}$;

\footnotetext{
${ }^{57}$ São ainda aplicáveis às OSCIPs as Medidas Provisórias n. 2.143-33/01 e n. 2.113-32/01, e Portarias do Ministério da Justiça n. 361/99 e n. 256/02.

${ }^{58}$ Dentre os principais normativos infra-legais que regem as SCMs, destacam-se a Circular BCB n. 2.964/00, sobre demonstrações financeiras, a Carta Circular BCB n. 2.898/00, sobre padrões contábeis, a Circular BCB n. 3.166/02, sobre prestação de informações à Central de Risco de Crédito para as SCMs, e a Circular BCB n. 3.182/03, sobre transferência de controle societário, reorganização societária e instalação de postos de atendimento ao microempreendedor.

${ }^{59}$ Para o tratamento dispensado a cada uma das formas jurídicas, v. o Capítulo 2, item 2.2.

${ }^{60}$ Resolução do Conselho Monetário Nacional n. 2.788/00.

${ }^{61}$ Resolução do Conselho Monetário Nacional n. 3.058/02.

${ }^{62}$ Resolução do Conselho Monetário Nacional n. 2.707/00.

${ }^{63}$ Resolução do Conselho Monetário Nacional n. 3.211/04.
} 
- associação do crédito à prestação de outros serviços microfinanceiros à população de baixa renda por meio dos bancos cooperativos ${ }^{64}$;

- após longa experimentação e amadurecimento institucional, apoio do governo federal à flexibilização normativa para o cooperativismo de crédito com a permissão para a criação de cooperativas de livre admissão de $\operatorname{associados}^{65}$;

- regulamentação tendente a aumentar o número de correspondentes bancários e dos tipos de serviços por eles prestados ${ }^{66}$;

- legislação atinente ao crédito consignado ${ }^{67}$;

- ampliação e consolidação do Programa CrediAmigo.

\section{A partir de 2005:}

- criação do Programa de Microcrédito Produtivo Orientado, Lei n. 11.110/05 ${ }^{68}$, incluindo a regulamentação para o repasse de recursos dos bancos para instituições de microcrédito (depósitos especiais e Fundo de Assistência do Trabalhador);

- aproximação entre instituições financeiras tradicionais e instituições microfinanceiras, vinculando outros serviços financeiros ao microcrédito produtivo;

- viabilização de fundos de aval para as instituições de microcrédito;

- desenvolvimento de projetos de desenvolvimento institucional focados na articulação entre instituições de microcrédito e na padronização de modelos contábeis.

Conforme a cisão proposta (item 1.3, supra), os agentes prestadores de serviços microfinanceiros podem ser divididos i) entre aqueles que predominantemente perseguem lucro com o desenvolvimento de suas atividades, ii) e aqueles que, de alguma forma, são vinculados a políticas públicas geradoras de trabalho e renda, sem buscar o lucro como fim último de sua existência, mas como meio para garantir sua auto-sustentabilidade.

Dentre os primeiros, podemos identificar as instituições financeiras e as sociedades de crédito ao microempreendedor, autorizadas a funcionar pelo $\mathrm{BCB}$, sob o controle de qualquer pessoa física ou jurídica.

\footnotetext{
${ }^{64}$ Além da Resolução do Conselho Monetário Nacional n. 2.788/00, foi editada a n. 3.188/04.

${ }^{65}$ Lei n. 10.865/04 e Resolução do Conselho Monetário Nacional n. 3.106/03.

${ }^{66}$ Resoluções do Conselho Monetário Nacional n. 3.110/03 e n. 3.156/03.

${ }^{67}$ Além da já existente Resolução do Conselho Monetário Nacional n. 2.718/00, foram editadas a Lei n. 10.820/03, e o Decreto n. 4.961/04.

${ }^{68}$ Decreto n. 5.288/04, Resolução do Conselho Monetário Nacional n. 3.310/05 e Resolução Codefat n. $449 / 05$.
} 
Os demais são organizados sob as mais diversas formas jurídicas: sob a forma de entes personalizados, podem ser citados bancos públicos, organizações nãogovernamentais, organizações da sociedade civil de interesse público registradas no Ministério da Justiça, e cooperativas de crédito. Sob a forma despersonalizada, fundos públicos estaduais ou municipais (bancos do povo), administrados por autarquias, departamentos ou outras formas previstas em lei, em parceria ou não com associações da sociedade civil ou agências internacionais especializadas em microfinanças.

Como visto, podem ser identificados na legislação brasileira distintas formas jurídicas aptos a viabilizar a prestação de serviços microfinanceiros. Aparentemente, as características do agente e a finalidade a ser atingida pelo mesmo são os principais condicionantes da forma jurídica a ser adotada. Com essa afirmação não se quer dizer, por exemplo, que uma instituição microfinanceira organizada comunitariamente não seja capaz de gerar recursos além do mínimo necessário para sua auto-sustentabilidade: poderá fazêlo sem que com isso sua finalidade precípua, a de promover melhorias para o bem-estar local, seja prejudicada ou colocada em segundo plano. Do mesmo modo, não se quer dizer que programas de microcrédito conduzidos por bancos privados sejam incapazes de alavancar melhorias em comunidades carentes. Ambas são conseqüências que, mesmo colateralmente atingidas, não podem ser ignoradas ou ter seu valor menosprezado. Entretanto, quanto às atividades desempenhadas por instituições e programas, não se pode cobrar ou sequer esperar como resultados óbvios aqueles que não constituem sua razão de ser. Desse modo, o olhar a ser dirigido sobre as diferentes experiências em prestação de serviços microfinanceiros deve levar em conta, além de tão somente números, que podem ser grandes ou pequenos, a depender do poder econômico dos agentes envolvidos, a capacidade de realizar a finalidade a que se destinam.

Por outro lado, algumas dessas formas e a regulamentação a que se submetem podem acarretar maiores ou menores dificuldades e custos para seus fundadores. As exigências legais, burocráticas e de recursos financeiros a serem preenchidas por algumas delas podem inviabilizar sua constituição ou mesmo determinar seu encerramento prematuro, a depender do agente que a pretenda utilizar. Que uma organização sem fins lucrativos não possua capacidade econômica e técnica para constituir uma instituição bancária varejista nos moldes da Lei 4.595/64 pode ser óbvio, mas que a mesma não consiga organizar uma instituição microfinanceira nos moldes das formas jurídicas 
específicas para atender ao fim de prover serviços financeiros adequados e sustentáveis para a população de baixa renda pode ser, de certo modo, indicativo de que essa mesma forma jurídica não atende plenamente a finalidade a que se destina, ou que a regulamentação extensa, minuciosa e muitas vezes confusa não sinaliza de forma clara quais os caminhos a serem seguidos. Há uma diferença fundamental entre as duas situações: os requisitos de capacidade técnica e econômica para constituir uma instituição financeira nos moldes da Lei 4.595/64 e da Lei 6.404/76 revelam que o sistema financeiro nacional destina-lhe controles à altura do seu impacto na economia nacional e dos riscos que pode vir a causar à poupança popular, enquanto que, por outro lado, as organizações civis sem fins lucrativos que criticam a obscuridade do marco regulatório para as microfinanças no Brasil podem ter de fato à sua frente entraves jurídicos e burocráticos tais que dificultem ou mesmo inviabilizem sua constituição e regular funcionamento para a persecução de seus objetivos.

\subsection{Dilemas e debates}

Por fim, no encerramento deste capítulo sobre o ambiente normativo das microfinanças, cumpre mencionar algumas discussões presenciadas durante a pesquisa realizada, ainda que não se pretenda apresentar respostas para os problemas que apresentam.

A primeira delas diz respeito à afirmação, por representantes do governo federal, de que o marco regulatório para as microfinanças no país estaria pronto e acabado, à espera da ousadia e iniciativa das entidades microfinanceiras ${ }^{69}$. Podem, entretanto, serem citadas algumas percepções em sentido contrário. Há críticas no sentido de que o marco regulatório das OSCIPs seria insuficiente, e que a regulamentação das atividades dessas entidades microfinanceiras não seria clara, muitas vezes confusa, e de difícil compreensão pelas entidades, o que de fato acaba por atingir especialmente aquelas de pequeno porte $\mathrm{e}$ atuação essencialmente comunitária. Haveria ainda extrema dificuldade em acessar recursos financeiros internos, e as condições para parcerias internacionais ainda não seriam

${ }^{69}$ Posicionamento defendido por representantes do Ministério da Fazenda e do Banco Central do Brasil durante o VII Seminário BACEN Microfinanças realizado em Belo Horizonte entre os dias 29 de setembro e $1^{\circ}$ de outubro de 2008. 
adequadas para as entidades brasileiras ${ }^{70}$. Ver, no Capítulo 2, item 2.2, b.1, possível resposta à questão, formulada por estudo realizado por representantes do BCB.

Em segundo lugar, embora sem grandes repercussões e resultados, em 2007 foi apresentada à Câmara Dos Deputados proposta legislativa em franca oposição à regulação das microfinanças no âmbito do Sistema Financeiro Nacional, o Projeto de Lei Complementar 93/2007, que trata da regulação das iniciativas comunitárias e locais de organização e prestação de serviços microfinanceiros. Ainda que tal projeto de lei não prospere, a iniciativa em si é reveladora de vozes que se opõem à centralização da regulação de setor significativo das microfinanças pelo $\mathrm{BCB}$, por acreditar que o órgão regulador não apresente a sensibilidade necessária às especificidades do setor, e que sua supervisão estaria melhor a cargo de órgãos especializados na elaboração de políticas de cunho social.

Mais do que buscar meios para comprovar que um ou outro lado apresenta melhores argumentos a seu favor ou em desfavor do outro, importou à presente pesquisa perceber seus reflexos sobre o ambiente normativo criado a partir de intensos debates entre autoridade reguladora, grupos ministeriais e entidades microfinanceiras. O interesse em acompanhar tais discussões, portanto, não procurou encontrar vencedores ou perdedores.

Especificamente quanto à afirmação sobre a falta de clareza do marco regulatório, há que se ponderar a existência de extensa lista de normativos e minuciosos regulamentos concebidos a partir dos anos 2000, sua sucessão intermitente e substituição em curtos períodos, capaz de provocar, mesmo aos leitores mais atentos, certa confusão sobre o que está ou não em vigor. De certo, o papel da autoridade reguladora, diante de uma nova realidade que se conforma sob seu âmbito de competência, é o de utilizar os meios adequados para ordenar e o exercício de atividades financeiras pelos agentes econômicos. A sucessão de normativos e regulamentos se justificaria, portanto, a partir da necessidade de conformar a regulação aos níveis de desempenho e aprimoramento que os agentes econômicos passam a apresentar após períodos de experimentação. A nova orientação pode se revestir de regras mais restritivas ou mais permissivas do que aquelas até então

\footnotetext{
${ }^{70}$ Preocupações apresentadas pelo presidente da Associação Brasileira dos Dirigentes de Entidades Gestoras e Operadoras de Microcrédito, Crédito Popular Solidário e Entidades Similares no VII Seminário BACEN Microfinanças realizado em Belo Horizonte entre os dias 29 de setembro e $1^{\circ}$ de outubro de 2008.
} 
experimentadas, a depender da visão da autoridade sobre o desempenho desses mesmos agentes e dos objetivos a serem buscados pela regulação ${ }^{71}$.

O próximo capítulo apresenta, a despeito do enfado que possa causar no leitor, pequena parcela do conteúdo desses normativos e regulamentos, e prováveis reflexos sobre uma realidade em mutação, a construção de um setor microfinanceiro apoiado (porém não inteiramente) no Sistema Financeiro Nacional. Não se pretende estabelecer relações de causalidade direta entre regulação e transformação dessa mesma realidade, números reveladores de vitórias ou fracassos de entidades que atuam no setor. De modo claro, percebe-se que entidades detentoras ou apoiadas em outras que possuam poder econômico têm maior facilidade em se tornarem histórias de sucesso. Há exemplos de outras, entretanto, que apesar da falta de recursos e de alguma descrença, atingiram seus objetivos, e ainda que restritas a pequenas comunidades, se tornaram paradigmas para o aprimoramento de políticas públicas no setor.

\footnotetext{
${ }^{71}$ Sobre o tema da capacidade normativa de conjuntura dos principais reguladores do mercado financeiro brasileiro, Conselho Monetário Nacional e Banco Central do Brasil, v. J. P. C. V. Rocha, A capacidade normativa de conjuntura no direito econômico: o déficit democrático da regulação financeira, Tese de Doutorado apresentada à Faculdade de Direito da Universidade de São Paulo, junho de 2004, p. 64 e ss.
} 


\section{CAPÍTULO 2}

\section{A PRESTAÇÃO DE SERVIÇOS MICROFINANCEIROS NO BRASIL}

Os CONCEITOS EXPOSTOS NO CAPítUlo 1 SÃO AGORA REVISTOS DE MODO DINÂMICO, EM FACE DE ALGUM DETALHAMENTO NORMATIVO E DE PESQUiSAS SOBRE AGENTES QUE DISPONIBILIZAM SERVIÇOS MICROFINANCEIROS, EM ESPECIAL MICROCRÉDITO, À POPULAÇÃO DE BAIXA RENDA. NÃO HÁ, NESTA DISSERTAÇÃO, A PRETENSÃO DE ESGOTAR TODO O UNIVERSO DE DADOS DISPONÍVEIS SOBRE ESSES MESMOS AGENTES. A OPÇÃO FEITA PELA PRESENTE ANÁLISE FOI A DE SELECIONAR INFORMAÇÕES PERTINENTES AO ESTUDO DO AMBIENTE NORMATIVO EM QUE SE DESENVOLVEM AS MICROFINANÇAS NO PAÍs.

\subsection{Introdução}

Cada uma das formas jurídicas esboçadas no Capítulo 1 passará por um breve estudo no item infra, e seguem expostas de acordo com seu enquadramento normativo. Posteriormente, no item 2.4, tais informações servirão de subsídio a discussões propostas em face de alguns dados sobre a composição da oferta de serviços microfinanceiros no país.

2.2 Disciplina jurídica da prestação de serviços microfinanceiros

a) Instituições sob regulação e fiscalização no âmbito do Sistema Financeiro Nacional

A Lei n. 4.595/64, em seu artigo 17, define como instituição financeira "as pessoas jurídicas públicas ou privadas que tenham como atividade principal ou acessória a coleta, intermediação ou aplicação de recursos financeiros, em moeda nacional ou estrangeira, e a custódia de valor de propriedade de terceiros".

Para os fins do presente estudo, importa a divisão entre as instituições que perseguem predominantemente o lucro na prestação de serviços microfinanceiros (bancos privados e sociedades de crédito ao microempreendedor), e aquelas instituições financeiras, em regra públicas, de algum modo relacionadas a finalidades de 
desenvolvimento regional (como o Banco do Nordeste e o Banco da Amazônia) ou com suas atividades voltadas precipuamente ao atendimento da população de baixa renda (por ex., o Banco Popular do Brasil).

a.1) Instituições financeiras privadas

Quanto aos bancos privados no Brasil que possuem carteira especializada, observase que, em regra, sua atuação se restringe ao oferecimento de microcrédito (atualmente, em volume de recursos emprestados, destaca-se o programa do Banco Real). Além da possibilidade de prestar serviços microfinanceiros diretamente, há bancos privados, como é o caso do Banco Itaú, que disponibilizam linhas de crédito para organizações microfinanceiras parceiras (OSCIPs), que atuam de forma independente.

No item 2.4 a seguir, a partir de dados divulgados pelo Banco Central do Brasil e por algumas instituições financeiras, procura-se descrever, por primeiro, qual a forma de participação dos bancos privados no mercado microfinanceiro brasileiro: oferta direta de serviços para correntistas por meio de carteira especializada, parceria com organizações não-governamentais ou organizações civis de interesse público, entre outras. Em segundo lugar, os mais recentes números sobre o volume de recursos investido por esses agentes no segmento. É comum apontar-se no panorama das microfinanças no Brasil o paradoxo da existência de vultuosos recursos disponíveis (e não aplicados) vs. uma enorme demanda não atendida ${ }^{72}$.

Quanto à destinação de recursos para o setor, merece destaque no plano legislativo a obrigatoriedade de direcionamento de no mínimo $2 \%$, dos saldos dos depósitos à vista captados pelas instituições financeiras ${ }^{73}$ para operações de microcrédito à população de baixa renda e a microempreendedores, conforme a Lei n. 10.735/03:

\footnotetext{
72 Esse diagnóstico transpareceu de modo explícito durante debates ocorridos no VII Seminário BACEN Microfinanças realizado em Belo Horizonte entre os dias 29 de setembro e $1^{\circ}$ de outubro de 2008. Como exemplo, v. a fala de Cristiano Mross, presidente da Associação Brasileira das Entidades Gestoras e Operadoras de Microcrédito, Crédito Popular Solidário e Similares quanto ao represamento, no Banco Central, de 1,5 bilhões, que poderiam atender ao financiamento de instituições microfinanceiras e à demanda por crédito dos microempreendedores.

${ }^{73}$ Limite fixado pela Resolução do Conselho Monetário Nacional n. 3.422/06.
} 
“Art. 1ํㅡ Os bancos comerciais, os bancos múltiplos com carteira comercial e a Caixa Econômica Federal manterão aplicada em operações de crédito destinadas à população de baixa renda e a microempreendedores parcela dos recursos oriundos dos depósitos a vista por eles captados, observadas as seguintes condições:

I - os tomadores dos recursos deverão ser:

a) pessoas físicas detentoras de depósitos à vista e aplicações financeiras de pequeno valor;

b) microempreendedores que preencham os requisitos estabelecidos para operações de crédito concedidas por entidades especializadas em operações de microcrédito; ou

c) pessoas físicas de baixa renda selecionadas por outros critérios; e

I - as taxas de juros efetivas serão limitadas, vedada a cobrança de quaisquer outras taxas ou despesas, à exceção de taxa de abertura de crédito.”

Tais operações são circundadas por parâmetros financeiros diferenciados, nos termos da minuciosa Resolução do Conselho Monetário Nacional n. 3.422/06, que estabelece diferentes faixas de empréstimos, entre mil e dez mil reais, conforme características do tomador (grosso modo, pessoa física detentora de conta ou depósito, pessoa física empreendedora, pessoa física de baixa renda, pessoa física ou jurídica empreendedora de atividade de pequeno porte, tal como definidos na Resolução), contratados sob taxas de juros efetivas cujo teto não pode ultrapassar $2 \%$ ao mês, ou ainda $4 \%$ ao mês, caso se trate de microcrédito produtivo orientado, circundado pelas regras do Programa Nacional de Microcrédito Produtivo Orientado (Lei n. 11.110/05). Cumpre ainda observar que a Resolução incorpora metodologias de microfinanças não usualmente utilizadas na prática bancária, como o aval solidário: “Constitui-se garantia nas operações de microcrédito qualquer garantia aceita pelas instituições financeiras, inclusive aval solidário em grupo com, no mínimo, três participantes, alienação fiduciária e fiança" $\left(\operatorname{artigo} 3^{\circ}, \S 2^{\circ}\right.$ ).

As instituições financeiras podem atuar em parceria com OSCIPs, SCMs, cooperativas singulares de crédito e agências de fomento que prestem diretamente serviços microfinanceiros (art. $4^{\mathrm{o}}$, I, alíneas $a$ a $d$ ), ou ainda repassando recursos a bancos de desenvolvimento, agências de fomento, bancos cooperativos ou cooperativas centrais de crédito que atuem na intermediação de recursos entre instituições financeiras e instituições de microcrédito produtivo orientado habilitadas perante o Ministério do Trabalho e 
Emprego (art. $4^{\circ}, \S 2^{\circ}$ ). Nos termos da Resolução, os recursos não comprovadamente aplicados em atividades de microcrédito serão compulsoriamente recolhidos ao BCB (art. $5^{\circ}, \S 1^{\circ}$ ), e "O valor da deficiência de aplicações em relação ao exigível, se houver, deverá ser recolhido ao Banco Central do Brasil, na forma por ele estabelecida, em moeda corrente, permanecendo indisponível até a data de verificação do cumprimento da exigibilidade no mês seguinte" (art. $6^{\circ}, \S$ único). O cumprimento da exigibilidade de direicionamento de $2 \%$ dos depósitos à vista pelas instituições financeiras pode ser acompanhado no quadro a seguir:

Em R \$ milhões

\begin{tabular}{lcccc}
\hline & $\mathbf{2 0 0 4}$ & $\mathbf{2 0 0 5}$ & $\mathbf{2 0 0 6}$ & $\mathbf{2 0 0 7}$ \\
\hline Exigibilidades & $1.495 .842,78$ & $2.041 .253,99$ & $2.157 .876,09$ & $2.989 .639,97$ \\
\hline Cumprimento & $798.659,33$ & $1.188 .266,98$ & $1.233 .936,70$ & 1.380 .634 .85 \\
DIM $^{1}$ & $7.561,87$ & $68.855,73$ & $106.024,35$ & $82.112,65$ \\
Microfinanças & $655.987,11$ & $921.101,79$ & $825.584,25$ & $941.305,60$ \\
Microcrédito & $133.734,14$ & $197.383,60$ & $301.050,13$ & $355.043,39$ \\
Consignado $^{2}$ & $1.376,21$ & 925,87 & $1.277,97$ & $2.163,21$ \\
\hline \% cumprimento & $53,39 \%$ & $58,21 \%$ & $57,18 \%$ & $46,18 \%$ \\
\hline
\end{tabular}

${ }^{1}$ Depósito Interfinanceiro de Microcrédito.

${ }^{2} \mathrm{Com}$ recursos das exigibilidades.

Fonte: BCB

Como medidas que buscam integrar as instituições bancárias à prestação de serviços microfinanceiros, podem ainda ser mencionadas a regulamentação pertinente às contas simplificadas ${ }^{74}$ e aos correspondentes bancários ${ }^{75}$, sendo os últimos pessoas jurídicas que, por acordo ou contrato, executam serviços em nome de instituição financeira. Sua existência se justifica pelas dimensões continentais do país e pelos vazios gerados na concentração dos bancos em localidades próximas aos grandes centros. Sua existência remonta ao início da atividade bancária no país ${ }^{76}$, e sua importância tem se acentuado com as políticas para disseminação de serviços financeiros à população de baixa renda. Seu papel se limita, em suma, ao encaminhamento de propostas de abertura de

\footnotetext{
${ }^{74}$ Resoluções do Conselho Monetário Nacional n. 3.104/03 e n. 3.113/03.

${ }^{75}$ Resoluções do Conselho Monetário Nacional n. 3.110/03 e n. 3.156/03.

76 Os correspondentes foram inicialmente regulamentados pela Circular BCB n. 220/73, e após pela Resolução CMN n. 562/79. Desde então a regulamentação tem se aperfeiçoado destacando-se como principais normativos a Resolução CMN n. 2.640/99, aperfeiçoada pela Resolução CMN n. 2.707/00, sucedida pela Resolução CMN n. 2.953/02, até chegarmos à regulamentação atualmente em vigor (v. nota supra).
} 
conta, empréstimos, cartões de crédito, recebimento de benefícios, resgates e pagamento de contas. Apesar das limitações regulamentares, os correspondentes bancários assumiram papel estratégico para viabilizar a prestação de serviços em localidades longínquas ou de difícil acesso. O correspondente utiliza a mão de obra ociosa de sua atividade principal para o atendimento, portanto seus funcionários não são considerados bancários e não são aptos a analisar propostas, que são tão somente encaminhadas às agências bancárias para posterior análise e aprovação. Veja-se, por exemplo, a parceria firmada entre o Banco Bradesco e a Empresa Brasileira de Correios e Telégrafos (ECT). Por meio da marca "Banco Postal" a ECT opera como correspondente bancário do Bradesco, o que vale dizer: o Banco Postal não é instituição bancária nos moldes da Lei n. 4.595/64, pois não realiza intermediação financeira, i. e, não coleta ou empresta valores em seu nome. O correspondente incorre, ainda, nas penalidades previstas na Lei 4.595/64 (multa e detenção), caso pratique, em nome próprio e por sua conta e ordem, operações privativas de instituição financeira (Resolução CMN n. 3.110/03, art. $5^{\circ}$ ).

\section{a.2) Sociedades de Crédito ao Microempreendedor (SCM)}

A concepção de entidades reguladas no âmbito do Sistema Financeiro Nacional em consonância com as preocupações da corrente minimalista (v. Capítulo 1, item 1.1) atendeu à pressões do mercado quanto à maior proteção dos investidores interessados em investir no segmento, partindo-se da premissa de que a regulação e supervisão por órgãos federais são capazes de conferir maior confiabilidade e transparência a essas instituições.

Assim, em relação às entidades não-reguladas no âmbito do Sistema Financeiro Nacional, possuem maiores condições de atingir a auto-sustentabilidade, vez que possuem menores custos financeiros e operacionais em decorrência de não possuírem compromisso com a capacitação técnica e educação financeira de seus clientes.

Em um primeiro momento, foram introduzidas em nosso ordenamento jurídico pela Medida Provisória n. 1.894-23/1999, sucessivamente reeditada até que resultou na Medida Provisória n. 2.082-40/2001, posteriormente convertida na Lei n. 10.194/2001. Sua constituição, organização e funcionamento são disciplinadas pelo Conselho Monetário Nacional, e suas operações são fiscalizadas pelo Banco Central. Regulamenta referida lei a Resolução CMN 2.874/2001, que "dispõe sobre a constituição e funcionamento de SCM", 
aperfeiçoou a regulamentação até então existente para as atividades das sociedades de crédito ao microempreendedor (Resolução n. 2.627/99), conforme mostra o quadro a seguir:

\begin{tabular}{|c|c|}
\hline Resolução n. 2.627 (revogada) & Resolução n. 2.874 \\
\hline $\begin{array}{l}\text { Conservadora, sob o ponto de vista da regulação } \\
\text { prudencial: }\end{array}$ & $\begin{array}{l}\text { Inovações após testadas a forma de atuação e } \\
\text { aderência aos princípios norteadores das SCMs: }\end{array}$ \\
\hline - mínimo de 50\% de ações ordinárias; & \\
\hline - autorização para transformar OSCIP em SCM; & $\begin{array}{l}\text { - OSCIP especializada em microcrédito pode } \\
\text { controlar SCM; }\end{array}$ \\
\hline $\begin{array}{l}\text { - atuação e instalação de postos de atendimento } \\
\text { restrita a região pré-determinada em estatuto; }\end{array}$ & $\begin{array}{l}\text { - revogada, criação dos postos de atendimento } \\
\text { do microcrédito (PAM), fixos ou móveis, a } \\
\text { serem instalados em qualquer localidade; }\end{array}$ \\
\hline $\begin{array}{l}\text { - vedação à transformação em outra instituição } \\
\text { financeira pertencente ao SFN; }\end{array}$ & - revogada; \\
\hline $\begin{array}{l}\text { - vedação à participação no capital de outras } \\
\text { empresas. }\end{array}$ & $\begin{array}{l}\text { - veda a participação apenas no capital de } \\
\text { instituição financeira e entidades autorizadas a } \\
\text { funcionar pelo BCB. }\end{array}$ \\
\hline
\end{tabular}

Fonte: BCB

Podem ser constituídas sob a forma de sociedade anônima com capital fechado (Lei 6.404/76) ou de sociedade limitada (Código Civil). Seu capital social não pode ser inferior a cem mil reais, podendo ser integralizado em espécie, de acordo com as normas gerais que regem as instituições financeiras. Seu objeto social abrange a concessão de empréstimos e prestação de garantias para pessoas físicas e pessoas jurídicas classificadas como microempresas nos termos da legislação e regulamentação em vigor, com a finalidade de viabilizar empreendimentos de pequeno porte de natureza profissional, comercial ou industrial, sendo expressamente proibido o financiamento ao consumo. Tais atividades financeiras podem ser desempenhadas por conta própria ou mediante contrato de prestação de serviços, em nome de outra instituição financeira.

A Lei n. 11.110/05 alargou ainda mais seu objeto, ao permitir que a SCM ofereça outros serviços microfinanceiros além do financiamento a pessoas físicas e microempresas, podendo exercer outras atividades definidas pelo $\mathrm{CMN}$, adquirindo maior desenvoltura para atuar sob as finalidades do PNMPO, (Lei n. 11.110/05, artigo $1^{\circ} \S 6^{\circ}$, III).

A Resolução CMN n. 3.422/06 examinada supra (subitem a.1) regulamenta o financiamento, pelos bancos privados, de sociedades de crédito ao microempreendedor participantes do PNMPO. Deste modo, verifica-se, tanto no plano legislativo quanto no 
regulamentar, a sincronia entre instrumentos jurídicos infraconstitucionais que disciplinam a atividade de agentes econômicos atuantes no setor e os fundamentos e princípios da Ordem Econômica, como a valorização do trabalho humano e a busca do pleno emprego (Constituição Federal de 1988, art. 170, caput e inciso VIII).

Nos termos da Resolução BCB 2.874/01, mediante prévia autorização do BCB, o controle societário de uma SCM pode ser exercido por qualquer pessoa física ou jurídica, inclusive por uma OSCIP, hipótese em que a sociedade controladora deve desenvolver atividades de crédito compatíveis com o objeto social da SCM. O poder público, a quem é vedada a participação direta ou indireta nessas sociedades, não pode exercer quaisquer poderes de gestão ou veto às suas atividades, reforçando a restrição de seu papel à concepção de políticas no nível macro. Cumpre frisar, ainda, que a SCM não pode deter participação no capital de outras sociedades.

A possibilidade de uma OSCIP (por lei restrita à atuação sem fins lucrativos) controlar uma SCM inspira-se na experiência boliviana do Banco Sol, e tem o objetivo de permitir que a controladora tenha meios de diversificar suas atividades junto a nichos mais rentáveis e obter capital para atuar junto às camadas mais carentes da população, de modo a democratizar o lucro do grupo ${ }^{77}$. Mais uma vez, a regulação infralegal das microfinanças declara-se apta a perseguir objetivos de políticas públicas de cunho social arquitetadas pelo poder público, conectando instrumentos e agentes econômicos atuantes no Sistema Financeiro Nacional aos objetivos fundamentais de erradicação da pobreza e construção de uma sociedade livre, justa e solidária (Constituição Federal de 1988, artigo $3^{\circ}$ e incisos c/c artigo 192).

Como forma de possibilitar maior capilaridade na prestação de serviços, a Resolução BCB 2.874/01 permite que a SCM instale Postos de Atendimento de Microcrédito (PAM), fixos ou móveis, permanentes ou temporários, em qualquer localidade, dentro da área de atuação da instituição. Além disso, a regulamentação que possibilita a contratação de correspondentes bancários ${ }^{78}$ também é extensível à SCM.

\footnotetext{
${ }^{77}$ O Banco Sol é um banco privado comercial, especializado em microcrédito para empreendedores formais e informais, com financiamentos médios de US\$ 500, para os quais são aceitas garantias reais, solidárias ou aval, com taxas de juros a valor de mercado e prazos de 1 a 12 meses. Seu controle é detido por uma organização não-governamental de microcrédito.

${ }_{78}$ Resoluções do Conselho Monetário Nacional n. 3.110/03 e n. 3.156/03.
} 
Em 2007, a Lei n. 11.524 ampliou o espectro operacional das SCMs, autorizandoas a financiar empresas de pequeno porte, além das já contempladas pessoas físicas e microempresas. Adicionalmente, a respectiva regulamentação infralegal foi expedida pelo CMN, a Resolução n. 3.567/08.

Quanto à captação de recursos, as SCMs podem se valer das seguintes fontes: financiamento de bancos privados, doações, organismos e instituições nacionais e internacionais de desenvolvimento, orçamentos estaduais e municipais, fundos constitucionais, e outras expressamente autorizadas pelo BCB. Suas obrigações (passivo circulante e exigível a longo prazo) não podem ultrapassar cinco vezes o respectivo patrimônio líquido ajustado. Não há a obrigatoriedade da manutenção de um patrimônio líquido em função do nível de risco de suas operações.

Por fim, integram ainda seu quadro normativo uma Carta-Circular do BCB, a de n. 2.898/00, e sete Circulares BCB, de números 2.964/00, 3.172/02, 3.180/03, 3.182/03, $3.197 / 03,3.197 / 03,3.218 / 04$ e 3.310/06, todas em vigor e aplicáveis às SCMs.

a.3) Instituições financeiras públicas

Em vista da divisão proposta neste trabalho (subitem $a$, supra), os bancos públicos merecem tratamento apartado dos bancos privados pela razão de fundirem objetivos de redução de pobreza e desenvolvimento regional à finalidade lucrativa. Por regra, as instituições bancárias controladas pelo poder público participam da prestação de serviços microfinanceiros por meio da criação de carteiras especializadas.

Menciona-se, como algumas de suas vantagens, a grande capilaridade e capacidade de penetração no mercado, dado ser comum a manutenção de agências em cidades de pequeno porte. Além disso, não enfrentariam restrições quanto à disponibilidade de recursos, pois podem tanto acessar fundos públicos quanto captar recursos no mercado financeiro. Poderiam ainda facilmente adaptar sua política de fixação de taxas de modo compatível à capacidade de pagamento de seu mercado-alvo. Como principal desvantagem a ser apontada quanto aos programas de microcrédito desenvolvidos, a "participação 
relativamente ínfima em seus ativos totais, o que gera problema de governabilidade e sustentabilidade desses programas nas instituições"79.

De toda sorte, o principal programa de microcrédito em curso atualmente no país é o Programa CrediAmigo ${ }^{80}$, do Banco do Nordeste, que conjuga a prestação de serviços microfinanceiros à orientação empresarial para microempreendedores e para população de baixa renda. Seu modelo de atuação pode ser resumido pelos principais pontos:

i) auto-sustentabilidade como princípio básico do programa;

ii) crédito produtivo e orientado em primeiro piso (i. e, prestação de serviços diretamente à população;

iii) técnicas e metodologia específica para microcrédito urbano;

iv) trâmite ágil, adequado ao ciclo dos negócios desenvolvidos por sua clientela; e

v) prazos curtos e de pequeno montante.

Os serviços prestados incluem empréstimos para capital de giro e investimento fixo, 'CrediAmigo Comunidade' (village bank), conta corrente normal e simplificada, seguro de vida, seguro prestamista e orientação empresarial e ambiental. Para a obtenção de pequenos empréstimos, os tomadores devem apresentar documentação reduzida e poucos requisitos, a saber:

i) comprovar identidade e maioridade, apresentar inscrição no Cadastro de Pessoas Físicas (CPF), e comprovante da atual residência;

ii) deter ou iniciar uma atividade comercial; e

iii) reunir um grupo de amigos empreendedores, que morem ou trabalhem próximos e que confiem uns nos outros.

Para alcançar os microempreendedores nas suas comunidades, o BNB constituiu a OSCIP Instituto Nordeste Cidadania ${ }^{81}$ como sua mandatária para a realização de:

\footnotetext{
${ }^{79}$ S. Parente, cit., p. 145.

${ }^{80}$ Recentemente o Banco Interamericano de Desenvolvimento conferiu ao CrediAmigo o prêmio excelência em microfinanças para a América Latina e Caribe. As informações ora transcritas têm como fonte material da Área de Microfinanças e Programas Especiais do BNB.

${ }^{81} \mathrm{O}$ Instituto possui mais de mil colaboradores, entre técnicos, agentes de crédito, assessores administrativos e de recursos humanos, coordenadores.
} 
i) Seleção e contratação de pessoal administrativo e agentes de crédito;

ii) operacionalização de produtos e serviços mediante a atuação de agentes de crédito nas comunidades;

iii) monitoramento do emprego das técnicas e do processo metodológico; e

iv) acompanhamento da evolução dos tomadores de empréstimos, do desenvolvimento de seus pequenos negócios etc.

O BNB, por sua vez, tem as seguintes responsabilidades:

i) estabelecer as estratégias empregadas na prestação de serviços microfinanceiros e nas metas a serem alcançadas pelo programa;

ii) elaborar e manter manuais normativos;

iii) definir produtos e serviços oferecidos;

iv) estabelecer e atualizar as técnicas e processo metodológico; e

v) decisão final quanto à concessão de crédito.

A Área de Microfinanças e Programas Especiais do BNB aponta, como fatores de sucesso do programa, o modelo de atuação em parceria com OSCIPs, a capacitação técnica de seus agentes, o estabelecimento de relações de confiança pelos agentes de crédito nas comunidades, ações antecedentes e subseqüentes à concessão dos empréstimos e parcerias estabelecidas ao longo do processo de maturação do programa ${ }^{82}$. Em face dos resultados obtidos nos últimos anos, o BNB criou uma segunda carteira especializada em microcrédito produtivo orientado, o AgroAmigo, destinado a atender a produtores rurais de pequeno porte da região Nordeste, norte de Minas Gerais e norte do Espírito Santo. Iniciou recentemente sua atuação junto ao público-alvo do Programa Nacional de Agricultura Familiar (Pronaf), sendo que a metodologia empregada é a mesma do CrediAmigo, com as necessárias adaptações ao meio rural.

Segundo pesquisa que investigou a fundo o CrediAmigo, sua metodologia voltada para o microcrédito produtivo orientado, auto-sustentabilidade e impactos econômicos e sociais observados nas comunidades em que está presente,

${ }^{82}$ Desde sua criação, no início dos anos 2000, o CrediAmigo estabeleceu parcerias com o Banco Mundial, CGAP, Acción International, OSCIPs, prefeituras municipais e governo federal. 
“(...) é importante notar que o programa gera lucro de cerca de 50 reais/ano por operação levando em conta todos os custos inclusive o de oportunidade financeiro. Os resultados empíricos situam o CrediAmigo pela combinação dos quesitos tamanho, equidade, eficiência no mapa das principais políticas públicas do país. O aspecto ímpar a ser ressaltado é o da sustentabilidade, tanto do ponto de vista financeiro do programa como nas melhoras acarretadas nas vidas dos clientes tanto do ponto de vista das empresas como das famílias dos microempresários" ${ }^{\text {}}$.

Percebe-se, portanto, o importante peso de iniciativas do poder público em setores que, de início, não se mostram tão atraentes à iniciativa privada. Como será relatado no Capitulo 2, a seguir, o CrediAmigo tornou-se paradigma seguido por instituições bancárias públicas e privadas que passaram a se interessar pelo segmento e dar início à sua carteira de microcrédito inspirando-se na metodologia utilizada pelo BNB. Alguns números sobre o programa serão ainda detalhados no item 2.4 , a seguir.

\section{a.4) Cooperativas de crédito}

Apesar de serem entidades reguladas no âmbito do Sistema Financeiro Nacional como instituições financeiras (Lei 4.595/64, art. 17, transcrito supra, subitem $a$ ) as cooperativas de crédito não possuem finalidade lucrativa. Foram reconhecidas durante os debates para concepção do marco regulatório como a forma jurídica mais apta a viabilizar a atividade de instituições microfinanceiras de caráter local. O governo federal, e em especial Ministério do Trabalho e Emprego, Secretaria Nacional de Economia Solidária e $\mathrm{BCB}$ recentemente têm promovido iniciativas para a valorização do cooperativismo de crédito no país, sob a justificativa de que:

"O setor cooperativista é de singular importância para a sociedade, na medida em que promove a aplicação de recursos privados e assume os correspondentes riscos em favor da comunidade onde se desenvolve. Por representar iniciativas dos próprios cidadãos, contribui de forma relevante para o desenvolvimento local sustentável, especialmente nos aspectos de formação de poupança e de financiamento de

\footnotetext{
${ }^{83}$ Microcrédito, o Mistério Nordestino e o Grammen Brasileiro, coordenação de Marcelo Côrtes Neri, Rio de Janeiro: FGV/IBRE, CPS, 2008, p. 93, disponível em www.fgv.br .
} 
iniciativas empresariais que trazem benefícios evidentes em termos de geração de empregos e de distribuição de renda., ${ }^{, 84}$

A evolução regulamentar das cooperativas inicia-se em 1965 e segue até a atualidade $^{85}$. Para os limites do presente trabalho, cumpre apenas revisar o período mais recente da produção normativa sobre o cooperativismo, a partir das discussões para o marco regulatório das microfinanças, no final da década de 90 (v. item 1.3, c, supra), e em especial sua participação no âmbito do Programa Nacional de Microcrédito Produtivo Orientado, conforme relata o Capítulo 3, a seguir.

A partir de 1992 observou-se o início de significativas mudanças legislativas, na medida em que passaram a serem exigidos das cooperativas praticamente os mesmos fundamentos e princípios aplicáveis às instituições financeiras, ainda que sua representatividade no Sistema Financeiro Nacional fosse significativamente inferior em termos de impacto, ativos financeiros e risco sistêmico. O objetivo do endurecimento por parte da autoridade reguladora, em suma, era o de evitar o oportunismo de agentes pouco idôneos e desconectados dos princípios cooperativistas e da pretensão associativista. $\mathrm{O}$ período anterior havia sido marcado pelo uso irresponsável do modelo e por incidentes como a quebra do Banco Nacional de Crédito Cooperativo (BNCC) e a conseqüente crise de confiança no segmento. Naquele ano, foram tomadas medidas como a Resolução CMN n. 1.914, que proibiu a constituição de novas cooperativas abertas ao público em geral (as cooperativas Luzzatti).

As maiores restrições não foram desacompanhadas de protestos do setor, e seguiram-se respostas regulamentares para adequar o ambiente normativo às necessidades de coordenação e canalização de recursos originários do cooperativismo em geral. Seguiuse então a Resolução CMN n. 2.193/95, imediatamente aproveitada por dois dos principais sistemas cooperativistas, Sicredi e Sicoob, que criaram respectivamente o Banco Cooperativo Sicredi (Bansicredi) e o Banco Cooperativo do Brasil (Bancoob), que operavam entretanto sob severas restrições se comparados aos bancos comerciais. Os

\footnotetext{
${ }^{84}$ M. M. Soares \& A. D. Melo Sobrinho Microfinanças: O papel do Banco Central do Brasil e a importância do cooperativismo de crédito, cit., p. 69.

${ }^{85}$ Há uma lista não desprezível de Resoluções do Conselho Monetário Nacional a respeito. A suma de suas diretrizes, principais objetivos e debates que as envolveram pode ser consultada em M. M. Soares \& A. D. Melo Sobrinho Microfinanças: O papel do Banco Central do Brasil e a importância do cooperativismo de crédito, cit., p. 71 e ss.
} 
bancos cooperativos passaram então por anos de amadurecimento e experimentação, acompanhados pela edição de leis e sucessivos normativos pelo Conselho Monetário Nacional e Banco Central do Brasil, por exemplo, Lei n. 9.848/99 e Resolução CMN n. 3.188/04, sobre operação de crédito rural, Resolução CMN n. 2.608/99, referente à redução dos riscos de crédito e aumento da capacidade das cooperativas, Resolução CMN n. 2.771/00, a respeito do reforço do papel das cooperativas centrais e adaptação às regras da Basiléia, e Resolução CMN n. 2.788/00, que trata da equiparação dos bancos cooperativos aos bancos comerciais.

Finalmente, uma das respostas aos entraves relativos à carência e o alto custo de empréstimos a micro e pequenos empreendedores foi a Resolução CMN n. 3.058/02, que possibilitou a criação de cooperativas de micro e pequenos empresários e microempreendedores do ramo industrial, comercial ou de serviços, inclusive atividades da área rural, cuja receita bruta anual, no momento da associação, fosse igual ou inferior ao limite fixado na legislação vigente para as pequenas empresas. O novo regramento inovou ao deixar de exigir que as cooperativas fossem segmentadas por ramos especializados de atividade. Além disso, foram equiparados os empreendedores urbanos aos rurais, possibilitando a constituição de uma única cooperativa integrada por empresários urbanos e produtores rurais, de modo a conferir maior estabilidade à cooperativa como um todo, contrabalanceando os lucros e perdas sazonais de cada um dos segmentos.

Destacam-se ainda, no período, normativos sobre questões estruturais básicas do sistema cooperativo: i) a Resolução CMN n. 3.106/03 relativa à "criação de cooperativas de livre admissão de associados, porém com grande dose de aprimoramento dos dispositivos regulamentares, desde ampliação, fortalecimento e maiores exigências das Centrais de Crédito até a obrigatoriedade da apresentação de projeto para as novas cooperativas ou para a transformação das existentes"; e ii) Resolução CMN n. 3.140/03, que faculta a existência de cooperativas de crédito centradas na vinculação a uma entidade de classe específica, cuja peculiaridade reside no menor risco em relação às cooperativas de livre associação e maior escala potencial quando comparadas às cooperativas tradicionais, segmentadas por categoria profissional ou por vínculo empregatício.

Quanto aos desafios recentes gerados pelo crescimento do setor e da demanda por crédito, a Resolução CMN n. 3.442/2007 ampliou a capacidade operacional das 
cooperativas de livre admissão, por meio do aumento do seu limite populacional, acompanhado das devidas exigências de ajuste quanto ao seu capital e patrimônio, condizentes com sua ampliação e impacto junto às comunidades em que atuam. Segundo o $\mathrm{BCB}$, o esforço regulatório tendente a realizar ajustes na regulamentação de modo a tornála mais adequada à realidade do setor passa pela sua aproximação aos padrões internacionais definidos pelo Comitê da Basiléia ${ }^{86}$.

No campo das propostas legislativas, o governo federal parece avançar nas negociações legislativas tendentes à aprovação de projetos de lei que versam sobre a chamada Lei das Sociedades Cooperativas, definição do ato cooperativo e tributação dos principais setores cooperativos ${ }^{87}$.

Atualmente, com base no quadro normativo em vigor, as cooperativas podem ser classificadas em três perfis:

i) vertical, cuja característica é a estrutura piramidal, composta por base de cooperativas singulares, cooperativas centrais na faixa intermediária e confederações no ápice, busca centralização e ganhos de escala;

ii) horizontal, composto de redes de cooperativas solidárias, urbanas ou rurais, organizadas sob estrutura radial, com diversas cooperativas singulares vinculadas a uma central ou associação representativa; e

iii) independente, formado por cooperativas que possuem apenas estrutura de primeiro nível.

Quanto aos programas federais de estímulo ao setor, cumpre mencionar rapidamente o PoupaCred, cuja finalidade é capitalizar as cooperativas de crédito e ampliar o valor das quotas-partes dos empreendedores nas suas cooperativas, possibilitando que o valor do crédito recebido seja elevado; e o Programa Nacional de Agricultura Familiar

\footnotetext{
${ }^{86}$ M. M. Soares \& A. D. Melo Sobrinho Microfinanças: O papel do Banco Central do Brasil e a importância do cooperativismo de crédito, cit., p. 93.

${ }^{87}$ No que tange à modernização da legislação cooperativista, há um conjunto de medidas recentemente tomadas pelo governo federal: esforços para a aprovação, na Câmara dos Deputados, do Projeto de Lei Complementar 117/04, que regulamenta o cooperativismo de crédito; elaboração de proposta para a Lei de Sociedades Cooperativas (a chamada 'Lei Geral'); encaminhamento ao Congresso Nacional do Projeto de Lei Complementar 386, que define o ato cooperativo e trata do seu adequado tratamento tributário, e do Projeto de Lei Complementar 3723/08, que trata da tributação das sociedades cooperativas em geral no âmbito federal.
} 
(Pronaf), operado por bancos públicos federais e cooperativas de crédito, que tem por fim beneficiar a população rural ligada à agricultura familiar, por meio da busca da equalização de taxas de juros e cobertura de parte dos custos bancários. Por fim, ressalte-se que o governo federal divulga como uma de suas metas para o setor microfinanceiro a ampliação do número e da participação das cooperativas de crédito no Sistema Financeiro Nacional ${ }^{88}$.

b) Instituições não reguladas ou não supervisionadas no âmbito do Sistema Financeiro Nacional

Tal como relatado supra, a construção normativa do arcabouço regulatório das microfinanças no país não derivou da adoção de um modelo específico (item 1.3, $a$, supra). Nesse cenário, convivem com as variadas formas de instituições financeiras descritas supra (bancos comerciais, bancos público, SCMs e cooperativas de crédito) outras entidades, não reguladas e não supervisionadas pelo $\mathrm{CMN}$ e pelo BCB. São, especificamente, organizações não-governamentais, organizações da sociedade civil de interesse público, e fundos públicos estaduais e municipais, os chamados "Bancos do Povo". Segue-se uma descrição breve de cada uma dessas formas:

b.1) Organizações Não-Governamentais e Organizações da Sociedade Civil de Interesse Público

As organizações não-governamentais especializadas em microfinanças, pioneiras no desenvolvimento de técnicas e métodos de atuação junto à população carente, têm como vantagens o longo período de experimentação a que se submeteram desde o início da concepção de instrumentos microfinanceiros para o segmento microempresarial. Por outro lado, por ocasião dos estudos para o marco regulatório das microfinanças no país, apontava-se como uma de suas principais deficiências a incapacidade de gestão operacional e financeira para trabalhar em escala massificada, bem como a dificuldade de acesso a capitais ${ }^{89}$. Por regra, atingem pequenas e poucas localidades, de modo a impossibilitar que suas atividades tenham impacto e visibilidade em escala nacional. Ressalte-se, por fim, que as organizações não-governamentais são sujeitas a restrições

\footnotetext{
${ }^{88}$ Tal como afirmado em palestra proferida por Gilson Abreu Bittencourt, Secretário-Adjunto de Política Econômica do Ministério da Fazenda, em 30 de setembro de 2008, no VII Seminário BACEN Microfinanças realizado em Belo Horizonte.

${ }^{89}$ S. Parente, cit., p. 143.
} 
quanto aos juros praticados em suas operações, i. e, limitados ao teto de $12 \%$ ao ano, nos termos da Lei de Usura.

A partir de 1999, com o preenchimento dos requisitos dispostos na Lei n. 9.790 quanto à adequação de seu objeto social e normas estatutárias, as organizações nãogovernamentais, pessoas jurídicas de direito privado sem fins lucrativos, puderam optar pela sua qualificação como Organizações Civis de Interesse Público (OSCIP).

Assim, de acordo com sua disciplina normativa, "considera-se sem fins lucrativos a pessoa jurídica de direito privado que não distribui, entre os seus sócios ou associados, conselheiros, diretores, empregados ou doadores, eventuais excedentes operacionais, brutos ou líquidos, dividendos, bonificações participações ou parcelas do seu patrimônio auferidos durante o exercício de suas atividades, e que os aplica integralmente na consecução do respectivo objeto social." (artigo $1^{\circ}, \S 1^{\circ}$ ). Seu objeto social, no que diz respeito às atividades que interessam ao presente estudo, deve contemplar finalidades de cunho social como a "promoção do desenvolvimento econômico e social e combate à pobreza", e "experimentação, não lucrativa, de novos modelos sócio-produtivos e de sistemas alternativos de produção, comércio, emprego e crédito" (Lei n. 9.790, artigo $3^{\circ}$, VIII e IX).

Para os fins do presente estudo, destaca-se, ainda, a proibição de qualificação como OSCIP, dentre outras, das sociedades comerciais, cooperativas e organizações creditícias que tenham quaisquer tipos de vinculação com o Sistema Financeiro Nacional a que se refere o artigo 192 da Constituição Federal (artigo $2^{\circ}$ e incisos). Além disso, deve haver a previsão expressa em seus estatutos da observância dos princípios da legalidade, impessoalidade, moralidade, publicidade, economicidade e da eficiência (artigo $4^{\circ}$, I), norteadores da administração pública direta e indireta (artigo 37, caput, da Constituição Federal de 1988).

Não sujeitas à supervisão do $\mathrm{BCB}$, as organizações não-governamentais que desejarem obter qualificação de OSCIP devem formular requerimento ao Ministério da Justiça (Lei n. 9.790/99, artigo $5^{\circ}$ ). Tal qualificação pode ser perdida a pedido da própria organização ou mediante decisão proferida em processo administrativo ou judicial, de 
iniciativa popular ou do Ministério Público, assegurados o contraditório e a ampla defesa (Lei n. 9.790/99, artigo $7^{\circ}$ ).

Por fim, não são sujeitas a restrições quanto aos juros praticados, i. e, sobre as mesmas não incidem os termos da Lei de Usura, podendo alcançar remuneração adequada às suas atividades, assegurando sua auto-sustentabilidade. Como frisado anteriormente, esta foi uma importante medida dos trabalhos de concepção do marco regulatório para a alavancagem do setor, na medida em que permite às instituições microfinanceiras operarem com taxas de juros livres e condizentes com as praticadas no mercado, e não com restrições quanto ao seu teto máximo.

Há, ainda, uma específica forma que começa a se delinear no universo das pessoas jurídicas de direito privado sem fins lucrativos (ONGs e OSCIPs): os chamados "Bancos Comunitários". São assim chamados por serem utilizados como apoio a comunidades carentes, e podem ser definidos como "conjunto de serviços financeiros de caráter solidário, em rede, de natureza associativa e comunitária, voltado para o desenvolvimento e reorganização da economia local, tendo por base os princípios da economia solidária" ${ }^{90}$, sendo fundamentais três elementos da sua definição, a saber: i) a noção de território, ou o círculo de relações comunitárias que articulam ii) os serviços financeiros de natureza associativa e iii) a rede de parceiros locais. Assim, ao revés da comunidade adquirir serviços diretamente de correspondentes bancários, o faz por meio dos parceiros locais, lideres comunitários ou organizações não-governamentais envolvidas com a dinâmica da comunidade mesma. Os parceiros locais, prestadores de serviços financeiros, cuja função seria precipuamente substituir os custos iniciais da construção física de um banco comunitário são, por sua vez, associados ao Banco Popular do Brasil (braço microfinanceiro do Banco do Brasil) para utilização de sua rede de correspondentes.

A vantagem apontada no modelo seria justamente aquela atinente à reorganização da economia local, na medida em que os serviços são geridos com participação dos membros da comunidade, promovendo sua integração com ganhos de auto-estima e

\footnotetext{
${ }^{90}$ Conceito apresentado por Antônio Haroldo Pinheiro Mendonça, Coordenador Geral de Comércio e Crédito da Secretaria Nacional de Economia Solidária, durante a palestra "Bancos Comunitários e Fundos Solidários", proferida no VII Seminário BACEN Microfinanças realizado em Belo Horizonte, em outubro de 2008.
} 
reconhecimento da importância da construção conjunta das finanças locais. O banco comunitário oferece serviços financeiros como depósitos e saques, cartão de crédito popular, pagamento de benefícios e salários, recebimento de títulos e contas, e ainda promove a circulação das chamadas 'moedas sociais', definidas como "sistema de pagamentos criado e administrado em sistema fechado pelos seus próprios usuários, por meio de organizações sem fins lucrativos, nas quais é valorizado o capital humano aplicado no processo de produção, circulação e distribuição de bens e serviços produzidos na economia real"'91.

O governo federal, por meio da Secretaria Nacional de Economia Solidária, tem como meta expandir os 33 bancos comunitários existentes para 183, até o ano de 2010. Como afirmado por representantes do Ministério do Trabalho e Emprego, a inspiração de suas técnicas e metodologia é o "Banco Palmas" "92_ ${ }^{93}$, constituído a partir da Associação de Moradores do Conjunto da Palmeira, localizado na periferia de Fortaleza, principal banco comunitário hoje em funcionamento". O "Banco Palmas" agrega aos serviços microfinanceiros prestados outras funcionalidades que extrapolam os primeiros, como a promoção de atividades educacionais e de saúde preventiva, oficinas para capacitação de jovens e adultos, entre outras.

Ressalte-se, por fim, que nos termos da legislação supramencionada (item 1.3, $a$ e b), pode uma OSCIP, mediante prévia autorização do $\mathrm{BCB}$, deter o controle societário de uma SCM, esta sim entidade com fins lucrativos, que portanto distribui lucros aos seus sócios, e é regulada no âmbito do Sistema Financeiro Nacional. Uma e outra continuam a

\footnotetext{
${ }^{91}$ Merece ainda destaque o fato de que, segundo estudos desenvolvidos no âmbito do BCB, são instrumentos compatíveis com a política monetária sob competência dos bancos centrais e podem ser usadas como instrumento de política pública de inclusão social, pois seu uso cresce de modo anticíclico à atividade econômica desempenhada sob a moeda oficial. Conceitos e funcionalidades atinentes às moedas sociais foram apresentados por Marusa Vasconcelos Freire, Coordenadora-Geral do Centro de Estudos Jurídicos da Procuradoria-Geral do BCB, na palestra "Moedas Sociais - o que são, como funcionam e por que podem ser consideradas instrumentos de desenvolvimento local" VII Seminário BACEN Microfinanças realizado em Belo Horizonte, outubro de 2008.

${ }_{92}$ www.bancopalmas.org.br

${ }^{93}$ Afirmação feita por Antônio Haroldo Pinheiro Mendonça, Coordenador Geral de Comércio e Crédito da Secretaria Nacional de Economia Solidária durante a palestra "Bancos Comunitários e Fundos Solidários", proferida no VII Seminário BACEN Microfinanças realizado em Belo Horizonte, em outubro de 2008.

${ }_{94}$ Inicialmente as atividades do "Banco Palmas" foram objeto de investigação em ação judicial promovida pelo Ministério Público e BCB contra a Associação de Moradores do Conjunto da Palmeira, em razão das atividades de intermediação financeira desempenhadas à revelia da supervisão e fiscalização cabível para entes atuantes no âmbito do Sistema Financeiro Nacional, bem como a circulação de moeda paralela, a moeda social "Palma". Mais tarde concluiu-se pelo nulo impacto da iniciativa no âmbito regional e nacional, bem como o seu valor para a comunidade.
} 
atuar como pessoas jurídicas distintas e não perdem com isso suas características (natureza, objeto, permissões e restrições) originalmente conferidas pelas respectivas leis, e continuam sob a regulação e supervisão de órgãos diferentes. Ocorre apenas, como já frisado, que os lucros da SCM podem subsidiar atividades desenvolvidas pela OSCIP junto a comunidades carentes, sendo esta mais uma opção conferida pela legislação para o seu financiamento. Entretanto, segundo o BCB, até meados de 2008 nenhuma OSCIP havia ingressado mencionado pedido de autorização. Como razões para o desinteresse, estudo realizado por representantes do BCB dá destaque "para o baixo nível de profissionalização dos responsáveis pela gestão das OSCIP e para o temor da supervisão e dos custos de observância"95.

O Capítulo 1, item 1.4, apresentou queixas de representantes de OSCIPs quanto às dificuldades em obter financiamento para suas entidades e quanto à obscuridade do marco regulatório. Essas mesmas queixas podem ser ora contrapostas ao estudo imediatamente supra citado, segundo o qual, quanto à inexistência de pedidos de autorização de OSCIPs para o controle de SCMs, "nem sempre a boa intenção normativa obtém a resposta esperada"96. Há que se ponderar, entretanto, o passado recente de incessante sucessão de normas e a vigência de extensa lista de regulamentos e circulares mencionada poucas páginas atrás (item 2.2, a.2), cuja minúcia desafia a atenção e a memória (e quem sabe, também, a paciência) dos leitores mais atentos.

\section{b.2) Bancos do Povo}

São programas concebidos no âmbito de administrações estaduais ou municipais. São, portanto, geridos por autarquias, departamentos ou outras formas previstas em lei, e por vezes atuam em parceria com entidades da sociedade civil e organismos internacionais. São sujeitos à Lei de Usura (juros máximos de 12\% a.a.), e freqüentemente se valem de linhas subsidiadas para a concessão de microcrédito, o que é muito criticado pela literatura em geral ${ }^{97}$, tanto por conta das distorções geradas no mercado e barreiras criadas à entrada de novos entrantes, desestimulados a competir em um cenário de taxas fixadas em nível inferior aos seus custos, quanto do ponto de vista institucional, em razão da

\footnotetext{
${ }^{95}$ M. M. Soares \& A. D. Melo Sobrinho Microfinanças: O papel do Banco Central do Brasil e a importância do cooperativismo de crédito, cit., p. 139.

${ }^{96}$ Idem.

${ }^{97}$ A. Kumar, Access to financial services in Brazil-Directions in Development, cit.
} 
descontinuidade administrativa ínsita à sucessão de mandatos eletivos, e o corrente desprezo às políticas públicas capitaneadas por governantes anteriores. Igualmente, do ponto de vista das políticas públicas de microcrédito, há prejuízos quanto ao aspecto educacional e de aprendizado dos tomadores de recursos, que acabam 'viciados' em ambientes em que não necessariamente precisam envidar esforços para alcançar níveis de produtividade e eficiência que tornem sua atividade empreendedora viável e independente. Assim, nem todos os chamados 'bancos do povo' utilizam tecnologias e metodologias microfinanceiras:

"Exemplo desse último comportamento é o Banco do Povo Paulista, que cobra juros de $1 \%$ ao mês. Com isso, segundo o professor Fernando Nogueira da Costa, do Instituto de Economia da Unicamp, o governo de São Paulo está fornecendo dinheiro a fundo perdido - ou seja, dinheiro do orçamento do Estado.

Argumentando com a experiência internacional, que desaconselha operar com taxas inferiores às de mercado, pois isso elimina a possibilidade de a agência alcançar sua autonomia política e auto-sustentabilidade econômica, o professor qualifica essa orientação de 'populismo financeiro', e alerta: 'Essa abordagem sectarista de crédito subsidiado a fundo perdido trabalharia contra o microcrédito auto-sustentado durante vários governos" ${ }^{\prime 98}$.

2.3 Quadro geral da demanda por serviços microfinanceiros

Segundo informações da Pesquisa Nacional por Amostras de Domicílio de 2007, (PNAD 2007), realizada pelo IBGE, as pessoas com 10 ou mais anos de idade, ocupadas em atividades laborativas, estariam distribuídas de acordo com as seguintes faixas de rendimento, em salários mínimos:

\footnotetext{
${ }^{98}$ S. Parente, Microfinanças, cit., p. 101.
} 


\section{$\%$}

40

35

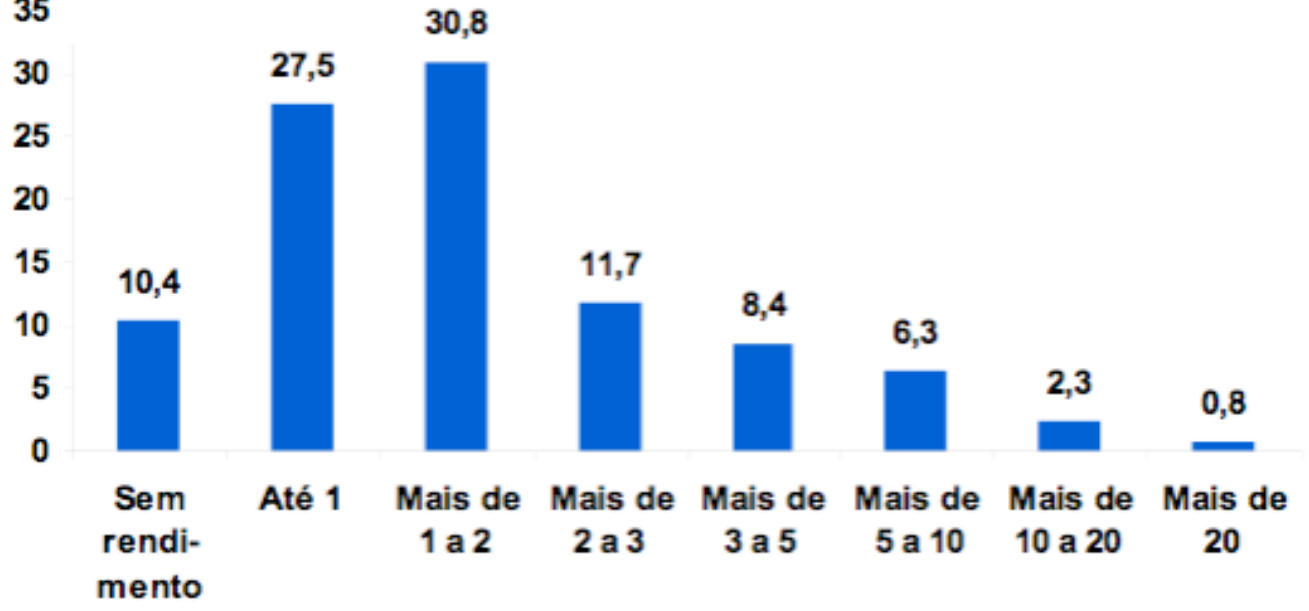

Fonte: PNAD 2007, IBGE.

O público-alvo da prestação de serviços microfinanceiros, segundo estudos do $\mathrm{BCB}$, estaria situado na faixa " $\mathrm{A}$ " entre 0 (sem rendimento ${ }^{99}$ ) e mais de 2 a 3 salários mínimos, (inclusive esta). Por fim, as cooperativas de crédito teriam espaço de atuação na faixa "B" compreendida entre mais 2 e 3 salários mínimos (inclusive esta) e mais de 5 a 10 salários mínimos (inclusive esta). As instituições financeiras bancárias, por sua vez, atuariam na faixa “C”" a partir de mais de 5 a 10 salários mínimos (inclusive esta) ${ }^{100}$.

O BCB calcula que, das cerca de 87 milhões de pessoas que integram a faixa "A", $80 \%$, i.e, cerca de 70 milhões, estariam na faixa de renda compatível com a utilização de serviços microfinanceiros. $\mathrm{O}$ estudo estima ainda que dentre esses 70 milhões de pessoas, metade desse contingente teria interesse em obter crédito, o que significa 35 milhões de efetivos demandantes por microfinanças. O número de operações realizadas em 2007 sugere que cerca de 21 milhões dos efetivos demandantes tiveram acesso a serviços, ou, dito de outro modo, $60 \%$ da demanda estaria hoje atendida.

\footnotetext{
${ }^{99}$ Dentre as pessoas classificadas como "sem rendimento", i. e, os 10,4\% apontados no gráfico, estariam incluídas aquelas que recebem apenas benefícios do Estado.

${ }^{100}$ Fonte: BCB.
} 
Tabela 1

\begin{tabular}{lc}
\hline \multicolumn{1}{c}{ Contratos } & dez/2007 \\
\hline Operações microfinanças - recursos direcionados & 6.154 .431 \\
Empréstimo consignado - recursos livres $^{2}$ & 12.572 .283 \\
Empréstimo consignado - recursos direcionados $^{2}$ & 25.209 \\
Cooperados $^{4}$ & 1.388 .780 \\
Microcrédito & 1.063 .303 \\
\hline TOTAL & 21.204 .086 \\
\hline${ }^{1}$ Contratos vigentes ao final do ano. & \\
${ }^{2}$ Público microfinanceiro (40,2\% de todo público tomador), calculado sobre a soma dos contratos até o final \\
${ }^{3}$ a ano. \\
${ }^{3}$ A faixa entre 2 e 3 salários mínimo abriga tanto cooperados quanto a faixa de rendimento mais alto do \\
público potencialmente consumidor de serviços microfinanceiros, i. e, 39,68\% desse público. \\
${ }^{4}$ Número correspondente à demanda atendida, ou 60\% dos 35 milhões de efetivos demandantes. \\
Fonte: BCB (adaptado).
\end{tabular}

A demanda específica por microcrédito, por sua vez, de acordo com a pesquisa Ecinf 2003 do IBGE (v. Capítulo 1, item 1.2), estimou dezesseis pequenas unidades produtivas possíveis demandantes de microcrédito, dentre as quais treze milhões seriam formadas por trabalhadores por conta própria. O BCB estima que metade desse contingente, i. e, sete milhões de microempresas, seriam potenciais clientes de serviços microfinanceiros.

\subsection{Oferta de serviços microfinanceiros}

De acordo com o BCB, em dezembro de 2007 existiam 228 instituições que atendiam a cerca de um milhão de cliente ativos. Com base em estimativas a partir dos dados extraídos da Ecinf 2003, apenas 16\% da demanda por microcrédito estaria atendida, levando-se em conta o universo de sete milhões de microempreendedores potenciais clientes de serviços microfinanceiros.

A oferta de microcrédito no país, apesar de não corresponder totalmente à demanda, é composta por variada gama de agentes e programas. Seguem números de 2007: 
Tabela 2

\begin{tabular}{lcccc}
\hline \multicolumn{1}{c}{ Agentes ou Programas } & Quantidade & Clientes & $\begin{array}{c}\text { Valor médio do } \\
\text { empréstimo (R\$) }\end{array}$ & $\begin{array}{c}\text { Valor emprestado } \\
\text { (R\$ milhões) }\end{array}$ \\
\hline Bancos privados & 4 & 65.587 & $1.680,00$ & 78,70 \\
SCMs & 53 & 20.145 & $2.531,92$ & 51,01 \\
ONGs, OSCIPs e fundos públicos & 143 & 94.856 & 724,47 & 68,27 \\
CrediAmigo & 1 & 299.975 & 782,07 & 234,60 \\
Cooperativas microempresários & 27 & 64.637 & $3.921,06$ & 253,45 \\
Recursos direcionados ${ }^{1}$ & - & 518.182 & 970,74 & 503,02 \\
\hline TOTAL & 228 & 1.063 .383 & $1.768,38$ & $1.189,49$ \\
\hline
\end{tabular}

${ }^{1}$ Aplicação de $2 \%$ dos depósitos à vista captados por várias instituições financeiras, exceto cooperativas de crédito, nos termos da Lei n. 10.735/03, calculada pela soma dos contratos até dezembro.

Fonte: BCB (adaptado).

Para fins de exposição e compreensão sobre os dados selecionados por diferentes agentes e programas, o presente capítulo está dividido em subitens que os contemplam, e trazem algumas informações sobre os serviços que ofertam ao público, bem como sobre as diferentes modalidades de parcerias estabelecidas para viabilizar a prestação dos mesmos.

a) Bancos privados e sociedades de crédito ao microempreendedor

Usualmente, as pesquisas no setor microfinanceiro indicam que seriam quatro os bancos privados brasileiros que operam no segmento de microcrédito: Real, Unibanco, Santander e Itaú. A partir do quadro a seguir, sobre suas respectivas carteiras de microcrédito no ano de 2007, serão especificadas algumas particularidades da atuação de cada uma dessas instituições: 
Tabela 3

\begin{tabular}{|c|c|c|c|c|}
\hline Banco & Forma de operar & Características & $\begin{array}{l}\text { Saldo da carteira } \\
\text { (R\$ milhões) }\end{array}$ & $\begin{array}{c}\text { Clientes ativos em } \\
\text { dez/2007 }\end{array}$ \\
\hline $\begin{array}{c}\text { ABN/Amro } \\
\text { parceria com } \\
\text { Acción } \\
\text { International }\end{array}$ & $\begin{array}{l}\text { Convênio com a } \\
\text { OSCIP Real } \\
\text { Microcrédito }\end{array}$ & $\begin{array}{c}\text { faixa: entre } \mathrm{R} \$ 500 \\
\text { a R } \$ 10 \text { mil; juros } \\
\text { de } 3,5 \% \text { a.m.; } \\
\text { TAC } 5 \%\end{array}$ & 53,4 & 53.421 \\
\hline Santander Banespa & $\begin{array}{l}\text { oferta direta a } \\
\text { correntistas via } \\
\text { convênios com } \\
\text { ONG e OSCIP }\end{array}$ & $\begin{array}{l}\text { Programa de } \\
\text { Microcrédito- entre } \\
\text { R\$100 a R } \$ 1 \text { mil; } \\
\text { juros } 2 \% \text { a.m. }\end{array}$ & 13,7 & 7.062 \\
\hline Unibanco/Fininvest & $\begin{array}{c}\text { controle de SCM } \\
\text { (Microinvest) }\end{array}$ & $\begin{array}{l}\text { predomínio do } \\
\text { microcrédito } \\
\text { individual urbano }\end{array}$ & 10,3 & 4.330 \\
\hline Banco Itaú & $\begin{array}{l}\text { convênios com } \\
\text { OSCIPs - compra } \\
\text { de carteira }\end{array}$ & 4 OSCIPs parceiras & 1,3 & $774^{1}$ \\
\hline Total & & & 78,7 & 65.587 \\
\hline
\end{tabular}

Dentre os agentes da iniciativa privada, em primeiro lugar na tabela destaca-se o Banco Real, com seu programa Real Microcrédito, em parceria com a Acción International, que possui larga experiência, em diversos países, na prestação de serviços microfinanceiros. A metodologia utilizada é a do microcrédito produtivo orientado, que obriga a instituição financeira a prestar consultoria ao cliente, bem como acompanhar o destino dos recursos tomados. A tarefa não é desempenhada diretamente pelo banco, mas por agentes de crédito de OSCIP conveniada, a Real Microcrédito. Segundo dados da própria instituição, sua carteira atingiu recentemente, em 2008, a marca de 75 mil clientes. Em abril de 2008, seria a principal dentre os bancos privados, perdendo apenas para os valores investidos pelo BNB e pelo BNDES no segmento:

Tabela 4

\begin{tabular}{lcc}
\hline \multicolumn{1}{c}{ Instituição } & Carteira R\$ milhões & Participação \% \\
\hline BNB & 238.900 & 51,6 \\
BNDES & 67.851 & 14,7 \\
Banco Real & 64.071 & 13,8 \\
Outros & 91.892 & 19,9 \\
\hline Total & 462.714 & 100 \\
\hline
\end{tabular}

Fonte: BNDES e BCB, dados de abril de 2008.

Em segundo lugar na lista dos bancos privados que possuem carteira especializada em microcrédito está o Santander Banespa, que a operacionaliza por meio de ONGs e 
OSCIPs. Destaca-se o convênio com a OSCIP de parceria público privada Crédito Popular Solidário - Programa São Paulo Confia (v. item infra).

Em terceiro lugar no atendimento à demanda de microcrédito encontra-se o Unibanco, que atua de forma articulada à SCM Microinvest, cujo quadro acionário é detido pelo próprio Unibanco ( $82 \%$ das ações) e pela International Finance Corporation (18\%), braço privado do grupo Banco Mundial. Também utiliza a metodologia do microcrédito produtivo orientado e concede empréstimos para microempreendedores com ao menos 1 ano de atividade, formais ou informais, para a ampliação de seus negócios, reformas, compras de matéria-prima. Dentre as 53 SCMs atuantes no país, a Microinvest é a maior em número de clientes e volume de recursos emprestados. Por ser controlada por um grande banco privado, pertencendo ao mesmo grupo empresarial, este estudo a considerará à parte daquelas SCMs que porventura atuem sob o controle de OSCIPs, alinhadas a finalidades de cunho social.

As SCMs hoje em atividade no país distribuem-se regionalmente de acordo com a proporção: Sudeste $69,8 \%$, Sul 17\%, Norte 5,7\%, Nordeste 5,7\% e Centro Oeste 1,9\%. Dentre as SCMs constituídas até meados de 2008, 60\% eram de propriedade de novos investidores, sendo as demais detidas por empreendedores especializados em empresas de fomento mercantil (factoring) "que, sob o manto da estrutura formal, buscam, na maioria dos casos, melhorar sua imagem junto ao público, como forma de angariar mais clientes" ${ }^{\prime 101}$.

Por fim, o Itaú, por meio da Fundação Itaú Social, busca ampliar sua participação no segmento por meio de articulação de uma rede institucional tendente a potencializar a aplicação de recursos em iniciativas de microcrédito, o que almeja alcançar por meio do desenvolvimento de instituições já existentes e o apoio técnico e à criação de novas instituições por meio da contratação de consultorias especializadas. As quatro OSCIPs parceiras indicadas na Tabela 3 são o Centro de Apoio aos Pequenos Empreendimentos do Maranhão (CEAPE-MA), a Ande (Visão Mundial), o Banco do Povo de Belo Horizonte e Empreenda!, organização atuante na capital de São Paulo.

101 M. M. Soares \& A. D. Melo Sobrinho Microfinanças: O papel do Banco Central do Brasil e a importância do cooperativismo de crédito, cit., p. 139. 
b) Organizações Não-Governamentais e Organizações da Sociedade Civil de Interesse Público

De acordo com o BCB (Tabela 2, supra), foram identificadas 143 entidades entre ONGs, OSCIPs e fundos públicos que, somados, atenderiam a 94.856 clientes tomadores de empréstimos de valor médio $\mathrm{R} \$ 724,47$, perfazendo um total de $\mathrm{R} \$ 68,72$ milhões.

Dentre tais atores, destaca-se o Sistema de Apoio aos Pequenos Empreendimentos, ou Sistema CEAPE, cuja unidade mais significativa é a do Estado do Maranhão (CEAPEMA), criada em 1989 e qualificada como OSCIP a partir de 1999. O CEAPE-MA presta seu atendimento por meio de 60 agências e um corpo de 200 funcionários. Em 20 anos de atividade, atendeu cerca 205 mil empreendedores e emprestou um volume total de R\$175 milhões, segundo números de final de 2008. É a maior OSCIP em atuação no Nordeste, e parcerias com a Associação Comercial do Maranhão, o Fundo das Nações Unidas para Infância e Adolescência (UNICEF), Fundação CODESPA (Espanha), Fundação Frederich Naumman (Alemanha), Acción International e Banco Interamericano de Desenvolvimento $(B I D)^{102}$. Em segundo lugar, no Sistema, o CEAPE Pernambuco (CEAP-PE) que, em fins de 2008, possuía uma carteira ativa de cerca de $\mathrm{R} \$ 6,5$ milhões e 3.588 clientes, e parceiros como BNDES, BID, UNICEF, Acción International, dentre outros ${ }^{103}$.

Outros atores relevantes que oferecem microcrédito produtivo orientado podem ser citados, como o Banco da Mulher, ONG fundada em 1984 e a mais antiga instituição de microcrédito sem fins lucrativos no Brasil. Foi declarada como utilidade pública federal, e hoje opera por meio de sete filiais (Manaus, Pelotas, Caxias do Sul, Uberlândia, Salvador, Curitiba e Rio de Janeiro, onde está instalada sua sede. O público feminino predomina dentre sua clientela (88\%), composta em grande parte de trabalhadoras informais $(74 \%)$, na faixa entre 21 e 56 anos, com renda entre 4 e 26 salários mínimos. O valor médio dos créditos concedidos é de $\mathrm{R} \$ 1.200,00$. São ainda características de sua clientela a escolaridade elevada ( $89 \%$ possui até o $2^{\circ}$ grau completo) e tempo de funcionamento de seu empreendimento, superior a dois anos (68\%).

\footnotetext{
102 www.ceapema.org.br

103 www.ceape-pe.org.br
} 
O programa São Paulo Confia, por meio de 12 postos de atendimento espalhados pela capital paulista, realizou 21.421 empréstimos a 10.401 microempreendedores de comunidades carentes no ano de 2008, totalizando o montante de R\$29,1 milhões. É considerado pioneiro na oferta de microcrédito produtivo orientado à população pobre do município de São Paulo, e sua metodologia foi inspirada no programa CrediAmigo. Possui como parceiros BNDES, Banco do Nordeste, a Caixa Econômica Federal e o Sebrae, dentre outros. Seu conselho de administração é integrado pelo Santander Banespa e ainda pelos seguintes entes: Secretaria do Trabalho do Município de São Paulo (controladora do Programa São Paulo Confia), Departamento Intersindical de Estatísticas e Estudos Socioeconômicos (DIEESE), Associação Brasileira de Empresários pela Cidadania (CIVES), Central Única dos Trabalhadores (CUT), Instituto de Tecnologia Social (ITS), Confederação Geral dos Trabalhadores (CGT), Central Autônoma dos Trabalhadores (CAT) e Social Democracia Sindical (SDS) ${ }^{104}$.

Ressalte-se que as experiências ora relatadas quanto a participação de OSCIPs no segmento leva em conta informações fornecidas, em grande parte, pelas próprias instituições. A disponibilização pública de dados e relatórios anuais relativos às suas operações é feita por pequeno número das OSCIPs em operação no país, e especialmente por aquelas que recebem recursos públicos e privados para a consecução de suas atividades, e que portanto detêm maior escala e visibilidade social. Pesquisa publicada no final de 2008 sobre as OSCIPs brasileiras dá conta de que este se trata de um segmento bastante concentrado: oito organizações pesquisadas deteriam cerca de 9,77\% do crédito ativo do mercado ( $\mathrm{R} \$ 28,3$ milhões) e 36.314 clientes, o equivalente a $11,21 \%$ da clientela do segmento. Outras 113 organizações deteriam 11,2\% do crédito ativo e $15,45 \%$ da clientela, o que significa uma média de 443 clientes e R\$ 288 mil de carteira ativa por $\operatorname{organização~}^{105}$.

c) Bancos públicos e Programa CrediAmigo

Algum detalhamento quanto à parceria do BNB e da OSCIP Nordeste Cidadania, aos serviços microfinanceiros oferecidos e à metodologia empregada pelo Programa

\footnotetext{
${ }^{104}$ www.saopauloconfia.org.br

${ }^{105}$ M. Monzoni, Impacto em renda do micrédito, p. 81.
} 
CrediAmigo foram vistos no item 2.2, a.3. O presente tem por fim expor alguns números sobre a estrutura e os serviços prestados pelo Programa.

O CrediAmigo presta microcrédito produtivo e orientado diretamente à população de baixa renda, por meio de metodologia específica para regiões urbanizadas. Atua por meio de unidades independentes e para tanto possui um corpo de técnicos especializados, que são contratados pela OSCIP Nordeste Cidadania, para $\mathrm{o}$ atendimento $\mathrm{e}$ acompanhamento de seus clientes:

Tabela 5

\begin{tabular}{lc}
\hline \multicolumn{1}{c}{ Estrutura de pessoal Ago/08 } & Quantidade \\
\hline Ambiente de microfinanças & 38 \\
Gerências de microfinanças & 12 \\
Funcionários de gerências & 03 \\
Equipe das agências & 1518 \\
$\quad$ - coordenadores & 224 \\
$\quad$ - administrativo & 333 \\
$\quad$ - crédito & 961 \\
Assessores regionais/sede & 66 \\
\hline Total de empregados no programa & 1637 \\
\hline Fonte: Área de Microfinanças e Programas Especiais do Banco do Nordeste do Brasil S/A.
\end{tabular}

O programa se estende por toda a Região Nordeste e norte de Minas Gerais. Em dezembro de 2007, contava com 1.481 municípios assistidos por 170 agências e 53 postos de atendimento. Dentre os municípios atendidos, 1.314 possuíam mais de 20 clientes ativos, e 167 menos de 20 clientes ativos.

Dentre os serviços microfinanceiros oferecidos (conta corrente normal e simplificada, seguro de vida, seguro prestamista), sem dúvida o que mais atrai a atenção é o microcrédito produtivo orientado, concedido a grupos solidários, o que, segundo a metodologia do programa, é uma estratégia para minimizar riscos. As condições para a obtenção de crédito junto ao programa seguem resumidas:

- Grupos solidários:

-03 a 10 microempreendedores e 01 ano de atividade. 
- Bancos comunitários:

-15 a 30 microempreendedores solidários, inclusive aqueles com menos de 01 ano de atividade ou que queiram iniciar nova, ou ainda que tenham restrições cadastrais.

-há a realização de reuniões prévias para conscientização do grupo sobre a tomada do empréstimo;

-estímulo ao 'empoderamento' dos integrantes ${ }^{106}$;

-indicação de 3 representantes para o grupo;

-exigência de formação de poupança proporcional ao valor do crédito recebido;

-a decisão sobre os valores entregues a cada integrante é do grupo, não é realizada avaliação financeira individual pelo programa;

-reuniões mensais para o pagamento das parcelas e acompanhamento das atividades do grupo;

-em comparação às demais linhas do programa, os valores médios dos empréstimos são mais baixos.

-Valores iniciais:

- clientes de bancos comunitários: até $\mathrm{R} \$ 300,00$

- clientes de subsistência: até R\$500,00

- clientes de acumulação simples: até R\$1.000,00

- clientes de acumulação ampliada: até R \$2.000,00

- Taxas de juros:

- capital de giro $\left\{\begin{array}{l}\text { valores até } \mathrm{R} \$ 1.000,00-1,95 \%, \text { TAC de até } 3 \% \\ \text { valores acima de R\$ } 1.000,00-\text { de } 2 \% \text { a } 3 \%, \text { TAC de até } 3 \%\end{array}\right.$

- investimento fixo: valores de R\$ 100,00 a R \$ 5.000,00 - 2,95\%,TAC de até 3\%.

- Endividamento máximo de R\$10.000,00, limitado a:

- capital de giro: até R\$10.000,00

- investimento fixo: até R\$5.000,00

106 A expressão tem sido frequentemente utilizada em trabalhos sobre microfinanças. Resultado de transformação de termo da língua inglesa ('empowerment'), e é empregada com o sentido de processo de busca e construção do poder (em geral) e do poder de decisão (em particular) de grupos oprimidos socialmente. 
- Prazo:

- capital de giro: 1 a 6 meses

- investimento fixo: até 36 meses

Entre janeiro de 2003 e agosto de 2008, o programa atendeu a 3.678.732 empréstimos de valor médio $\mathrm{R} \$ 933,77$, resultando num montante aplicado de $\mathrm{R} \$ 3,4$ bilhões. Em 2008, até o dia 31 de agosto, o Crediamigo havia realizado $625.176 \mathrm{mil}$ empréstimos, de valor médio R \$ 1.029,90, perfazendo o valor aplicado de R $\$ 643,8$ milhões. No período compreendido entre 2002 e agosto de 2008 a inadimplência, (mensurada a partir de um dia) obedeceu ao gráfico a seguir:

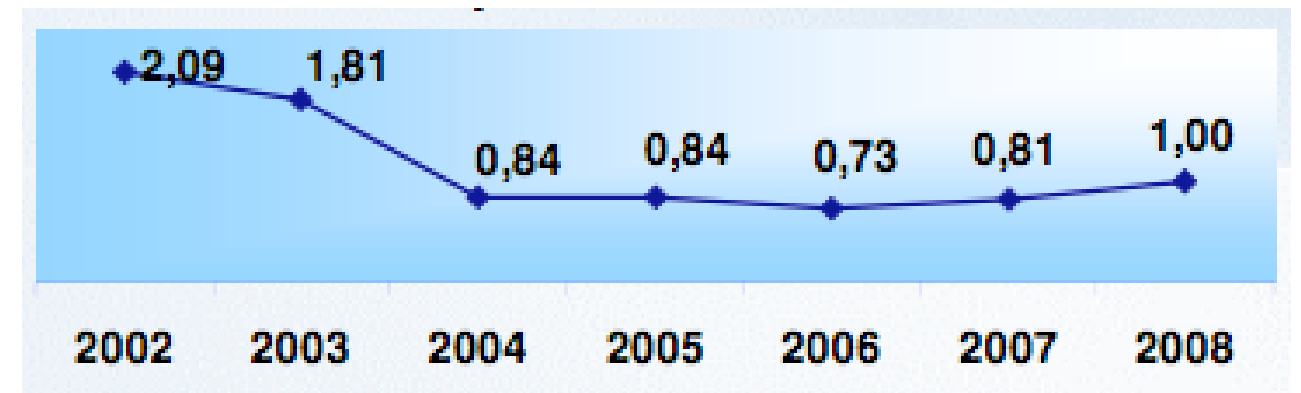

Um a noventa dias de atraso sobre a carteira ativa de até 90 dias.

Fonte: Área de Microfinanças e Programas Especiais do Banco do Nordeste do Brasil S/A.

O programa atribui o baixo índice de inadimplência ao trabalho desenvolvido junto aos grupos de tomadores pelos seus agentes de crédito. Em suma, aplica-se a metodologia do crédito produtivo orientado desde o processo de negociação para a contratação do empréstimo, o acompanhamento do negócio pelo agente de crédito, visita no dia anterior ao vencimento da parcela e assessoria empresarial e educação financeira. De acordo com sua "cultura de inadimplência zero", os casos de inadimplência são tratados com visitas do agente de crédito, coordenador da agência local, avisos pelos Correios e sanções sociais.

Segue a suma dos indicadores do programa: 
Tabela 6

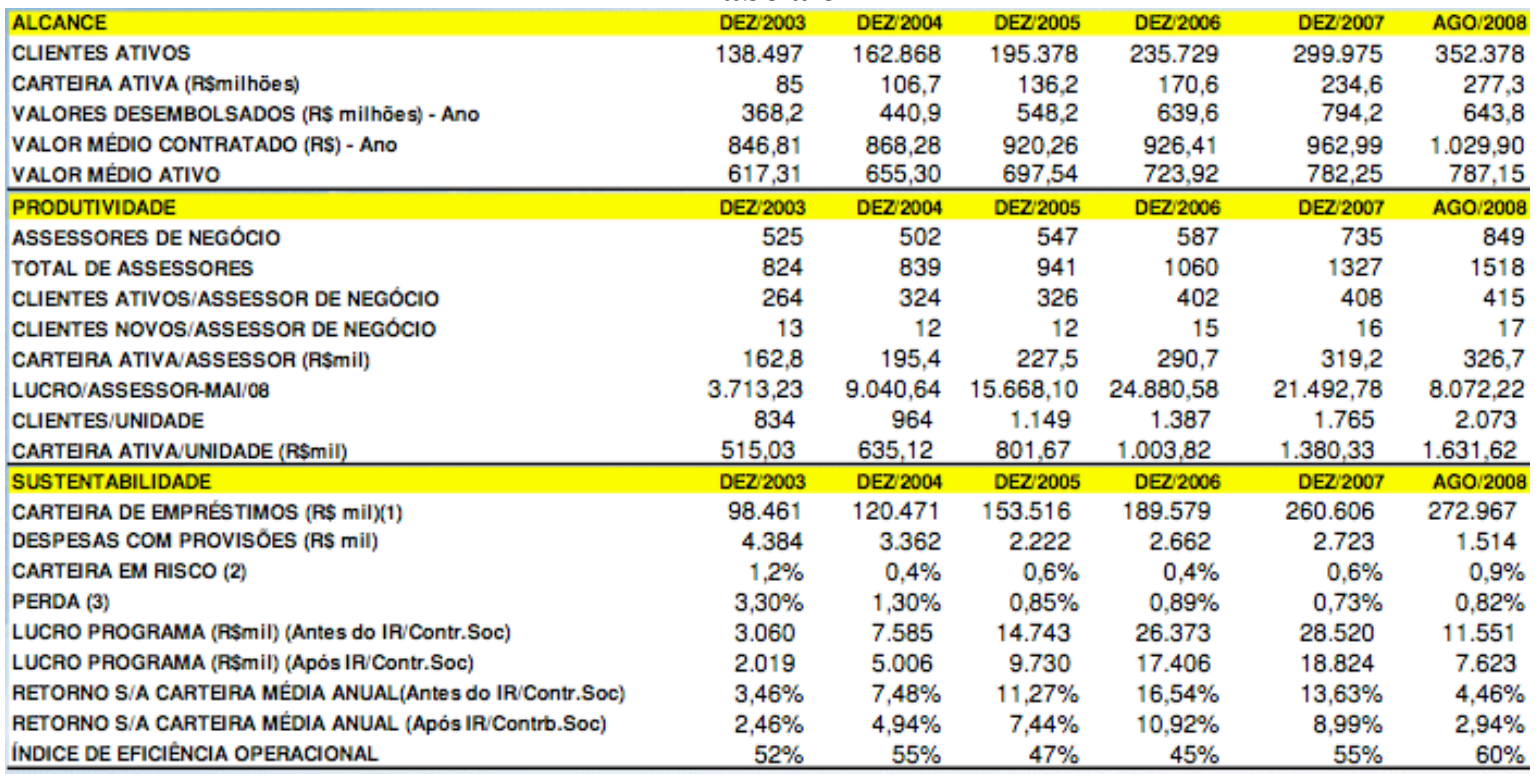

(1) Considera a soma dos empréstimos normais ou em atraso até 360 dias (contábil) incluindo rendas a apropriar.

(2) Valores das operações em atraso entre 30 e 90 dias / carteira total de empréstimos (360 dias).

(3) Incremento de parcelas em atraso acima de 90 dias / carteira total de empréstimos (360 dias).

Fonte: Área de Microfinanças e Programas Especiais do Banco do Nordeste do Brasil S/A.

Segundo dados do BCB de dezembro de 2007, o Programa AgroAmigo, criado mais recentemente pelo BNB para atender pequenos produtores rurais sob metodologia semelhante à do CrediAmigo, havia aplicado cerca de $\mathrm{R} \$ 500$ milhões em quase 400 mil operações de crédito realizadas em 992 municípios da região Nordeste, norte de Minas Gerais e norte do Espírito Santo.

Outro banco público a ser destacado é o Banco Popular do Brasil (BPB), braço microfinanceiro do Banco do Brasil, antes voltado para serviços microfinanceiros em geral como, por exemplo, seguros de vida de baixo custo e crédito para consumo, e que no primeiro semestre de 2007 criou sua carteira de microcrédito produtivo orientado, amparada no PNMPO, relatado a seguir, no Capítulo 3.

d) Cooperativas de crédito

Sua distribuição pelas regiões brasileiras se dá segundo as seguintes proporções: 6\% estão localizadas no Norte, $9 \%$ no Centro Oeste, $10 \%$ no Nordeste, $20 \%$ no Sul e 55\% no Sudeste. Segundo dados de junho de 2008 do BCB, o cooperativismo de crédito estaria presente em $37 \%$ dos municípios brasileiros. A distribuição obedece à critérios históricos 
de concentração de renda, sendo mantida ao longo das décadas a exclusão das regiões e municípios mais carentes.

O atual quadro das cooperativas no país, segundo números de junho de 2008, é composto de 1.423 cooperativas singulares, 38 cooperativas centrais e 4 confederações, sendo que três destas últimas pertencem ao do setor de serviços (Sicoob Brasil, Sicred Serviços e Confebrás) e uma de crédito (Unicred Brasil).

O perfil vertical concentrava o maior número de cooperativas de crédito brasileiras (63\%), composto pelos sistemas Sicoob Brasil, Sicred Serviços e Unicred Brasil ${ }^{107}$, e integrado pelas três confederações, 899 cooperativas singulares e 28 cooperativas centrais.

Por sua vez, o perfil horizontal era integrado por 251 cooperativas singulares e dez centrais, e pode ainda ser subdividido em dois, um primeiro formado por 5 centrais e 56 cooperativas singulares em que estão presentes cooperativas dos ramos empresarial, rural, voltadas ao meio urbano e a segmentos de funcionários públicos, e um segundo, ligado ao movimento de agricultura rural com interação solidária, em que nasceram as primeiras cooperativas da espécie, sob a marca 'Cre\$ol', e deu origem à Associação Nacional de Cooperativismo de Crédito de Economia Familiar e Solidária (Ancosol), que congrega cinco cooperativas centrais e 195 cooperativas solidárias atuantes em São Paulo, Paraná, Santa Catarina, Rio Grande do Sul e, a partir de 2008, Bahia. A expectativa é que a Ancosol se torne uma confederação, confirmando a tendência de verticalização por meio de fusões e incorporações e aumento de amplitude operacional por meio dos chamados Postos de Atendimento Cooperativo (PACs), como forma de agregar maior eficiência, capacidade organizacional e operacional ao bloco.

Quanto ao alcance da atuação das cooperativas, sugerem-se dois focos de análise: um primeiro quantitativo, que indica a predominância de cooperativas urbanas com público alvo segmentado: 57\% são de empregados e profissionais (com claro predomínio da área médica), e $27 \%$ de crédito rural e interação solidária. Sob o enfoque das operações de crédito e depósitos realizadas, em primeiro lugar figuram as cooperativas de livre admissão (que, como visto, funcionam de modo similar à instituições bancárias

\footnotetext{
${ }^{107}$ A Confebrás é desconsiderada pela sua intersecção com outros sistemas.
} 
comerciais), seguidas das cooperativas urbanas com público alvo segmentado, com forte participação dos profissionais de saúde. Nesse quesito, perdem força as cooperativas crédito de rural e interação solidária, por conta dos pequenos valores movimentados e da maior carência de recursos.

Por fim, cumpre salientar que, apesar da clara concentração em determinadas regiões e segmentos mais abastados economicamente, o cooperativismo tem papel decisivo como indutor de desenvolvimento local em alguns municípios, como se percebe no Sul do país. A despeito dos números, importa observar a viabilização do acesso a serviços financeiros a baixo custo, com transparência e qualidade.

\subsection{Debates e dilemas}

Descarta-se, de pronto, o debate sobre o papel do Estado e se este é eficaz ou não quando atua diretamente em setores que, em tese, a cargo da iniciativa privada apresentariam melhores índices. Não se pretende com isso ignorar o debate, mas, como visto, o principal programa de microcrédito auto-sustentável do país foi construído pela iniciativa de um banco público, e o próximo capítulo trata justamente das políticas públicas de inclusão social concebidas pelo Estado como forma de incentivar a geração de trabalho e renda entre a população alijada do mercado de trabalho formal.

Por outro lado, na contraposição entidades sem fins lucrativos vs. bancas comerciais, há alguns pontos passíveis de serem destacados. Por exemplo, quanto à eficiência e capacidade para gerar mudanças, no nível nacional, das primeiras, na medida em que o impacto de iniciativas locais passa desapercebido em um país de dimensões continentais; quanto à efetividade da capacitação e o baixo interesse dos tomadores, que a ela se submeteriam apenas para receber o crédito, dentre outros.

Talvez o debate que seja capaz de melhor refletir o dilema que atualmente permeia o setor diga respeito à incerteza quanto ao futuro das instituições microfinanceiras organizadas sob a forma de ONGs e OSCIPs, coadjuvantes de políticas sociais empreendidas pelo poder público. Há opiniões dentro do Banco Mundial a sustentar a manutenção da ação localizada das mesmas, em contraposição ao seu agigantamento e massificação de seus serviços para fazer frente à concorrência das bancas comerciais e suas 
recém-criadas carteiras de microcrédito. Segundo tal opinião, os ganhos pelo oferecimento de serviços em escala por essas entidades não seriam compensadores da perda de qualidade na sua prestação e do desvirtuamento de seus objetivos e ambições que são, por regra, locais e atingidos apenas no médio ou longo prazo. Em consonância ao que prega a corrente minimalista, os primeiros custos a serem cortados seriam justamente aqueles relativos à capacitação e educação financeira dos tomadores, pois implicam a essas entidades custos operacionais superiores aos das bancas comerciais por unidade de crédito concedido. Em suma, entende-se que essas instituições sem fins lucrativos não seriam vocacionadas a concorrer em um mercado em que o poder econômico dos bancos comerciais é evidente, mas sim a atender nichos específicos e realizar sua missão ${ }^{108}$.

A questão, sem dúvida controversa, é combatida pelos que defendem o crescimento das instituições sem fins lucrativos como condição de sua sobrevivência, seja por meio de fusões tendentes a aumentar sua capacidade e o impacto de suas ações, seja por meio de parcerias com SCMs, como forma de ampliar o leque de serviços que as primeiras, entidades não pertencentes ao Sistema Financeiro Nacional, podem oferecer ${ }^{109}$.

Por fim, há o dilema já mencionado sobre o paradoxo da existência de vultuosos recursos disponíveis (e não aplicados) vs. uma enorme demanda não atendida do lado das entidades não integrantes do Sistema Financeiro Nacional. O problema se tornaria nítido no caso da maioria das OSCIPs, que não conseguem acessar tais recursos. As respostas possíveis seriam muitas, como aquelas atinentes à sua profissionalização, autosustentabilidade, transparência, uniformização de padrões contábeis etc.

Como frisado ao final do Capítulo 1, esta dissertação não tem a pretensão de apresentar respostas prontas a tais dilemas, e seu esforço se concentra em compreender qual o ambiente normativo em que se desenvolvem tais relações, e refletir se os entraves enfrentados por tais instituições de fato se devem a tal ambiente. Como ponderado no item final daquele capítulo, a dificuldade em lidar com um conjunto de múltiplas regras, por vezes aparentemente confusas e intrincadas, não parece ser favorável à atuação das

\footnotetext{
${ }^{108}$ Posição abertamente defendida por Terence Galagher, do International Finance Corporation, e Manuel Thedim, do Fórum Brasileiro de Microfinanças, durante o VII Seminário BACEN Microfinanças realizado em Belo Horizonte entre os dias 29 de setembro e $1^{\circ}$ de outubro de 2008.

109 Argumento recorrente durante o Seminário supra citado, defendido por alguns representantes do BCB, governo federal e especialistas.
} 
entidades, especialmente àquelas que não são reguladas pelo Sistema Financeiro Nacional e passam a ter a necessidade de desenvolver suas atividades "com um pé em cada barco", ora atentas à sua finalidade social, ora atentas à perseguição de divisas, para tanto precisando lidar com dois ambientes regulados por normas de diferente caráter, pertencentes ao chamado Terceiro Setor e ao Sistema Financeiro Nacional. Talvez, e com esta afirmação não se tenciona realizar julgamentos, a presteza em alcançar um ponto de equilíbrio em que se entrecruzam tais esferas seja algo ainda não alcançado por essas entidades, ou mesmo pela autoridade reguladora. 


\section{CAPÍTULO 3 \\ MICROFINANÇAS \& POLÍTICAS PÚBLICAS}

O OBJETIVO DESTE CAPÍtUlO É OBSERVAR COMO O ARCABOUÇO JURíDICO DAS MICROFINANÇAS E, EM ESPECIAL, O MICROCRÉDITO PRODUTIVO ORIENTADO, TÊM SIDO ARTICULADOS A POLÍTICAS PÚBLICAS E PROGRAMAS DE SUPERAÇÃO DA POBREZA.

\subsection{Introdução}

Os capítulos anteriores procuraram traçar, considerados os limites do presente trabalho, um panorama das microfinanças no país. As discussões que envolveram a concepção do marco regulatório e alguns de seus principais atores. Seu público-alvo e agentes prestadores de serviços microfinanceiros no país. Foram destacadas quais as principais diferenças entre as formas jurídicas aptas a viabilizar a prestação desses serviços, o fins a que se destinam, pontos fortes e fragilidades. Por fim, qual o ambiente institucional em que esses agentes se movem e fazem mover, na medida em que sua atuação e desempenho são atentamente medidos e estudados, de modo a resultar, periodicamente, em nova medida da autoridade reguladora no plano normativo. Ainda que os movimentos desse processo dinâmico não tenham sido pormenorizados por completo, espera-se que algumas de suas mais importantes cenas tenham sido reveladas.

\subsection{Atuação concertada dos atores que formulam e executam políticas}

Da mesma forma que a regulação do sistema financeiro requer o olhar atento e a resposta imediata da autoridade reguladora para realizar os ajustes contínuos tendentes ao seu aperfeiçoamento, a elaboração de uma política pública que articule diferentes instrumentos jurídicos, concebidos no bojo de subsistemas distintos, requer que seus formuladores sejam capazes de cooperar ao longo de seu processo de maturação. No caso de políticas públicas de cunho social que utilizam as microfinanças como instrumento de superação da pobreza, pode-se mesmo falar em um processo dinâmico para o qual não existe um ponto final, e do qual depende o sucesso da política ou do programa. 
Há diversos atores e instituições, que mesmo não estudados a fundo, foram ao menos mencionados no decorrer deste trabalho, por exercerem influência determinante sobre o panorama das microfinanças no Brasil: Ministério da Fazenda, Ministério do Desenvolvimento Social, BCB, BNDES, bancos federais, Sebrae, FAT e Pronaf, organismos internacionais, organizações da sociedade civil, bancas comerciais, empresas públicas (como a ECT), governos estaduais e municipais, órgãos da administração pública.

As articulações entre esses entes no decorrer dos últimos anos possibilitou que começasse a se delinear no país uma nova forma de construção de políticas públicas de cunho social: aquelas que se utilizam de soluções de mercado, orientadas para o atendimento de interesses que vão além da mera especulação lucrativa. Isso sem que venha a ser prejudicada a livre iniciativa daqueles que desejam apenas e tão somente explorar uma atividade lucrativa, como é o caso das bancas comerciais. A construção do marco regulatório e de constantes aperfeiçoamentos quanto ao arcabouço regulatório do setor, com a participação dos atores envolvidos no financiamento e na prestação de serviços microfinanceiros tem dado mostras de que é possível, a muitas mãos, construir um setor em que é desempenhada uma atividade econômica que precipuamente atenda à população mais carente de ações do poder público para sua sobrevivência.

Essa é uma percepção que se tornou cada vez mais forte no decorrer da pesquisa, e que poderá ser negada ou confirmada a partir da observação da condução do Programa Nacional de Microcrédito Produtivo Orientado pelo Ministério do Trabalho e Emprego, e seu acompanhamento pelo BCB e pelo BNDES ao longo dos próximos anos. Portanto, para os fins a que se propõe este estudo, não é o bastante olhar para determinada norma ou, como é o caso, para o PNMPO, tal como consubstanciado na Lei n. 11.110/05 e apontar se, além de formalmente de acordo com o devido processo legislativo que a introduziu no ordenamento como norma válida, eficaz e apta a produzir efeitos, consubstancia o instrumento adequado ao uso das microfinanças como uma política pública virtuosa. Dito de outro modo, "para que seus resultados sejam eficazes, as políticas públicas requerem muito mais do que um momento mágico na política que gere 'a política pública correta" $^{\prime 110}$.

\footnotetext{
${ }^{110}$ A política das políticas públicas - Progresso econômico e social na América Latina: Relatório 2006, Banco Interamericano de Desenvolvimento e David Rockefeller Center for Latin American Studies, Harvard
} 
Na medida em que as políticas são respostas contingentes à situação de um país em um dado momento, supõe-se, para fins deste estudo, que as políticas devem ser construídas a partir de uma seqüência infindável de 'momentos mágicos', derivados da atuação concertada dos atores que formulam e executam políticas.

Sob esse enfoque, uma possível abordagem para o tema, no momento, é a de observar como foram articulados, por ocasião da concepção do PNMPO, os instrumentos derivados do marco regulador das microfinanças e da capacidade regulamentar do BCB, bem como as medidas de apoio, financiamento e fortalecimento institucional do setor microfinanceiro formuladas pelo BNDES. Espera-se que o papel do BCB no plano regulatório tenha sido suficientemente analisado nos capítulos anteriores. O item 3.3, a seguir, relata algumas medidas do BNDES para o desenvolvimento da infra-estrutura do setor microfinanceiro, bem como alguns divulgados pelo seu Departamento de Economia Solidária e Área de Inclusão Social.

Os primeiros passos para a implementação do PNMPO começaram a ser dados há três anos, a partir dos trabalhos de um Comitê Interministerial composto pelo Ministério do Trabalho e Emprego e Emprego, Ministério da Fazenda e Ministério do Desenvolvimento Social Combate à Fome. Sua participação no PNMPO e as principais diretrizes do programa são expostas a seguir.

\subsection{Arcabouço institucional do PNMPO}

O PNMPO foi instituído no âmbito do Ministério do Trabalho e Emprego e Emprego, sob as finalidades de promover o incentivo de geração de trabalho e de renda por meio da ampliação do acesso ao crédito a microempreendedores formais e informais, bem como integrar o microcrédito às demais políticas de desenvolvimento social promovidas pelo Estado com a participação da sociedade civil. Atua por meio de uma rede de instituições de microcrédito habilitadas junto ao MTE e, portanto, para que o programa alcance seus objetivos, faz-se necessário o fortalecimento e ampliação de uma rede autônoma e perene de financiamento da economia popular. Decisivo, para tanto, o papel do BCB e do BNDES na interlocução entre os agentes prestadores de serviços

University, tradução Banco Interamericano de Desenvolvimento. Rio de Janeiro: Elsevier, Washington DC: BID, 2007, $2^{\mathrm{a}}$ reimpressão, p. 15. 
microfinanceiros e o programa, para que as condições técnicas e regulamentares necessárias à atuação dos agentes e da persecução dos fins da política se ajustem adequadamente quanto às suas eventuais falhas e mudança das circunstâncias que a envolvem, resultando enfim em ações bem coordenadas entre os atores que participam da sua formulação e implementação.

a) Estrutura e metodologia

A estrutura operacional do PNMPO, como não poderia deixar de ser, é integrada por diversos agentes, já vistos com algum detalhamento no Capítulo 2 e qualificados segundo seu papel no âmbito do programa:

- Instituições Financeiras Operadoras (IFO) - bancos públicos que operam recursos de depósitos especiais do Fundo de Assistência ao Trabalhador (FAT) uma das fontes de financiamento do PNMPO. Segundo determina a Lei n. 8.019/90, são o Banco do Brasil, a Caixa Econômica Federal, o Banco do Nordeste, o Banco da Amazônia e o BNDES; e ainda instituições financeiras que operam a parcela de $2 \%$ de depósitos à vista a ser direcionada a atividades que envolvam microcrédito produtivo orientado (bancos comerciais, bancos múltiplos com carteira comercial e os bancos públicos);

- Instituições de Microcrédito Produtivo Orientado (Impo): cooperativas de crédito singulares, agências de fomento, sociedades de crédito ao microempreendedor, organizações da sociedade civil de interesse público. A qualidade de Impo é obtida mediante cadastro, termo de compromisso e habilitação junto ao Ministério do Trabalho e Emprego; e

- Agentes de Intermediação (AGI): bancos de desenvolvimento, agências de fomento, bancos cooperativos e cooperativas centrais de crédito que atuam como repassadoras de recursos das Instituições Financeiras Operadoras para as Instituições de Microcrédito Produtivo Orientado.

Segundo a estrutura operacional concebida pelo PNMPO, as Instituições de Microcrédito Produtivo Orientado (Impo) realizam contratação direta com o microempreendedor, utilizando sua própria infra-estrutura. As Instituições Financeiras 
Operadoras (IFO), por sua vez, podem conceder empréstimos diretamente ao microempreendedor ou por meio de instrumento de mandato firmado com as Impo. Estas são financiadas, por repasse de recursos do FAT e parcela do direcionamento de $2 \%$ dos depósitos à vista a atividades de microcrédito. Esse repasse pode ser feito diretamente das IFOs para as Impos ou via Agente de Intermediação (AGI). Pode haver ainda a compra da carteira de operações das Impos pelas IFOs, de forma direta ou por via dos AGIs. Por fim, há a destinação de recursos do orçamento público para o fortalecimento institucional das Impos.

A metodologia para concessão de crédito pode ser sintetizada como o relacionamento direto entre a instituição de microcrédito produtivo orientado e o empreendedor, intermediado pelo agente de crédito. As informações colhidas pelo agente de crédito são determinantes para o valor e as condições do empréstimo a ser concedido, bem como direcionam o atendimento prestado quanto à capacitação técnica e educação financeira do microempreendedor. Suas características são a seguir detalhadas:

i) o contato entre o agente de crédito e o tomador se dá no local em que é desempenhada a atividade econômica;

ii) o agente de crédito é treinado para efetuar levantamentos socioeconômicos e prestar orientação educativa sobre o planejamento do negócio, para definição das necessidades de crédito e de gestão voltadas para o desenvolvimento do empreendimento;

iii) o contato do agente de crédito com o empreendedor deve ser mantido durante o período do contrato de crédito, visando ao seu melhor aproveitamento e aplicação, bem como ao crescimento e sustentabilidade da atividade desempenhada; e

iv) o valor e as condições do crédito devem ser definidas após a avaliação da atividade e da capacidade de endividamento do tomador dos recursos, em estreita interlocução com este ${ }^{111}$.

\footnotetext{
${ }^{111}$ Fonte: $\underline{w w w} \cdot \mathrm{mte} . \mathrm{gov} \cdot \mathrm{br} / \mathrm{pnmpo}$.
} 
b) Desempenho

Passou a ser medido a partir de 2005, com a implantação do programa, cujo objetivo é atender a microempreendedores populares, definidos como pessoas físicas ou jurídicas empreendedoras de atividades produtivas de pequeno porte, formais e informais, com renda bruta anual de até R\$ 60 mil. Segundo dados do MTE, em 2007 foram realizadas 963.459 novas operações de microcrédito produtivo orientado, que concederam empréstimos de valor médio R\$1.142,11 a 513.032 microempreendedores.

Quanto ao número de instituições habilitadas perante o MTE desde o surgimento do programa, destacam-se as cooperativas (cerca de $45 \%$ do total das Impos) e OSCIPs (cerca de $43 \%$ ), conforme mostra o quadro a seguir:

\begin{tabular}{lcccc}
\hline \multicolumn{1}{c}{ Instituições } & $\mathbf{2 0 0 5}$ & $\mathbf{2 0 0 6}$ & $\mathbf{2 0 0 7}$ & $\mathbf{2 0 0 8}^{\mathbf{1}}$ \\
\hline Cooperativas & 40 & 90 & 103 & 114 \\
OSCIPs & 0 & 100 & 120 & 122 \\
SCMs & 10 & 16 & 16 & 17 \\
Instituições Financeiras Operadoras & 0 & 3 & 3 & 3 \\
Agências de Fomento & 2 & 4 & 5 & 6 \\
Cooperativas Centrais & 0 & 2 & 4 & 4 \\
Banco Cooperativo & 0 & 1 & 1 & 1 \\
\hline Total & 52 & 216 & 252 & 267 \\
\hline
\end{tabular}

${ }^{1}$ Habilitações obtidas junto ao MTE até 7 de agosto de 2008.

Fonte: MTE/PNMPO.

Sua distribuição regional indica que o Sul do país concentra a maior parcela das instituições habilitadas (cerca de 49\%), seguida pelo Sudeste (cerca de 23\%):

\begin{tabular}{|l|cccc|ccc|c|}
\hline \multirow{2}{*}{ Região } & \multicolumn{4}{|c|}{ Impo } & \multicolumn{3}{c|}{ AGI } & \multirow{2}{*}{ Total } \\
\cline { 2 - 8 } & Oscip & SCM & IFO & $\begin{array}{c}\text { Coop. } \\
\text { Créd. }\end{array}$ & AF & $\begin{array}{c}\text { Coop. } \\
\text { Central }\end{array}$ & $\begin{array}{c}\text { Bco } \\
\text { Coop. }\end{array}$ & \\
\hline S & 37 & 2 & - & 85 & 2 & 4 & 1 & 131 \\
SE & 33 & 14 & 1 & 13 & - & - & - & 61 \\
NE & 30 & 1 & 1 & 17 & 2 & - & - & 51 \\
N & 8 & - & 1 & 1 & 2 & - & - & 12 \\
CO & 6 & - & - & 6 & - & - & - & 12 \\
\hline \multicolumn{1}{c}{ Total } & 114 & 17 & 3 & 122 & 6 & 4 & 1 & 267 \\
$\quad \%$ & $42,7 \%$ & $6,37 \%$ & $1,12 \%$ & $45,69 \%$ & $2,25 \%$ & $1,50 \%$ & $0,37 \%$ & $100 \%$ \\
\hline
\end{tabular}

Fonte: MTE/PNMPO, agosto de 2008.

Quanto à carteira ativa de microcrédito produtivo orientado, dados indicam que, em 2007 , cerca de $77,8 \%$ de seus valores totais foram destinados ao financiamento de capital 
de giro dos microempreendedores, $17,3 \%$ ao investimento fixo e $4,9 \%$ a financiamentos mistos. Por setor de atividade, 77,62\% beneficiaram empreendimentos comerciais, $14,54 \%$ foram direcionados a prestadores de serviços, 4,97\% a microempreendimentos produtivos ou industriais, 1,69\% a microempreendedores agrícolas e 1,18\% a outros. A evolução da sua carteira ativa desde a criação do PNMPO é resumida na tabela a seguir:

\begin{tabular}{lrrrr}
\hline \multicolumn{1}{c}{ Carteira } & \multicolumn{2}{c}{$\mathbf{2 0 0 5}$} & \multicolumn{2}{c}{$\mathbf{2 0 0 7}$} \\
\hline Microcrédito produtivo orientado & $63.593 .613,29$ & $84 \%$ & $502.196 .847,31$ & $84 \%$ \\
Trocas de cheques (factoring) & - & - & 20.098 .364 .76 & $3 \%$ \\
Outras carteiras ativas & $11.970 .834,21$ & $16 \%$ & $76.660 .799,23$ & $13 \%$ \\
\hline Total & $75.564 .447,50$ & $100 \%$ & $598.956 .011,30$ & $100 \%$ \\
\hline
\end{tabular}

Fonte: MTE/PNMPO, 2008.

c) Papel do BNDES no PNMPO

Como já indicado no Capítulo 1 (item 1.3,a), vem de longa data a participação do BNDES no fomento à formação de uma indústria microfinanceira no país, cujo objetivo se concentrou na criação das condições institucionais e fortalecimento dos agentes prestadores de serviços para a sua oferta em larga escala, com ênfase na autosustentabilidade dos agentes repassadores.

Desde 1996, podem ser destacados o Programa de Crédito Produtivo Popular (PCPP) voltado especialmente a OSCIPs e SCMs, que até 2003 apoiou 32 instituições microfinanceiras, com recursos da ordem de R \$43,3 milhões. No período, cerca de 160 mil operações de microcrédito foram realizadas, em um montante aproximado de R 185 milhões. Nesse mesmo período, em 1997, foi firmado convênio de cooperação técnica com o BID, e criado o Programa de Desenvolvimento Institucional (PDI). No âmbito desse convênio foram apoiadas seis instituições, que receberam, somadas, R \$ 3,7 milhões para investimentos em equipamentos, sistemas de informação gerencial e capacitação.

Área de Inclusão Social do BNDES, a partir de 2005, passou a atuar com foco no aprofundamento do caráter intersetorial e na compreensão dos aspectos territoriais da atuação social, por meio da busca de articulação entre diferentes setores da sociedade civil e do setor público. Desde então, o atual Programa de Microcrédito (PMC) passou a 
coordenar esforços e ações com os demais órgãos envolvidos no PNMPO. Em relação à demais linhas de apoio do BNDES, o PMC inova ao aceitar os ativos gerados pela carteira de crédito dos agentes repassadores como garantia das operações. O PMC ainda realiza operações com agentes repassadores credenciados como agentes financeiros do BNDES. São eles bancos cooperativos, cooperativas centrais de crédito e agências de fomento, os chamados agentes de segundo piso, que repassam recursos para agentes prestadores de serviços em primeiro piso, i. e, que fornecem crédito diretamente com os microempreendedores porém não reúnem as condições necessárias para acessar o PMC diretamente. A partir de 2007 o PMC passou a realizar operações com instituições de primeiro piso fundamentais na disseminação de microcrédito produtivo orientado, as cooperativas singulares de crédito.

A distribuição regional das aprovações de recursos do PMC até julho de 2008 obedecia à seguinte proporção: $50,3 \%$ dos recursos eram destinados ao Sul; 37,4\% ao Nordeste; $10,9 \%$ ao Sudeste e $1,4 \%$ ao Centro Oeste. Segundo números da Área de Inclusão Social do BNDES, das 38 instituições apoiadas, quatro são agentes de segundo piso, que atuam no repasse de recursos a 180 instituições que prestam serviços diretamente a microempreendedores. Até julho de 2008, a carteira do PMC havia realizado R\$ 154 milhões em operações, dentre os quais R 107 milhões seriam destinados a projetos aprovados às 38 instituições referidas. Desse último montante, $\mathrm{R} \$ 65,3$ milhões já teriam sido efetivamente liberados aos agentes repassadores (ou 61\% das operações contratadas até o momento).

Conforme apontado no Capítulo 2, item 2.4, a, Tabela 4, ao BNDES corresponde a parcela de $14,7 \%$ do total dos recursos investidos em microcrédito no país (R\$ 462.714 milhões). Quanto às instituições habilitadas junto ao MTE para operar microcrédito produtivo orientado sob a cobertura do PNMPO, o BNDES atingia, em julho de 2008, o grau de cobertura de $55 \%$ : 


\begin{tabular}{lccc}
\hline \multicolumn{1}{c}{ Instituições } & $\begin{array}{c}\text { Cadastradas no } \\
\text { PNMPO }\end{array}$ & $\begin{array}{c}\text { Atendidas pelo } \\
\text { PMC / BNDES }\end{array}$ & $\begin{array}{c}\text { Grau de } \\
\text { cobertura }\end{array}$ \\
\hline Agência de fomento & 6 & 2 & $33 \%$ \\
Banco comercial & 2 & 0 & $0 \%$ \\
Banco cooperativo & 1 & 1 & $100 \%$ \\
Cooperativas singulares & 122 & 116 & $95 \%$ \\
Cooperativas centrais & 4 & 2 & $50 \%$ \\
OSCIP $^{*}$ & 111 & 24 & $22 \%$ \\
SCM & 16 & 0 & $0 \%$ \\
\hline Grau de cobertura do BNDES & $\mathbf{2 6 2}$ & $\mathbf{1 4 5}$ & $\mathbf{5 5 \%}$ \\
\hline
\end{tabular}

* Considera as instituições atendidas pelo agentes repassadores ou de segundo piso. Fonte: BNDES.

Dentre os principais projetos apoiados pelo PMC/BNDES, destacam-se o Sistema Cre\$ol de Cooperativas de Crédito Rural com Interação Solidária (R\$ 14,5 milhões) Cooperativas Singulares em Minas Gerais - Sistema Sicoob (R\$ 8,6 milhões), além da Associação das Cooperativas de Apoio à Economia Familiar - Ascoob (R\$ 7,2 milhões).

d) Projetos e parcerias

No âmbito do Plano de Desenvolvimento Institucional do BNDES/BID para o setor microfinanceiro foi também celebrado convênio com o Ministério do Trabalho e Emprego no montante de R\$ 2,5 milhões para o Plano de Desenvolvimento Institucional do PNMPO, que por meio da realização de dez oficinas de trabalho com atores do setor, prioriza:

i) a criação de métodos de avaliação e análises que servissem ao aprimoramento da infra-estrutura do setor, como o desenvolvimento de um padrão de plano de contas e de indicadores de resultado para OSCIPs, com o objetivo de ampliar a transparência e comparabilidade do setor;

ii) $\mathrm{o}$ projeto 'Metodologia de Governança Institucional para Oscip de Microcrédito', com o objetivo de capacitar conselheiros e demais gestores de OSCIPs de microcrédito para o controle de suas atividades;

iii) o diagnóstico organizacional e setorial das Impos, para o fim de subsidiar a implementação de estratégias que viabilizem o incremento do uso sustentável das microfinanças no país; e 
iv) a sistematização de propostas para o aprimoramento dos chamados 'Marco Legal do Microcrédito Produtivo Orientado'.

Como forma de acompanhar a evolução do PNMPO, o MTE criou em 2007 um banco de dados permanente, a ser alimentado por informações fornecidas quadrimestralmente pela sua rede de instituições habilitadas, convocadas a disponibilizar um conjunto de dados relativos às suas operações. A cada exercício, as informações consolidadas ficam disponíveis ao público em geral no portal do PNMPO na internet.

Por fim, no contexto da a tendência de expansão de programas que entrelaçam mais de um benefício à população de baixa renda, o MTE pretende, em 2009, introduzir o microcrédito no Programa Bolsa Família, por meio de acordo de cooperação técnica com o Ministério do Desenvolvimento Social ${ }^{112}$ e parcerias com instituições de microcrédito habilitadas, incumbidas da seleção de potenciais pequenos empreendedores e concessão de crédito para suas atividades produtivas. Seriam duas as finalidades a serem atendidas: i) emancipar as famílias atendidas pelo Bolsa Família, ao substituir o repasse da renda pelo microcrédito; e ii) fortalecer as instituições operadoras de microcrédito produtivo orientado $^{113}$.

\subsection{Articulação das microfinanças a políticas públicas de superação da pobreza}

Como frisado no decorrer deste capítulo, tão importante quanto o desenho bem intencionado de ações no campo da promoção dos direitos sociais e econômicos é a definição clara de papéis dos órgãos incumbidos de formular e tornar possível a execução de seu conteúdo, sua fiscalização, acompanhamento de seus resultados e ajustes no decorrer do tempo. Importa, ainda, como condição para tanto, a existência de matrizes institucionais, a exemplo dos comitês e comissões interministeriais mencionados no decorrer deste trabalho, capazes de articular estrategicamente a atuação desses órgãos, suas competências e missões distintas, bem como os arcabouços normativos que condicionam a

112 Pesquisa realizada pelo Ministério do Desenvolvimento Social, identificou mais de um milhão de beneficiários do Bolsa Família que exercem alguma atividade produtiva.

${ }^{113}$ www.fomezero.gov.br/noticias/beneficiarios-do-bolsa-familia-contam-com-projeto-de-microcredito . 
atuação dos demais atores envolvidos nos programas e políticas. Nesse sentido, importa 'decidir quem decide' no campo das políticas públicas ${ }^{114}$.

O papel dessas matrizes institucionais está justamente em conferir caráter de política pública orgânica a diferentes programas criados no âmbito dos órgãos da administração pública. A existência de tais matrizes deve perpassar todo o 'ciclo de vida' da política, acompanhando seu nascimento, desenvolvimento, ajustes e transformações. Portanto, não basta que sejam transitórias. Por outro lado, sua flexibilidade, relativa independência em relação aos diferentes órgãos QUE articula, e capacidade de produzir decisões lastreadas no consenso parecem ser condições de sua dinamicidade e legitimidade. Este, sem dúvida, é um desafio à administração pública nacional.

Espera-se, primeiramente, que no decorrer deste trabalho tenham sido ao menos pontuadas algumas das questões a serem debatidas quanto à formulação e implementação de uma política de microfinanças que integra diferentes órgãos da administração pública, agentes públicos e privados para sua atuação coordenada: a origem dos recursos, a assunção de riscos, a repartição dos custos e receitas, a capacitação dos envolvidos na sua execução, a adoção de metodologias adequadas para que a finalidade de autosustentabilidade financeira do setor e os fins sociais últimos que inspiram a política sejam alcançados.

Em segundo lugar, ter firmado a posição de que as políticas microfinanceiras exigem o olhar especializado de diferentes órgãos da administração pública capazes de avaliar e promover os estímulos necessários, nas doses precisas, aos setores e agentes sob sua guarida. E isto não apenas por conta da heterogeneidade das entidades atuantes na prestação de serviços microfinanceiros, mas também por conta da complexidade da administração pública brasileira, e da sua legislação de regência que, abstratamente, traça linhas imaginárias delimitando o âmbito da atuação de seus múltiplos órgãos, atribuindolhes competências. Se a incidência de normas de caráter distinto sobre um mesmo fato por vezes faz surgir situações de contraposição e conflito, por vezes cria, também, situações de isolamento, em que o erro consiste na atuação isolada e cega da administração pública,

\footnotetext{
${ }^{114}$ N. K. Komesar, "Taking Institutional Choice Seriously", in Imperfect Alternatives: choosing institutions
} in law, economics and public policy, Chicago, University Chicago Press, 1994. 
num claro desperdício da oportunidade de conjugar a expertise dos seus olhares especializados sobre uma mesma realidade, sempre dinâmica e multifacetada. 


\section{CONSIDERACÕEES FINAIS}

Esta dissertação procurou contrapor o extenso arcabouço conceitual e regulatório das microfinanças a dados produzidos sobre a demanda por esses serviços no Brasil, sua oferta por diferentes agentes e recentes tentativas do governo federal em articular todo esse complexo conjunto a políticas públicas de superação da pobreza. Neste ponto, cabe retomar a incômoda pergunta presente no início da pesquisa: seria válida a hipótese de que o setor microfinanceiro não cresce por força da regulamentação existente no país?

Apesar de, à primeira vista, essa parecer uma pergunta dirigida ao direito, seus desdobramentos se estendem para muito além das apertadas fronteiras da análise jurídica. As etapas a serem percorridas na formulação de sua resposta esbarram em outras ciências, cujo instrumental por regra não é dominado pelos juristas. Este trabalho, ciente de suas limitações, procurou olhar para o conhecimento produzido por essas outras ciências sociais para, mesmo sem chegar a conclusões definitivas, compreender as implicações da pergunta formulada e as dificuldades da racionalidade formal do direito em apresentar respostas que sejam consistentes e críveis em face da complexidade das relações sociais e econômicas.

Assim, a partir da experiência brasileira, indaga-se da pertinência em traçar mapa das microfinanças no país que contemple, em um de seus extremos, as bancas comerciais, cuja atuação seria condicionada essencialmente pelo objetivo de lucro e não por uma finalidade social e inclusiva (a qual, não obstante, poderia derivar de sua atuação), em outro extremo instituições microfinanceiras de cunho social, sem fins lucrativos, comprometidas por demais com os interesses do seu público e fadadas a viver no limite do seu (des)equilíbrio financeiro e, por fim, ocupando zona intermediária, os bancos públicos, aparentemente aptos a buscar um ponto de equilíbrio entre os opostos.

Com base nesse mapa, seria o caso de reavaliar a existência de obstáculos jurídicos para apenas alguns específicos agentes, as instituições microfinanceiras desenvolvimentistas, destituídas de poder econômico e não apoiadas fundamentalmente no aparato público e nos seus recursos? Por fim, seriam esses obstáculos ou restrições em verdade normas protetivas, na medida em que impedem o surgimento de instituições 
desprovidas da capacitação e profissionalização necessárias para operacionalizar recursos junto ao público, ou mesmo inidôneas, i. e, representativas de risco à sua clientela?

A depender dos caminhos escolhidos para encontrar respostas a essas questões, pode se mesmo chegar à conclusão de que na verdade pouco importa o direito, e os controles prudenciais levados a cabo pelo Banco Central no país não seriam empecilho ao crescimento do setor, e sua evolução (ou involução) ocorreria a despeito desses mesmos controles, por questões outras atinentes à economia do país como um todo, aspectos sócioculturais, educacionais etc.

Como foi afirmado no decorrer da dissertação, não se pretende estabelecer relações de causalidade entre o estágio atingido pelas instituições microfinanceiras brasileiras e a sua regulação, a qual dá mostras, a cada nova norma editada, de buscar incessantemente um ponto de equilíbrio entre os dois modelos mais aceitos para a prestação de serviços microfinanceiros - ainda que diametralmente opostos - o minimalista $\mathrm{e} o$ desenvolvimentista. Até o momento, ao que parece, tal equilíbrio não foi atingido, na medida em que as cobranças dirigidas, em especial pelas entidades sem fins lucrativos, à autoridade reguladora pedem pelo aperfeiçoamento das normas às quais devem se submeter (ainda que indiretamente, por não integrarem o Sistema Financeiro Nacional) para alcançar os vultuosos recursos direcionados, por decisão governamental, às políticas de microcrédito.

No decorrer da pesquisa, percebeu-se a atuação do BCB concentrada fortemente nos mecanismos regulatórios voltados para a melhor alocação dos recursos entre as variadas categorias de agentes microfinanceiros, obedecidos os rígidos controles de higidez para essas instituições no Sistema Financeiro Nacional, bem como tornou-se evidente o papel do BNDES na consolidação da infra-estrutura do setor, por meio de seus planos de desenvolvimento institucional e de suas parcerias com o Ministério do Trabalho e Emprego no desenvolvimento de metodologias de avaliação e de planos de contas padronizados para entidades não reguladas no âmbito do Sistema Financeiro. Assim, ainda que submetidas a controles rígidos pela autoridade reguladora, as condições para o aperfeiçoamento dessas entidades são proporcionadas pelas políticas públicas direcionadas à indústria das microfinanças, e em particular por aquelas voltadas à disseminação do microcrédito como instrumento de geração de emprego e renda. 
Por fim, notou-se a clara intenção do Banco Central em acompanhar a evolução dos agentes microfinanceiros, avaliar seu amadurecimento institucional e realizar os ajustes necessários quanto à maior rigidez ou flexibilização das regras a que estão submetidos. Observou-se, no decorrer da pesquisa, que, apesar da existência de queixas e críticas, os debates que predominam nos principais fóruns de discussão sobre as microfinanças acabam, gradualmente e de acordo com os níveis de desempenho alcançados pelo setor, muito mais por estabelecer acordos do que dissensos, e a resultar em ganhos efetivos no plano regulamentar e institucional, ganhos esses até o momento favoráveis à construção das políticas públicas que esta dissertação procurou relatar. 


\begin{abstract}
Microfinance regulation should be understood as an integral part of a microfinance policy framework. In this sense, there was a recent acceleration in Brazil's microfinance sector from the end of the 1990s, due to a new political paradigms leading to a series of legal and regulatory changes favoring the expansion of microfinance. New regulatory initiatives and government policies have been adopted, many positive: policies related to the role of public and private financial institutions, and others related to income and education.
\end{abstract}

In this study, based largely on Banco Central do Brasil - BCB (Central Bank of Brazil) data, the following areas are examined in some depth: access to financial services, the importance of microcredit for the self-employed and for small entrepreneurs, the principles of good microfinance practice, institutional and legal framework, the multiple regulatory windows of Organizações da Sociedade Civil de Intereresse Público - OSCIPs (Public Interest Civil Societes) and Sociedades de Crédito ao Microempreendedor - SCMS (Microfinance Credit Societes), the substantial role of the regulatory authorities and of the public banks Banco do Nordeste do Brasil - BNB (North-east Bank) and Banco Nacional de Desenvolvimento Econômico e Social - BNDES (National Bank for Economic and Social Development). 


\section{BIBLIOGRAFIA}

ALVES, S. D. S., SOARES, M. M., Microfinanças - Democratização do crédito no Brasil - Atuação do Banco Central, $3^{\text {a }}$ ed., revista e ampliada. Brasília, Banco Central do Brasil, 2006.

, Microfinanças - O papel do Banco Central do Brasil e a importância do cooperativismo de crédito, $2^{\mathrm{a}}$ ed., revista e ampliada. Brasília, Banco Central do Brasil, 2007.

BANCO INTERAMERICANO DE DESENVOLVIMENTO, A politica das políticas públicas - Progresso econômico e social na América Latina: Relatório 2006, Banco Interamericano de Desenvolvimento e David Rockefeller Center for Latin American Studies, Harvard University, 2007, $2^{\mathrm{a}}$ reimpressão.

BIRCHALL, J. The international co-operative movement. Manchester, Manchester University Press, 1997.

BUCCI, M. P. D. “O conceito de política pública em direito”. In: BUCCI, M.P.D. (Org.). Políticas Públicas: reflexões sobre o conceito jurídico. São Paulo, Saraiva, 2007.

CARVAlHO, C. E. F., RIBEIRO C. T., Do microcrédito às microfinanças: desempenho financeiro, dependência de subsídios e fontes de financiamento, São Paulo, Fapesp, EDUC, 2006.

CHRISTEN, R. P., LYMAN, T. R., ROSENBERG, R., Microfinance consensus guidelines - guiding principles on regulation and supervision on microfinance, Washington, Consultative Group to Assist the Poor/The World Bank Group, 2003.

FERREIRA, W. M., Instituições de direito comercial, Primeiro volume: $O$ estatuto do comerciante e da sociedade comercial, $3^{\mathrm{a}}$ edição comemorativa do centenário do Código Comercial do Império do Brasil. Rio de Janeiro, Livraria Freitas Bastos S. A., 1951.

FIEBIG, M., HANNING, A., WISNIWSKI, S. "Savings in the context of microfinance state of knowledge". Consultative Group to Assist the Poor, 1999. 
HAUS, P. WINOGRAD, A. SALLES, R. A regulamentação do microcrédito, PDI/BNDES, 2002.

HELD, D. Models of democracy, $2^{\mathrm{a}}$ ed. Stanford, California, University Press, 1996.

KOMESAR, N. K., "Taking Institutional Choice Seriously", in Imperfect Alternatives: choosing institutions in law, economics and public policy, Chicago, University Chicago Press, 1994

KUMAR, A. Access to financial services in Brazil - Directions in Development. Washington DC, The World Bank, 2005.

LEDGERWOOD, J. WHITE, V. et alii. Transforming microfinance institutions Providing full financial services to the poor. Washington DC, The World Bank, 2006.

MIZRUCHI, M. S. STEARNS, L. B. "Money, banking and financial markets", in SMELSER, N. J. SWEDBERG, R. (editors). The Handbook of Economic Sociology. Princeton, Princeton University Press, 1994.

MONZONI, M. O impacto em renda do microcrédito, São Paulo, Editora Petrópolis, Centro de Estudos em Sustentabilidade - FGV-ESASP, 2008.

MOODY, J. C. FITE, Gilbert C. The credit union movement: origins and development 1850-1970. Lincon, University of Nebraska Press, 1971.

OGUS, A. "Corrective Taxes and Financial Impositions as Regulatory Instruments", in The Modern Law Review, v. 61, November, n. 6, 1998.

PARENTE, S. Microfinanças - saiba o que é um banco do povo, Brasília, Agência de Educação para o Desenvolvimento, 2002. 
ROCHA, J. P. C. V. A capacidade normativa de conjuntura no direito econômico: o déficit democrático da regulação financeira. Tese de doutorado apresentada à Faculdade de Direito da Universidade de São Paulo, 2004.

ROCHA, S. “Alguns aspectos relativos à evolução 2003-2004 da pobreza e da indigência no Brasil”, mimeo, janeiro de 2006.

ROSALES, R. Marco Jurídico para as instituições de microcrédito, BNDES/Microfinanças, 2000.

RUTHERFORD, S. The poor and their money. New Delhi: Oxford University Press, 2000.

SANTOS, A. C., GONÇALVES, M. E., MARQUES, M. M. L. Direito Económico, $2^{\mathrm{a}}$ ed., reimpressão, Coimbra: Livraria Almedina, 1997.

SEN, A. K., Desigualdade Reexaminada. Rio de Janeiro, Record, 2001.

SILVA, J. A. Comentário Contextual à Constituição, $2^{\mathrm{a}}$ ed. São Paulo, Malheiros, 2006.

SINGER, P. Introdução à economia solidária, $2^{\mathrm{a}}$ reimpressão. São Paulo, Editora Fundação Perseu Abramo, 2006.

SMELSER, N. J. SWEDBERG, R. "The sociological perspective on the economy", in SMELSER, N. J. SWEDBERG, R. (editors). The Handbook of Economic Sociology. Princeton: Princeton University Press, 1994.

SWEDBERG, R. "Markets as social structures". in SMELSER, N. J. SWEDBERG, R. (editors). The Handbook of Economic Sociology. Princeton: Princeton University Press, 1994. . Max Weber and the Idea of Economic Sociology. Princeton, Princeton University Press, 1998. 
WISNIWSKI, S. "Savings in the context of microfinance - Lessons Leanerd from Six Deposit-Taking Institutions”. Deustche Gesellschaft für Technische Zusammenarbeit, 1998.

YUNUS, M, JOLIS, A. O banqueiro dos pobres, $1^{\text {a }}$ edição, $10^{\mathrm{a}}$ impressão. São Paulo, Editora Ática, 2006. 